UNIVERSIDADE DE SÃO PAULO

FACULDADE DE ZOOTECNIA E ENGENHARIA DE ALIMENTOS

PRISCILA BREDARIOL

Controlar os parâmetros de assamento (tempo, temperatura, umidade) pode permitir a melhoria de algumas propriedades físicas e nutricionais de pães 
PRISCILA BREDARIOL

\title{
Controlar os parâmetros de assamento (tempo, temperatura, umidade) pode permitir a melhoria de algumas propriedades físicas e nutricionais de pães
}

\author{
Versão Corrigida
}

Dissertação apresentada à Faculdade de Zootecnia e Engenharia de Alimentos da Universidade de São Paulo, como parte dos requisitos para a obtenção do Título de Mestre em Ciências.

Área de Concentração: Ciências da Engenharia de Alimentos.

Orientadora: Prof ${ }^{a}$. Dr ${ }^{\mathrm{a}}$. Fernanda Maria Vanin. 
Ficha catalográfica elaborada pelo

Serviço de Biblioteca e Informação, FZEA/USP com os dados fornecidos pelo(a) autor(a)

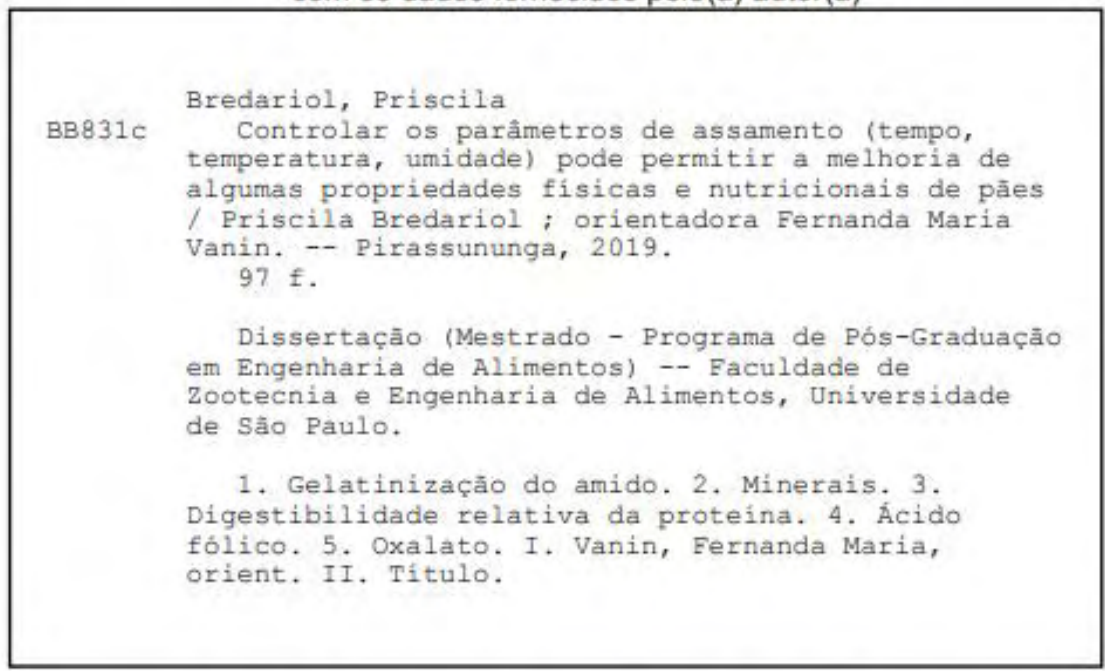

Permitida a cópia total ou parcial deste documento, desde que citada a fonte - o autor 


\section{PRISCILA BREDARIOL}

Controlar os parâmetros de assamento (tempo, temperatura, umidade) pode permitir a melhoria de algumas propriedades físicas e nutricionais de pães

Dissertação apresentada à Faculdade de Zootecnia e Engenharia de Alimentos da Universidade de São Paulo, como parte dos requisitos para a obtenção do Título de Mestre em Ciências.

Área de Concentração: Ciências da Engenharia de Alimentos.

Data de aprovação: 03/05/2019

\section{Banca examinadora:}

Prof $^{\mathrm{a}}$. Dr ${ }^{\mathrm{a}}$. Fernanda Maria Vanin

Instituição: FZEA - USP

Presidente da Banca Examinadora

Prof $^{\mathrm{a}}$. Dr ${ }^{\mathrm{a}}$. Anna Cecilia Venturini

Instituição: UNIFESP

Prof $^{\mathrm{a}}$. Dr ${ }^{\mathrm{a}}$. Cristiana Maria Pedroso Yoshida

Instituição: UNIFESP

Prof $^{\mathrm{a}}$. Dr ${ }^{\mathrm{a}}$. Vitor Augusto dos Santos Garcia

Instituição: USP 
Gostaria de dedicar este trabalho aos meus pais José Luiz Bredariol e Lourdes Felomena Manoel Bredariol, que me apoiaram durante todo o período do mestrado, pois sem eles não teria conseguido concluir este trabalho. 
Agradecimentos

Á minha família, José Luiz Bredariol, Lourdes Felomena Manoel Bredariol e Fabiana Bredariol por todo o apoio que recebi.

Á todos os membros e ex membros do Laboratório de Processamento de Pães e Massas (LAPROPAMA) que me auxiliaram na execução deste projeto.

Á técnica do laboratório Carla Alves Monaco Lourenço, assim como todos os técnicos e professores do Departamento de Engenharia de Alimentos da Universidade de São Paulo, que me forneceram suporte teórico durante o mestrado.

Á CAPES (001) pela bolsa de mestrado e a FAPESP (2013/12693-0; 2018/03324-5) pelo financiamento do projeto.

Á minha orientadora Professora Doutora Fernanda Maria Vanin que me forneceu as ferramentas necessárias para que eu conseguisse me desenvolver e com isso realizar uma boa pesquisa. 
BREDARIOL, P. Controlar os parâmetros de assamento (tempo, temperatura, umidade) pode permitir a melhoria de algumas propriedades físicas e nutricionais de pães. 2019. 97f. Dissertação (Mestrado) - Faculdade de Zootecnia e Engenharia de Alimento, Universidade de São Paulo, Pirassununga, 2019.

\section{RESUMO}

O pão é um dos alimentos mais consumidos em diversos países ao redor do mundo. Durante seu processamento, diversos parâmetros podem influenciar as características físicas do produto final, assim como os aspectos nutricionais. Os parâmetros de processo referem-se as diferentes variáveis envolvidas nas etapas de mistura da massa, fermentação e assamento dos pães, sendo esta última a etapa que representa os maiores custos enérgicos da produção. Dessa forma, o controle das condições de assamento como, tempo, temperatura e umidade relativa, podem permitir um controle das propriedades finais do produto, e ao mesmo tempo, otimizar os custos energéticos envolvidos na produção dos pães. Diante destes aspectos, o objetivo deste estudo foi avaliar o efeito dos parâmetros de tempo, temperatura e introdução de vapor na etapa de assamento sobre as propriedades tecnológicas e aspectos nutricionais do pão. Diferentes condições de assamento foram utilizadas a fim de produzir pães com características finais distintas. A avaliação tecnológica do pão foi determinada através das seguintes análises: aspectos visuais da crosta do pão, parâmetros de cor do miolo e da crosta, altura final do pão, perda de água durante o assamento, volume específico e análise de dureza do miolo. Análises de aquisição da temperatura local ao longo do assamento foram realizadas a fim de simular, posteriormente, a taxa de aumento de temperatura para cada condição avaliada durante as análises por calorimetria diferencial de varredura (DSC). Em relação aos nutrientes foi avaliada a estabilidade durante ao assamento para o ácido fólico e minerais, e a digestibilidade relativa da proteína, assim como a presença de oxalato. Os resultados indicaram que o aumento do tempo ou da temperatura e a introdução de vapor durante o início do assamento provocam mudanças tanto nas características físicas quanto nos aspectos nutricionais dos pães. A taxa de aquecimento aumentou com a elevação da temperatura de assamento, no miolo foi maior quando ocorreu adição de vapor, e para a crosta foi maior no assamento sem vapor. Mesmo apresentando diferentes taxas de aquecimento, algumas condições podem produzir pães com propriedades tecnológicas semelhantes, o que pode ser utilizado como uma estratégia na produção dos pães. Por outro lado, a gelatinização do amido foi única para cada condição de assamento. Quanto aos aspectos nutricionais, é possível preservar a estabilidade do ácido fólico e dos minerais assim como aumentar a digestibilidade da proteína ou ainda reduzir o teor de oxalato, realizando o controle do tempo, temperatura e umidade no forno durante o assamento. Logo, pode-se concluir que controlar os parâmetros de assamento (tempo, temperatura, umidade) permiti melhoria de algumas propriedades físicas e nutricionais de pães, a fim de obter pães com as características físicas desejadas e preservar a qualidade nutricional.

Palavras-chave: volume específico, perda de água, gelatinização do amido, minerais, digestibilidade relativa da proteína, ácido fólico, oxalato. 
BREDARIOL, P. Controlling the baking parameters (time, temperature, humidity) may allow the improvement of some physical and nutritional properties of breads. 2019. $97 \mathrm{f}$. M.Sc. Dissertation - Faculdade de Zootecnia e Engenharia de Alimento, Universidade de São Paulo, Pirassununga, 2019.

\begin{abstract}
Bread is one of the most consumed foods in many countries around the world. During its process, several parameters can influence the physical characteristics of the final products, as well as the nutritional aspects. The process parameters refer to the different variables involved in the stages of dough mixing, fermentation and bread baking, the latter being the step which represents the highest energy costs of production. In this way, the control of the baking conditions such as time, temperature and relative humidity can allow a control of the final bread properties and, at the same time, optimize the energy costs involved in the bread production. Therefore, the objective of this study was to evaluate the effect of baking parameters, time, temperature and steam introduction at the beginning of baking on the technological properties and nutritional aspects of bread. Different baking conditions were used in order to produce breads with distinct final characteristics. The technological evaluation of bread was determined through the following analyzes: visual aspects of bread crust, crust and crumb color parameters, final height of bread, water loss during baking, specific volume and crumb hardness. Local temperature acquisition along the baking were performed in order to simulate the rate of temperature increase for each condition evaluated during the analyzes by differential scanning calorimetry (DSC). In relation to nutrients, stability during baking was evaluated for folic acid and mineral, and the relative protein digestibility, as well as the presence of oxalate. The results indicated that the increase in time or temperature and the introduction of steam during the beginning of the baking cause changes in both the physical and nutritional aspects of breads. The heating rate increased with the elevation of the baking temperature; in the crumb, it was higher for baking with steam, and for the crust it was higher in the baking without steam. Even presenting different heating rates, some conditions can produce bread with similar technological aspects, which can be used as a strategy in the production of breads. On the other hand, starch gelatinization was unique for each baking condition. In relation to nutritional aspects, it is possible to preserve the stability of folic acid and minerals as well as to increase the digestibility of the protein or to reduce the content of oxalate, by controlling the time, temperature and humidity in the oven during the baking. Therefore, it could be concluded that, controlling the baking parameters (time, temperature, humidity) allows to improve some physical and nutritional properties of breads, in order to obtain breads with the desired physical characteristics and to preserve the nutritional quality.
\end{abstract}

Keywords: specific volume, water loss, starch gelatinization, minerals, relative protein digestibility, folic acid, oxalate. 


\section{LISTA DE FIGURAS}

Figura 1 - Fluxograma das etapas de processo envolvidas na produção do pão francês. 36

Figura 2 - Fluxograma referente as etapas de extração do ácido fólico nas amostras. 41

Figura 3 - Fluxograma referente aos procedimentos realizados para quantificar o ácido fólico presente na amostra.

Figura 4 - Fluxograma com a descrição dos procedimentos para determinação de oxalato nas amostras.

Figura 5 - $\quad$ Fluxograma com os procedimentos realizados para a padronização do oxalato.__44

Figura 6 - Procedimentos realizados para obtenção do controle (tempo zero). 45

Figura 7 - Fluxograma com os procedimentos realizados na etapa de digestibilidade das amostras. 45

Figura 8 - Avaliação do conteúdo de grupos de amino livre antes e depois da digestão das amostras. 46

Figura 9 - Temperaturas obtidas ao longo assamento medidas no miolo dos pães assados em diferentes temperaturas $\left(160^{\circ} \mathrm{C}, 190^{\circ} \mathrm{C}\right.$ e $\left.220^{\circ} \mathrm{C}\right) \mathrm{com}(\mathrm{CV})$ e sem $(\mathrm{SV})$ adição de vapor. _ 50 Figura 10 - Temperaturas obtidas ao longo do assamento na crosta dos pães assados em diferentes temperaturas $\left(160^{\circ} \mathrm{C}, 190^{\circ} \mathrm{C}\right.$ e $\left.220^{\circ} \mathrm{C}\right) \mathrm{com}(\mathrm{CV})$ e sem $(\mathrm{SV})$ adição de vapor.

Figura 11 - Aspectos visuais da crosta de pães assados sob diferentes condições de tempo $(9,12,15$ e $20 \mathrm{~min})$, temperatura $\left(160^{\circ} \mathrm{C}, 190^{\circ} \mathrm{C}\right.$ e $\left.220^{\circ} \mathrm{C}\right)$ e umidade no forno (com e sem introdução de vapor).

Figura 12 - Microscopia eletrônica de varredura com ampliação de 50x para os pães assados a 160,190 e $220^{\circ} \mathrm{C}$ durante $9,12,15$ e 20 minutos sem (SV) e com (CV) adição de vapor no início do assamento.

Figura 13 - Microscopia eletrônica de varredura com ampliação de 1500x para os pães assados a 160,190 e $220^{\circ} \mathrm{C}$ durante $9,12,15$ e 20 minutos sem (SV) e com (CV) adição de vapor no início do assamento. 


\section{LISTA DE TABELAS}

Tabela 1 - Efeito da temperatura (T) e tempo (t) de assamento de diferentes tipos de pães sobre os atributos de umidade, cor, textura e volume.

Tabela 2 - Quantidade de cada um dos ingredientes utilizados na produção do pão francês._34

Tabela 3 - Composição centesimal da farinha de trigo utilizada na produção dos pães. 48

Tabela 4 - Taxa de aquecimento na crosta e no miolo dos pães assados em diferentes temperaturas $\left(160^{\circ} \mathrm{C}, 190^{\circ} \mathrm{C}\right.$ e $\left.220^{\circ} \mathrm{C}\right)$ com e sem adição de vapor.

Tabela 5 - Resultados de luminosidade L* do miolo dos pães assados com e sem introdução de vapor nas temperaturas de 160,190 e $220^{\circ} \mathrm{C}$, para os tempos de 9, 12, 15 e 20 minutos.

Tabela 6 - Resultados de luminosidade $L^{*}$ da crosta dos pães assados com e sem introdução de vapor nas temperaturas de 160,190 e $220^{\circ} \mathrm{C}$, para os tempos de $9,12,15$ e 20 minutos.

Tabela 7 - Resultados de croma $a^{*}$ do miolo dos pães assados com e sem introdução de vapor nas temperaturas de 160,190 e $220^{\circ} \mathrm{C}$, para os tempos de $9,12,15$ e 20 minutos.

Tabela 8 - Resultados de croma $\mathrm{a}^{*}$ da crosta dos pães assados com e sem introdução de vapor nas temperaturas de 160,190 e $220^{\circ} \mathrm{C}$, para os tempos de $9,12,15$ e 20 minutos.

Tabela 9 - Resultados de croma $b^{*}$ do miolo dos pães assados com e sem introdução de vapor nas temperaturas de 160,190 e $220^{\circ} \mathrm{C}$, para os tempos de $9,12,15$ e 20 minutos.

Tabela 10 - Resultados de croma $b^{*}$ da crosta dos pães assados com e sem introdução de vapor nas temperaturas de 160,190 e $220^{\circ} \mathrm{C}$, para os tempos de $9,12,15$ e 20 minutos.

Tabela 11 - Resultados da altura final $(\mathrm{cm})$ dos pães assados com e sem introdução de vapor nas temperaturas de 160,190 e $220^{\circ} \mathrm{C}$, para os tempos de $9,12,15$ e 20 minutos.

Tabela 12 - Resultados da perda de água (gramas de água/100 gramas de pão) em relação a massa inicial dos pães assados com e sem introdução de vapor nas temperaturas de 160, 190 e $220^{\circ} \mathrm{C}$, para os tempos de $9,12,15$ e 20 minutos.

Tabela 13 - Resultados do volume específico (ml/g) dos pães assados com e sem introdução de vapor nas temperaturas de 160,190 e $220^{\circ} \mathrm{C}$, para os tempos de $9,12,15$ e 20 minutos. 
Tabela 14 - Resultados da dureza $(\mathrm{kg})$ dos pães assados com e sem introdução de vapor nas temperaturas de 160,190 e $220{ }^{\circ} \mathrm{C}$, para os tempos de $9,12,15$ e 20 minutos.

Tabela 15 - Efeito do tempo, temperatura e umidade do forno sobre as respostas de cor, altura, perda de água, volume especifico e dureza dos pães.

Tabela 16 - Condições de assamento (tempo e temperatura) para os tratamentos com (CV) e sem (SV) introdução de vapor, que fornecem respostas semelhantes para volume especifico, dureza e perda de água.

Tabela 17 - Primeira temperatura onset (To1) para o miolo e para a crosta dos pães em cada taxa de aquecimento avaliada e condição de assamento simulada $\left(160,190\right.$ e $220^{\circ} \mathrm{C}$; sem (SV) e com (CV) introdução de vapor).

Tabela 18 - Segunda temperatura onset (To2) para o miolo e para a crosta dos pães em cada taxa de aquecimento avaliada e condição de assamento simulada $\left(160,190\right.$ e $220^{\circ} \mathrm{C}$; sem (SV) e com (CV) introdução de vapor).

Tabela 19 - Entalpia de gelatinização do amido para o miolo e para a crosta dos pães em cada taxa de aquecimento avaliada e condição de assamento simulada $\left(160,190\right.$ e $220^{\circ} \mathrm{C}$; sem (SV) e com (CV) introdução de vapor).

Tabela 20 - Ácido fólico ( $\mu \mathrm{g}$ ácido fólico/100g amostra) para a farinha de trigo, massa após a mistura dos ingredientes e massa após a fermentação.

Tabela 21 - Ácido fólico ( $\mu$ g ácido fólico/100g amostra) para cada condição de tempo (9, 12,15 e $20 \mathrm{~min}$ ), temperatura $\left(160^{\circ} \mathrm{C}, 190^{\circ} \mathrm{C}\right.$ e $220^{\circ} \mathrm{C}$ ) e introdução (ou não) de vapor durante o assamento dos pães.

Tabela 22 - Teor de macro e microminerais (mg/100g de pão liofilizado) encontrados nas amostras de pão francês para cada condição de tempo (9, 12, 15 e 20 min) e temperatura (160, 190 e $220^{\circ} \mathrm{C}$ ) no assamento sem introdução de vapor.

Tabela 23 - Teor de macro e microminerais (mg/100g de pão liofilizado) encontrados nas amostras de pão francês para cada condição de tempo (9, 12, 15 e 20 min) e temperatura (160, 190 e $220^{\circ} \mathrm{C}$ ) no assamento com introdução de vapor.

Tabela 24 - Oxalato (mg/100g de extrato) para cada condição de tempo (9, 12, 15 e 20 min), temperatura $\left(160,190\right.$ e $220^{\circ} \mathrm{C}$ ) e introdução (ou não) de vapor durante o assamento dos pães. 84 
Tabela 25 - Digestibilidade relativa da proteína (\%) para cada condição de tempo $(9,12,15$ e $20 \mathrm{~min}$ ), temperatura $\left(160^{\circ} \mathrm{C}, 190^{\circ} \mathrm{C}\right.$ e $220^{\circ} \mathrm{C}$ ) e introdução (ou não) de vapor durante o assamento dos pães.

Tabela 26 - Efeito do tempo, temperatura e umidade no forno sobre as respostas de ácido fólico, macro e micronutrientes, oxalato e digestibilidade relativa da proteína nos pães. 
3.1. Propriedades físicas

3.2. Nutrientes __ 22

3.2.1. Ácido fólico___ 22

3.2.2. Minerais 23

3.2.3. Oxalato — 25

3.3. Tratamento térmico ___ 25

3.3.1. Gelatinização parcial do amido__ 25

3.3.2. Desnaturação das proteínas___ 27

3.3.3. Atividade das enzimas no pão___ 28

3.3.4. Reação de Maillard __ 29

3.3.5. Compostos voláteis __ 29

3.3.6. Formação e expansão dos gases ___ 31

3.3.7. Introdução de vapor no assamento ___ 31

4. MATERIAL E MÉTODOS

4.1. Materiais ____ 33

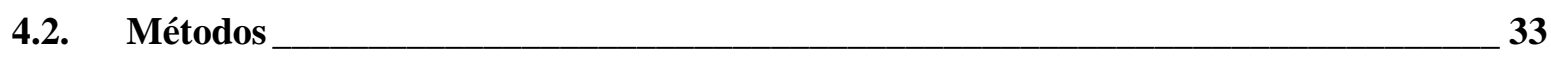

4.2.1. Composição centesimal da farinha ___ 33

4.2.2. Produção do pão __ 34

4.2.3. Aquisição da temperatura local ao longo do assamento ___ 37

4.2.4. Avaliação das propriedades físicas dos pães___ 37

4.2.4.1 Aspectos visuais da crosta do pão___ 37

4.2.4.2 Parâmetros de cor __ 37

4.2.4.3 Altura final do pão ___ 37

4.2.4.4 Perda de água durante o assamento___ 38

4.2.4.5 Volume específico ___ 38

4.2.4.6 Análise de dureza __ 38

4.2.5. Análise do miolo do pão utilizando microscopia eletrônica de varredura (MEV)___ 38

4.2.6. Gelatinização dos grãos de amido____ 39

4.2.7. Análise da estabilidade dos nutrientes___ 39

4.2.7.1. Preparo das amostras ___ 39 
4.2.7.2. Ácido fólico _ 40

4.2.7.3. Minerais __ 42

4.2.7.4. Oxalato __ 42

4.2.7.5. Digestibilidade relativa da proteína __ 44

4.2.8. Análise estatística __ 47

5. RESULTADOS E DISCUSSÃO

5.1. Composição Centesimal da farinha de trigo ___ 48

5.2. Aquisição da temperatura local ao longo do assamento ___ 49

5.3. Avaliação das propriedades físicas dos pães ___ 52

5.3.1. Aspectos visuais da crosta do pão ___ 52

5.3.2. Parâmetros de cor _ 54

5.3.3. Altura __ 62

5.3.4. Perda de água durante o assamento ___ 63

5.3.5. Volume específico__ 64

5.3.6. Análise de dureza __ 66

5.3.7. Resumo dos efeitos ___ 67

5.3.8. Otimização do processo de assamento __ 68

5.4. Análise do miolo do pão por microscopia eletrônica de varredura (MEV) _ 70

5.5. Gelatinização dos Grãos de Amido____ 73

5.6. Análise da estabilidade dos nutrientes ___ 77

5.6.1. Ácido fólico___ 77

5.6.2. Minerais _ 79

5.6.3. Oxalato __ 83

5.6.4. Digestibilidade relativa da proteína____ 85

5.6.5. Resumo dos efeitos ___ 86

6. 


\section{INTRODUÇÃO}

O pão é um produto amplamente consumido por toda população nas diferentes regiões do mundo (AHRNÉ et al., 2007). O consumo anual varia consideravelmente de país para país, no Brasil o consumo é de 34,09kg por ano para cada brasileiro (ABIP, 2014), enquanto que no Chile, Argentina, Peru e Paraguai os valores são de 93,0kg, $73 \mathrm{~kg}, 32 \mathrm{~kg}$ e $23 \mathrm{~kg}$, respectivamente (ABIP, 2012). Segundo pesquisa realizada pelo Instituto Tecnológico de Panificação e Confeitaria - ITPC (2017) e pela ABIP (ABIP, 2017) o mercado de panificação e confeitaria gerou um faturamento de $\mathrm{R} \$$ 87,24 bilhões e um crescimento de 3,08\% em 2016, já as vendas de produtos que foram fabricados pelas próprias panificadoras apresentou um crescimento equivalente a $11,2 \%$.

Os fatores que influenciam a aceitação do pão francês são principalmente a textura e a cor, devido à presença de uma crosta crocante de cor castanha (ALTAMIRANO-FORTOUL et al., 2012). A formulação é um dos fatores que influenciam a aceitação do produto, uma vez que modificam as propriedades sensoriais do pão. Um excesso de absorção de água irá fornecer uma massa pegajosa e isto prejudicará a fermentação (PYLER, E. J; GORTON, 2008). O sal além de realçar o sabor do pão também tem uma função importante na regulação da fermentação, facilita a manipulação da massa por meio de modificações em sua reologia (SALOVAARA, 1982) e aumenta sua vida de prateleira, uma vez que ajuda a evitar a transferência de água do pão para o ambiente (PYLER, E. J; GORTON, 2008).

Além da formulação, as condições de processo também influenciam as propriedades sensoriais e devem ser cuidadosamente analisadas em todas as etapas de produção. Por exemplo, a etapa de assamento do pão francês é um processo complexo, onde ocorre o aquecimento e o transporte de água, processos necessários para as reações de Maillard e caramelização do açúcar (AHRNÉ et al., 2007). No caso de produtos de panificação, no assamento, a reação de Maillard (de natureza não enzimática) entre os grupos carbonila e amino, é responsável pelo desenvolvimento de uma ampla gama de cor, odores e sabores que tornam o produto atraente (O’BRIEN; MORRISSEY; AMES, 1989).

A etapa de assamento dos pães também requer uma demanda elevada de energia, devido ás temperaturas empregadas (entre $160^{\circ} \mathrm{C}$ a $250^{\circ} \mathrm{C}$ ) e o uso do vapor (LE-BAIL et al., 2010). A introdução de vapor no início do assamento proporciona a formação de uma 
superfície úmida e flexível capaz de suportar rápida expansão da massa, e permite a precipitação de elementos voláteis que formam uma crosta crocante de cor castanha (AMENDOLA; REES, 2003). Logo, para manter a qualidade sensorial e otimizar o processo produtivo dos pães, é importante um adequado controle dos parâmetros de tempo, temperatura, umidade relativa do ar e taxa de calor durante o assamento (AHRNÉ et al., 2007).

Outro fator importante a ser considerado durante o assamento é o valor nutricional do produto. $\mathrm{O}$ pão francês contém compostos nutricionais básicos e importantes para a nutrição humana como, por exemplo, os carboidratos que são responsáveis pelo fornecimento de energia (VASCONCELOS et al., 2006), e as proteínas, que possuem componentes com funções hormonais e estruturais, que dão origem aos anticorpos e participam do processo de regulação metabólica (MAIHARA et al., 2006). A velocidade com que estes componentes são digeridos e absorvidos pelo organismo depende de diversos fatores, como por exemplo, a quantidade de carboidratos/proteínas presentes no alimento, assim como a composição do amido/proteína. A estabilidade dos carboidratos é influenciada pelas etapas de processamento e assamento em que o alimento é submetido (CAPRILES; GUERRA-MATIAS; ARÊAS, 2009; WOLEVER et al., 1991).

Além desses componentes majoritários, o pão contém ainda ácido fólico, minerais e outros micronutrientes. O ácido fólico é uma vitamina pertencente ao grupo dos folatos, sendo a forma mais estável deste grupo, porém não está disponível no corpo humano em sua forma natural. O ácido fólico é reduzido, no organismo humano, pelo processo de hidrogenação dando origem ao di-hidrofolato e ao tetrahidrofolato (BALUZ; CARMO; ROSAS, 2002). Segundo Santos e Pereira (2007) durante o início do período de gestação, mais especificamente entre a $3^{\mathrm{a}}$ e a $5^{\mathrm{a}}$ semana, é possível ocorrer má-formação das estruturas que serão responsáveis pelo desenvolvimento do cérebro e da medula espinhal, porém, a suplementação com ácido fólico evita que isso ocorram (SANTOS; PEREIRA, 2007). Uma dosagem diária superior a $5 \mathrm{mg}$ de ácido fólico é capaz de reduzir em até $91 \%$ dos defeitos no tubo neural (WALD et al., 2001). Por este motivo, todas as farinhas de trigo produzidas no Brasil devem receber adição de 140 a $220 \mu \mathrm{g}$ de ácido fólico a cada $100 \mathrm{~g}$ de produto ANVISA (2017).

Adicionalmente, o trigo, componente principal na produção dos pães, assim como outros cereais, é rico em minerais, os quais devem estar presentes na alimentação humana, uma vez que exercem diversas funções, como por exemplo, auxiliam no sistema imune, no 
crescimento, na maturação sexual e no desenvolvimento neuromotor (BUENO; CZEPIELEWSKI, 2007). Fideles; Osório, (2007) realizaram uma pesquisa com crianças do estado de Pernambuco e constataram que existe uma deficiência dos micronutrientes, principalmente nas áreas rurais do estado. Um estudo, realizado pela Faculdade de Ciências Farmacêutica da Universidade de São Paulo constatou que a deficiência em micronutrientes atinge aproximadamente 2 milhões de pessoas. Também ressaltou que a anemia é uma das piores complicações enfrentadas pelos brasileiros, causada devido à falta de ferro, e destacou também a deficiência de outros compostos como a vitamina A, zinco e selênio. O mesmo trabalho revela ainda que o consumo diário de cálcio está em torno de 300 a 500mg, valor muito abaixo do recomendado (1000mg por dia). O magnésio também é consumido em quantidades inferiores em algumas regiões do país e o ferro apresenta baixa biodisponibilidade, quanto ao zinco, o consumo é baixo, principalmente para idosos (COZZOLINO, 2007).

Adicionalmente, os cereais possuem agentes antinutricionais que atuam como inibidores dos nutrientes presentes no alimento (GUPTA; NAGAR, 2014). O oxalato é um exemplo de antinutriente presente em diversos tipos de pães, entre 16,5 a 45,9 mg/100g de acordo com o tipo de pão avaliado (OKOMBO; LIEBMAN, 2010), e que pode atuar na inibição de alguns minerais, como por exemplo o ferro (SOTELO et al., 2010) e o cálcio (KENNEFICK; CASHMAN, 2000). O oxalato se liga a estes minerais impedindo que estes sejam utilizados pelo corpo (SOTELO et al., 2010).

Apesar de existirem estudos que avaliaram a presença destes componentes no pão, poucas pesquisas têm avaliado como as condições de processo, mais especificamente como os parâmetros do assamento, podem influenciar nas propriedades físicas e na degradação e/ou formação de compostos e nutrientes. Portanto, este trabalho teve como objetivo avaliar como os parâmetros de tempo, temperatura e introdução de vapor durante o assamento podem influenciar as características físicas e a estabilidade de alguns nutrientes e antinutriente presentes no pão francês. 


\section{OBJETIVO}

O objetivo principal deste projeto foi avaliar o efeito das condições do processo de assamento (tempo, temperatura e umidade) nas propriedades tecnológicas do pão francês (cor, altura final do pão, percentual de perda de água, volume e textura) e na estabilidade de alguns nutrientes, assim como na formação de antinutrientes.

Alguns objetivos específicos foram:

- Produzir pães assados durante 9, 12, 15 e 20 minutos a 160,190 e $220^{\circ} \mathrm{C}$ com e sem introdução de vapor;

- Avaliar a estrutura dos pães em nível microscópico;

- Avaliar as propriedades tecnológicas;

- Avaliar a gelatinização do amido;

- Determinar a digestibilidade relativa da proteína;

- Quantificar os compostos ácido fólico, minerais e oxalato. 


\section{REVISÃO BIBLIOGRÁFICA}

Uma pesquisa sobre estudos relacionados ao processamento de pães e avaliação das propriedades tecnológicas e nutricionais foi realizada a fim de verificar o estado da arte relacionado aos efeitos do processamento nas diversas propriedades finais de pães, ou seja, em como os parâmetros de tempo, temperatura e introdução de vapor durante o assamento podem influenciar na melhoria das propriedades físicas e nutricionais, ou ainda na degradação dos compostos nutricionais ou indesejáveis.

\subsection{Propriedades físicas}

Os parâmetros tecnológicos do pão francês como umidade, volume específico, textura e cor são definidos durante a etapa de assamento. Estes fatores determinam a qualidade sensorial deste alimento. A Tabela 1 apresenta trabalhos reportados na literatura que investigaram diferentes condições de assamento sobre alguns parâmetros tecnológicos dos pães.

A umidade do pão pode ser reduzida com maior ou menor intensidade dependendo das condições de tempo, temperatura e vapor aplicadas durante o assamento. Os resultados obtidos por Izadi Najafabadi et al. (2014) em pães Sangak demonstram que a temperatura e o tempo de assamento contribuem para a redução da umidade durante o assamento. Segundo Shittu et al. (2007) a temperatura tem maior influência sobre a umidade do que o tempo, porém para Sui et al. (2015) o tempo de assamento reduziu a umidade e a temperatura não exerceu influencia. É importante explicar que Shittu et al. (2007) comparou tempos de assamento do pão de mandioca entre 20 e 40 minutos com temperaturas entre 190 e $240^{\circ} \mathrm{C}$, enquanto que Sui et al. (2015) avaliou o assamento de pães fortificados com antocianina a cada 2 minutos pelo tempo máximo de 12 minutos com temperaturas de 200,220 e $240^{\circ} \mathrm{C}$. Por meio destes resultados, pode-se induzir que, no início do assamento, até 12 minutos, os pães perdem muita água e, por isso, é verificado uma redução na umidade com o aumento do tempo de assamento. Por outro lado, para os pães que permaneceram por longos períodos no forno, a perda de água é reduzida e a umidade dos pães entre 20 e 40 minutos tende a ser constante, sendo mais predominante o efeito da elevação da temperatura. É importante ressaltar também que, a perda de água ocorre com maior intensidade na crosta do que no 
miolo. Park and Baik (2007) verificaram que a umidade no miolo do pão Francês permaneceu constante entre 3 a 20 minutos de assamento à $218^{\circ} \mathrm{C}$. Izadi Najafabadi et al. (2014) produziram pães Sangak em três condições diferentes de assamento $\left(280^{\circ} \mathrm{C} / 8 \mathrm{~min} ; 310^{\circ} \mathrm{C} /\right.$ 5,5 min e $340^{\circ} \mathrm{C} / 4 \mathrm{~min}$ ) e constataram que a condição que melhor preserva a umidade foi a com maior temperatura e menor tempo, ou seja, $340^{\circ} \mathrm{C}$ por 4 minutos, reforçando assim o efeito do tempo no teor de umidade do produto final. Quanto a introdução de vapor durante o assamento, Mondal e Datta (2009) constataram que este exerce pouca influência sobre a umidade de pães sem crosta quando o assamento ocorre em baixas temperaturas $(160,170$ e $\left.180{ }^{\circ} \mathrm{C}\right)$ durante longos tempos (35, 30 e 25 minutos).

Em relação aos parâmetros de cor, segundo Shittu et al., (2007) tanto a elevação da temperatura quanto o aumento do tempo de assamento provocam mudanças na cor de pães de mandioca, devido a formação de pigmentos oriundos das reações que ocorrem na massa durante o assamento, como, por exemplo, a reação de Maillard. Quando ocorre a elevação da temperatura, de 200 para $240^{\circ} \mathrm{C}$, os valores de saturação $\mathrm{C}^{*}$ aumentam como resultado de um escurecimento ou até mesmo queima da crosta dos pães fortificados com antocianina (SUI; YAP; ZHOU, 2015). Segundo Erbas et al. (2012) trabalhar com temperaturas menores $\left(200^{\circ} \mathrm{C}\right)$ por maiores tempos de assamento (25 minutos), fornece maiores valores de luminosidade e de croma $b^{*}$ em pães com metabissulfito de sódio, por outro lado, os valores de croma a* são menores. Quanto a elevação do tempos de assamento (de 3 para 20 min), para temperaturas de $218^{\circ} \mathrm{C}$, ocorre a redução dos valores de luminosidade e o aumento da intensidade da cor amarela e vermelha do pão Francês, porém, após 12 minutos de assamento a cor amarela começa a reduzir (Park e Baik 2007). Em relação a introdução de vapor durante a assamento, Mondal e Datta (2009) verificaram que este fator influencia os parâmetros de cor de pão sem crosta porém, com menor intensidade do que a temperatura e o tempo de assamento. Ahrné et al. (2007) constataram que a temperatura na crosta do pão branco é reduzida quando o assamento ocorre com introdução de vapor, o que permite trabalhar com elevadas temperaturas $\left(260^{\circ} \mathrm{C}\right)$ e obter pães com características de cor aceitáveis, o mesmo tratamento sem introdução de vapor apresentou aspectos de crosta queimada. 
Tabela 1 - Efeito da temperatura $(\mathrm{T})$ e tempo $(\mathrm{t})$ de assamento de diferentes tipos de pães sobre os atributos de umidade, cor, textura e volume.

\begin{tabular}{|c|c|c|c|c|}
\hline \multicolumn{2}{|c|}{ Produto / atributo avaliado } & \multirow{2}{*}{$\begin{array}{c}\text { Condições de Assamento } \\
\text { T: } 200,220 \text { e } 240^{\circ} \mathrm{C} ; \\
\text { t: } 0,2,4,6,8,10 \text { e } 12 \text { min }\end{array}$} & \multirow{2}{*}{$\begin{array}{c}\text { Resultado } \\
\text { sstante para todas as T } \\
\uparrow \mathrm{t} \downarrow \text { umidade }\end{array}$} & \multirow{2}{*}{$\begin{array}{c}\text { Referência } \\
\text { Sui; Yap; Zhou (2015) }\end{array}$} \\
\hline \multirow{5}{*}{ 莺 } & Pão fortificado com antocianina & & & \\
\hline & Pão Sangak & $\begin{array}{c}\mathbf{T}: 280,310 \text { e } 340^{\circ} \mathrm{C} \\
\quad \mathbf{t}: 8,5,5 \text { e } 4 \mathrm{~min}\end{array}$ & T e t influenciam a umidade & Izadi Najafabadi et al. (2014) \\
\hline & Pão sem crosta & $\begin{array}{l}\text { T: } 160,170 \text { e } 180^{\circ} \mathrm{C} \\
\text { t: } 25,30 \text { e } 35 \mathrm{~min} \\
\text { Vapor: } 6,8 \text { e } 10 \mathrm{~min}\end{array}$ & $\begin{array}{l}\text { Influência forte para todos os } \\
\text { tratamentos }\end{array}$ & Mondal; Datta (2011) \\
\hline & Pão Francês & $\begin{array}{c}\mathbf{T}: 218^{\circ} \mathrm{C} \\
\mathbf{t}: 3,6,9,12,15 \text { e } 20 \text { min }\end{array}$ & $\uparrow \mathrm{t}=$ umidade constante no miolo & Park; Baik (2007) \\
\hline & Pão de mandioca & $\begin{array}{c}\text { T: } 190 \text { a } 240^{\circ} \mathrm{C} \\
\text { t: } 20 \text { a } 40 \text { min. }\end{array}$ & $\mathrm{T}$ influenciou mais que $\mathrm{t}$ & Shittu; Raji; Sanni (2007) \\
\hline \multirow{3}{*}{$\dot{\ddot{\theta}}$} & Pão fortificado com antocianina & $\begin{array}{c}\mathbf{T}: 200,220 \text { e } 240^{\circ} \mathrm{C} \\
\mathbf{t}: 0,2,4,6,8,10 \text { e } 12 \mathrm{~min} .\end{array}$ & $\downarrow \mathrm{T}=\downarrow \mathrm{C} *$ & Sui; Yap; Zhou (2015) \\
\hline & Pão com metabissulfito de sódio & $\begin{array}{l}\mathbf{T}: 200,230 \text { e } 250^{\circ} \mathrm{C} \\
\text { t: } 25,20 \text { e } 15 \mathrm{~min} .\end{array}$ & $\downarrow \mathrm{T}:>\mathrm{L}^{*} \mathrm{e} \mathrm{b}^{*},<\mathrm{a}^{*}$ & Erbas et al. (2012) \\
\hline & Pão sem crosta & $\begin{array}{c}\text { T: } 160,170 \text { e } 180{ }^{\circ} \mathrm{C} \\
\text { t: } 25,30 \text { e } 35 \mathrm{~min} ; \\
\text { Vapor: } 6,8 \text { e } 10 \mathrm{~min}\end{array}$ & Vapor tem $<$ influência do que o $\mathrm{T}$ e $\mathrm{t}$ & Mondal; Datta (2011) \\
\hline
\end{tabular}




\begin{tabular}{|c|c|c|c|c|}
\hline \multicolumn{2}{|r|}{ Produto / atributo avaliado } & \multirow{2}{*}{$\begin{array}{c}\text { Condições de Assamento } \\
\text { T: } 200,230 \text { e } 260^{\circ} \mathrm{C} \\
\text { t: } 15,12 \text { e } 10 \text { min; } \\
\text { Introdução de vapor. }\end{array}$} & Resultado & \multirow[b]{2}{*}{ Ahrné et al. (2007) } \\
\hline & Pão branco & & $\begin{array}{c}\downarrow \text { de temperatura na crosta e cor } \\
\text { aceitável }\end{array}$ & \\
\hline & Pão Francês & $\begin{array}{c}\mathbf{T}: 218^{\circ} \mathrm{C} \\
\mathbf{t}: 3,6,9,12,15 \text { e } 20 \mathrm{~min} .\end{array}$ & $\begin{array}{c}\uparrow \mathrm{t}(\mathrm{de} 3 \operatorname{para} 20 \min )=\downarrow \mathrm{L}^{*} \mathrm{e} \uparrow \mathrm{a}^{*} \\
\mathrm{t}<12 \uparrow \mathrm{b}^{*} \mid \mathrm{t}>12 \downarrow \mathrm{b}^{*}\end{array}$ & Park; Baik (2007)) \\
\hline & Pão de mandioca & $\begin{array}{l}\text { T: } 190 \text { a } 240^{\circ} \mathrm{C} \\
\text { t: } 20 \text { a } 40 \mathrm{~min}\end{array}$ & $\begin{array}{l}\uparrow \mathrm{T} \text { e } \mathrm{t} \text { intensificaram a formação de } \\
\text { pigmentos }\end{array}$ & Shittu; Raji; Sanni (2007) \\
\hline \multirow{3}{*}{ 苞 } & Pão Sangak & $\begin{array}{l}\mathbf{T}: 280,310 \text { e } 340^{\circ} \mathrm{C} \\
\mathbf{t}: 8,5,5 \text { e } 4 \text { min; }\end{array}$ & $\uparrow$ dureza para $>$ t e baixas $\mathrm{T}$ & Izadi Najafabadi et al. (2014) \\
\hline & Pão sem crosta & $\begin{array}{l}\text { T: } 160,170,180^{\circ} \mathrm{C} \\
\text { t: } 25,30 \text { e } 35 \mathrm{~min} ; \\
\text { Vapor: } 6,8 \text { e } 10 \mathrm{~min}\end{array}$ & $\begin{array}{l}\text { todos influenciam a força de } \\
\text { cisalhamento. }\end{array}$ & Mondal; Datta (2011) \\
\hline & Pão de mandioca & $\begin{array}{l}\text { T: } 190 \text { a } 240^{\circ} \mathrm{C} \\
\text { t: } 20 \text { a } 40 \text { min. }\end{array}$ & $\uparrow \mathrm{t}=>$ dureza. & Shittu; Raji; Sanni (2007) \\
\hline \multirow{3}{*}{$\stackrel{巳}{\Xi}$} & Pão com metabissulfito de sódio & $\begin{array}{l}\text { T: } 200,230 \text { e } 250^{\circ} \mathrm{C} \\
\text { t: } 25,20 \text { e } 15 \mathrm{~min} .\end{array}$ & Constante para todos os tratamentos & Erbas et al. (2012) \\
\hline & Pão Francês & $\begin{array}{c}\mathbf{T}: 218^{\circ} \mathrm{C} \\
\mathbf{t}: 3,6,9,12,15 \text { e } 20 \mathrm{~min} .\end{array}$ & Constante após $6 \min$ a $218^{\circ} \mathrm{C}$ & Park; Baik (2007) \\
\hline & Pão de mandioca & $\begin{array}{l}\text { T: } 190 \text { a } 240^{\circ} \mathrm{C} \\
\text { t: } 20 \text { a } 40 \text { min. }\end{array}$ & $\begin{array}{c}\uparrow \text { volume }=\uparrow \mathrm{T} \\
\uparrow \text { volume }=\downarrow \mathrm{t}\end{array}$ & Shittu; Raji; Sanni (2007) \\
\hline
\end{tabular}

Fonte: Próprio autor, 2019. 
Quanto aos parâmetros que definem a textura do pão, segundo Shittu et al. (2007) a dureza do pão de mandioca está relacionada com o teor de água presente no pão, um aumento no tempo de assamento, de 20 para 40 minutos, aumentou a perda de água e consequentemente, os pães apresentaram maior dureza. Izadi Najafabadi et al. (2014) trabalharam com três condições de assamento $\left(280^{\circ} \mathrm{C} / 8\right.$ minutos; $310^{\circ} \mathrm{C} / 5,5$ minutos e $340^{\circ} \mathrm{C} / 4$ minutos) e constataram que diferentes condições de assamento (temperatura/tempo) fornecem diferentes propriedades de firmeza para o pão Sangak. Sendo que, uma maior dureza foi obtida para o assamento utilizando a menor temperatura e o maior tempo. Além disso, Mondal e Datta (2009) também verificaram que, assim como a temperatura e o tempo, a introdução de vapor no forno durante o assamento também é importante para definir a dureza do pão sem crosta.

Para o volume específico, Shittu et al. (2007) constataram um aumento deste parâmetro em pães de mandioca assados a temperaturas mais altas $\left(240^{\circ} \mathrm{C}\right)$ e tempos menores (20 minutos), em relação ao tratamento a $190^{\circ} \mathrm{C}$ por 40 minutos. Sendo assim, quando desejase obter maiores volumes é mais aconselhável utilizar elevadas temperaturas em menores tempos. Em relação a elevação do tempo de assamento, segundo Park and Baik (2007), à temperatura de $218^{\circ} \mathrm{C}$, o volume do pão Francês torna-se constante após 6 minutos de assamento. Em adição, Erbas et al., (2012) verificaram que não há diferença significativa para o volume do pão com metabissulfito de sódio quando o tratamento ocorre nas seguintes condições: $200^{\circ} \mathrm{C} / 25$ minutos; $230^{\circ} \mathrm{C} / 20$ minutos e $250^{\circ} \mathrm{C} / 15$ minutos.

Finalmente, pode-se verificar que os pães podem ser produzidos sob diferentes condições de tempo, temperatura e introdução ou não de vapor e cada condição de assamento fornece características específicas em relação as propriedades de umidade, cor, textura e volume. Dessa forma, evidencia-se a necessidade de estudos destinados a melhor compreensão dos efeitos das condições de assamento dos pães sobre as características do produto final. Além disso, observa-se que são escassos os estudos que procuraram avaliar o efeito de diferentes condições de assamento na manutenção das propriedades físicas do produto final. 


\subsection{Nutrientes}

Diversos componentes nutricionais estão presentes no pão, alguns agregam valor nutritivo ao produto e outros podem funcionar como antinutrientes. Muitos destes compostos não são estáveis durante o processamento e podem reduzir ou aumentar de acordo com as condições de assamento utilizadas. A seguir estão apresentados alguns componentes presentes no pão francês e a sua estabilidade durante o assamento.

\subsection{1. Ácido fólico}

A degradação térmica do ácido fólico, também conhecido como vitamina $\mathrm{B}_{9}$, ocorre em soluções ácidas, com pH abaixo de 4 (MARGARET I. B. DICK, 1947). A temperatura de $250^{\circ} \mathrm{C}$ ocorre sua decomposição (ALABURDA; SHUNDO, 2007).

A deficiência de ácido fólico pode causar problemas para a saúde, como por exemplo, defeitos do tubo neural em bebês (CZEIZEL; DUDÁS, 1992). Com a intenção de reduzir doenças, no Brasil, em 2002, a adição de $150 \mu \mathrm{g}$ de ácido fólico em $100 \mathrm{~g}$ de farinha de trigo tornou-se obrigatória, segundo os critérios definidos pelo Ministério da Saúde por meio da legislação RDC 344 de 13 de dezembro de 2002 (MINISTÉRIO DA SAÚDE, 2002). Em 2017 a ANVISA modificou este valor para 140 a $220 \mu \mathrm{g}$ de ácido fólico em 100g de farinha de trigo ANVISA (2017).

Existem diversos tipos de pães, como por exemplo, pão francês, pão de forma, baguetes, pão de hambúrguer, pão sem crosta, entre outros. Cada tipo exige uma sequência de processamento específica. As diferentes condições de processo podem contribuir ou não para a estabilidade dos compostos, por isso, os alimentos processados têm quantidades de folato, variáveis de acordo com os processos de preparação aos quais foram submetidos. Segundo Osseyi et al. (2001), as etapas de fermentação e assamento podem causar retenção do folato. No caso do assamento, a perda de água e a elevação da taxa de aquecimento podem provocar a degradação de alguns compostos nutricionais (ANDERSON et al., 2010).

Verificou-se que existem poucos estudos disponíveis na literatura sobre a avaliação da estabilidade do ácido fólico durante a etapa de assamento. Osseyi; Wehling; Albrecht (2001) avaliaram a estabilidade e distribuição de ácido fólico durante as diferentes etapas de 
produção de pães. A farinha utilizada foi enriquecida com tiamina, riboflavina, niacina, ferro e ácido fólico. Neste trabalho foi realizado o monitoramento por cromatografia líquida de alta eficiência (CLAE) em diferentes fases da panificação com adição de ácido fólico e folatos nativos. A perda total de ácido fólico entre a farinha e o pão pronto foi estimada em 20\% (em peso seco), para pães assados a $218^{\circ} \mathrm{C}$ durante 25 minutos. No estudo realizado por Anderson et al. (2010) constataram-se que diferentes tipos de pães (pães brancos, integral e baguetes) podem sofrer maior ou menor degradação de ácido fólico durante o assamento, provavelmente devido as diferentes etapas de produção. Além disso, estes autores concluíram que outros fatores afetam a degradação do ácido fólico como a perda de água da massa e a taxa de aquecimento durante o assamento. Da mesma forma, Gujska; Majewska (2005) avaliaram o efeito do processo de assamento e da adição de ácido ascórbico na estabilidade de ácido fólico e seus endógenos folatos, em pães fabricados com farinha de trigo e com farinha de centeio. Os autores observaram que o teor de ácido fólico diminuiu na etapa de assamento $\left(230^{\circ} \mathrm{C} / 30\right.$ minutos), concluindo que a adição de ácido ascórbico ao processamento de pão não aumentou a retenção de folatos nativos e ácido fólico no pão.

Desta forma, existem diversos fatores que podem interferir na estabilidade do ácido fólico e verifica-se, portanto, a necessidade de estudar as condições de assamento para compreender seus efeitos sobre a estabilidade do ácido fólico presente nos pães.

\subsubsection{Minerais}

Os cereais podem fornecer um aumento significativo na quantidade de nutrientes disponíveis para a população humana (MURPHY; REEVES; JONES, 2008). O magnésio, por exemplo, está presente em muitos alimentos de origem vegetal (ROSANOFF, 2013). A farinha de trigo contém em média 31mg de magnésio para cada 100 gramas de farinha (NEPA - NÚCLEO DE ESTUdOS E PESQUISAS EM ALIMENTAÇÃO, 2011), porém sua concentração no trigo tem sido reduzida desde 1968 devido à utilização de variedades de alto rendimento (BULDINI; CAVALLI; TRIFIRO, 1997). A redução do magnésio e outros nutrientes essenciais na dieta pode causar aumento da obesidade e da taxa de mortalidade devido a doenças cardiovasculares (ROSANOFF, 2013). Apesar de sua importância, até o presente momento do estudo, não foram encontrados na literatura trabalhos que avaliaram a estabilidade deste nutriente durante o assamento. 
Além do magnésio, outros minerais presentes em produtos de panificação são de extrema importância para a saúde humana. Por exemplo, cálcio e fósforo, assim como o magnésio, são responsáveis pela integridade óssea esquelética (BULDINI; CAVALLI; TRIFIRO, 1997). Além disso, o cálcio exerce diversas outras funções, como ativação de enzimas, regulação do sistema nervoso e muscular e coagulação sanguínea (KŁOBUKOWSKI1; SKIBNIEWSKA2; KOWALSKI, 2014). Apesar de sua importância, o consumo de cálcio está abaixo do recomendado (COZZOLINO, 2007). Além disso, o consumo médio de sódio é cinco vezes superior ao recomendado, o que pode provocar interferências quanto ao aproveitamento do cálcio pelo organismo (COZZOLINO, 2007).

O zinco exerce diversas funções, relacionadas a cicatrização de feridas, adaptação a ambientes escuros e crescimento. A deficiência em zinco pode causar sintomas como falta de apetite, diarreia, alterações na pele e infecções (WALSH et al., 1994). Apesar dos benefícios, a presença de zinco em grandes quantidades pode também estar associado a síndrome de Down e a insuficiência renal crônica (COZZOLINO, 2007).

O selénio, por sua vez, exerce função antioxidante e atua no metabolismo da glândula tireoide, porém, em grande quantidade, pode causar quedas de unha e cabelo, irritabilidade, fadiga, infertilidade e aborto (COZZOLINO, 2007). A deficiência de ferro pode causar anemia, por outro lado, o excesso de ferro também pode ser prejudicial, causando danos no tecido e fibrose (ANDREWS, 1999).

Alguns trabalhos na literatura avaliaram o efeito da adição de diferentes ingredientes na formulação de pães sobre o conteúdo de minerais. Tuncel et al. (2014) avaliaram o efeito da adição de farelo de arroz no pão e Abdualrahman et al. (2017) quantificaram o teor de minerais de pães kissra. Wronkowska et al. (2015) produziram pães com diferentes concentrações de farinha de centeio e verificaram o efeito sobre os nutrientes. A bioacessibilidade dos minerais também foi avaliada em relação a presença de diferentes formas de ferro (REBELLATO et al., 2017). Porém, nenhum destes artigos avaliaram o efeito das condições de assamento sobre a estabilidade dos minerais.

Deste modo, quantificar os níveis de minerais em produtos de panificação e sua degradação durante o assamento pode representar uma importante estratégia para a indústria, a fim de preservar os minerais presentes em seus produtos e contribuir com a saúde dos consumidores. 


\subsubsection{Oxalato}

Leal el al. (2010) estudaram o efeito do fator antinutricional oxalato, sobre a disponibilidade de metais ferro e zinco. Foi concluído que o oxalato pode impedir a absorção destes minerais, mesmo quando está presente em pequena quantidade.

Os produtos derivados da farinha de trigo podem ser fonte de oxalato, porém, devido à diferentes ingredientes utilizados na formulação e também à diversidade de tipos de farinhas existentes no mercado, o teor de oxalato nestes produtos é muito variável (OKOMBO; LIEBMAN, 2010).

Okombo; Liebman (2010) avaliaram a presença de oxalato em diferentes tipos de pães adquiridos no mercado local. Foi detectado a presença de oxalato nos pães, variando de 16,5 a 45,9 mg/ $100 \mathrm{~g}$ de produto dependendo do tipo de pão. Porém, não foram avaliados como os parâmetros de processamento podem influenciar na possível degradação do oxalato. Também, não foi encontrado nenhum estudo relacionado a degradação do oxalato durante a etapa de produção do pão.

\subsection{Tratamento térmico}

Durante a etapa de assamento ocorrem diversas modificações na estrutura do pão, como por exemplo gelatinização parcial do amido, desnaturação das proteínas presentes na massa, formação da crosta, expansão do volume, formação do aroma e sabor característico (PYLER, E. J; GORTON, 2008).

\subsubsection{Gelatinização parcial do amido}

A gelatinização do amido pode ser definida como o processo de desagregação (ZANONI; SCHIRALDI; SIMONETTA, 1995) ou inchamento (LUND; LORENZ, 1984) dos grânulos de amido que ocorre na presença de água em uma temperatura específica e de maneira irreversível (LUND; LORENZ, 1984; ZANONI; SCHIRALDI; SIMONETTA, 1995). 
Os grânulos de amido presentes na farinha de trigo são compostos por dois polissacarídeos, amilopectina e amilose. A estrutura das moléculas de amilopectina consiste em uma parte ramificada e uma linear, esta última forma estruturas helicoidais duplas que são estabilizadas por pontes de hidrogênio entre grupos hidroxila e dão origem às regiões cristalinas dos grânulos. A cadeia de amilose e a região ramificada da amilopectina formam a região amorfa (KEETELS; OOSTERGETEL; VAN VLIET, 1996). A gelatinização do amido causa o rompimento da organização molecular e mudanças irreversíveis nas suas propriedades (SOUZA; ANDRADE, 2000), provocando modificações na textura (FU et al., 2018) e no volume final do pão (VERBAUWHEDE et al., 2018).

Para controlar as mudanças que ocorrem em alimentos com amido em sua composição, como é o caso do pão, é necessário compreender como as propriedades físicas são afetadas pela taxa de aquecimento e temperatura empregadas durante o aquecimento (MALUMBA et al., 2013).

A gelatinização do amido ocorre durante o assamento (VERBAUWHEDE et al., 2018). Uma parte dos grânulos de amido absorvem água livre (GISSLEN, 1895; PYLER, E. J; GORTON, 2008), na temperatura de aproximadamente $40^{\circ} \mathrm{C}$ começam a inchar (PYLER, E. J; GORTON, 2008). Na faixa de temperatura entre 50 a $65{ }^{\circ} \mathrm{C}$ ocorre a degradação enzimática e como consequência tem-se modificações das propriedades viscoelásticas da massa (PYLER, E. J; GORTON, 2008) e o aumento da firmeza dos pães (GISSLEN, 1895).

A temperatura utilizada durante o assamento é um fator que determina a gelatinização do amido. Uma elevação na temperatura de assamento dos pães, de $220^{\circ} \mathrm{C}$ para $240^{\circ} \mathrm{C}$, reduz a capacidade de gelatinização dos grânulos de amido (BESBES et al., 2013). Caso a taxa de aquecimento seja muito lenta, as endotermas podem se deslocar fornecendo temperaturas de gelatinização menores (DONOVAN;REGIONAL, 1979).

A introdução de vapor durante o assamento também é uma fator determinante para a gelatinização do amido na crosta (BESBES et al., 2013). O vapor reduz a taxa de aquecimento na superfície do pão, uma vez que, parte da energia que seria demandada para aquecer o produto deve ser utilizada para evaporar a água condensada na superfície oriunda do vapor adicionado (LE-BAIL et al., 2011).

A gelatinização do amido ocorre no miolo do pão (BESBES et al., 2013) e deve ser completa para que se tenha o assamento completo do produto (CHHANWAL et al., 2010). Já 
na crosta, é necessário uma maior demanda de energia para remover a água ligada e ocorrer a gelatinização (BESBES et al., 2013).

Existem diversos estudos na literatura que avaliaram a gelatinização do amido (Biliaderis et al., 1980; Donovan, 1979; Ratnayake et al., 2009; Rouillé et al., 2010; Schirmera et al., 2011). Porém, poucos trabalhos estudaram a gelatinização do amido no pão e os que avaliaram (Rouillé et al., 2010; Schirmera et al., 2011) trabalharam com outras condições de processo, ou seja, pães assados e armazenados congelados antes da análise e avaliados com excesso de água. Portanto, os estudos sobre a gelatinização de amido durante o assamento e o efeito da taxa de aquecimento sobre a temperatura e entalpia de gelatinização são escasso e devem ser melhor avaliados.

\subsubsection{Desnaturação das proteínas}

A desnaturação das proteínas provoca alterações nas estruturas secundárias, terciárias e quaternárias (SCHMIELE et al., 2017), além disso, também ocorre o rompimento das ligações de hidrogênio (LUO et al., 2018).

Este processo ocorre durante o tratamento térmico (NEILL; AL-MUHTASEB; MAGEE, 2012), quanto a temperatura da massa do pão está entre 60 e $85^{\circ} \mathrm{C}$ (MONDAL; DATTA, 2008). Na faixa de temperatura de 60 a $70^{\circ} \mathrm{C}$ as proteínas perdem sua capacidade de aprisionar a água, tornando-a disponível para a gelatinização (PYLER, E. J; GORTON, 2008). Elevando um pouco mais a temperatura $\left(74^{\circ} \mathrm{C}\right)$ os filmes de glúten localizados ao redor da célula de gás interagem com o amido inchado e pela ação do calor ocorre a desnaturação dos filmes de glúten, dando origem a uma estrutura semirrígida (PYLER, E. J; GORTON, 2008).

Assim como a desnaturação da proteína pode contribuir com a estrutura ela também é importante para manter a sustentação do volume do pão. A flexibilidade dos grânulos de amido dentro da célula é aumentada conforme as células de gás expandem fazendo com que o filme de glúten apresente uma estrutura muito fina (PYLER, E. J; GORTON, 2008). 


\subsubsection{Atividade das enzimas no pão}

As enzimas podem ser encontradas nos alimentos de maneira natural ou serem adicionadas na formulação (ZHANG et al., 2017a). As enzimas presentes naturalmente na farinha de trigo são a amilases, proteases, lipoxigenase, polifenoloxidase e peroxidase (VIDAL et al., 2016). É também comum adicionar enzimas na formulação da farinha, pois fornecem diversos benefícios tecnológicos, como por exemplo, facilitam a manipulação da massa (TEBBEN; SHEN; LI, 2018), fornecem maior hidratação, uma vez que as enzimas contribuem com a hidrólise dos polímeros (OLAERTS; VANDEKERCKHOVE; COURTIN, 2018), contribuem com a expansão do volume aumentando a atividade fermentativa das leveduras, reduzem o endurecimento e fornecem benefícios nutricionais (TEBBEN; SHEN; LI, 2018).

Apesar de seus benefícios para a panificação, durante o processo de assamento do pão a atividade das enzimas pode sofrer alterações devido à elevação da temperatura (ZHANG et al., 2017a). A cada elevação de $10^{\circ} \mathrm{C}$ na temperatura de assamento a capacidade de hidrólise do amido realizada pela amilase duplica. No início do assamento a atividade da amilase contribui com a expansão da massa promovendo uma maior fluidez, também ocorre a elevação da taxa de maltose e dextrina. A temperatura de $50{ }^{\circ} \mathrm{C}$ a $\alpha$-amilase fúngica está em sua condição mais ativa e quando a temperatura atinge $60{ }^{\circ} \mathrm{C}$, é inativada. Entre 57 a $72{ }^{\circ} \mathrm{C}$ ocorre a inativação da $\beta$-amilase de uma maneira muito rápida (PYLER, E. J; GORTON, 2008).

Além da temperatura, existem diversos outros fatores que afetam a atividade enzimática como pH, concentração enzimática (TEBBEN; SHEN; LI, 2018), microestrutura do pão e conteúdo de umidade (Zhang et al., 2017a).

Devido a estes fatores, a inativação da enzima pode variar de acordo com a localização no pão. Ocorre mais intensamente no miolo do que na crosta, o que indica que a microestrutura mais densa na crosta preserva a atividade enzimática, ou ainda, que o maior conteúdo de umidade no miolo favorece a inativação das enzimas (Zhang et al., 2017a).

É necessário controlar a concentração de enzimas presentes na massa, uma vez que, quando em excesso, podem fornecer cor indesejável para a crosta, através da redução da luminosidade e saturação da cor vermelha (BARBOSA-RÍOS et al., 2018). 


\subsubsection{Reação de Maillard}

Maillard é uma reação de escurecimento não enzimática (BERTRAND et al., 2018) que ocorre em três estágios (início, avançado e final) (PASTORIZA; QUESADA; RUFIANHENARE, 2018) na presença de açúcares redutores, entre os grupos amino de aminoácidos e os grupos carbonila (PATRIGNANI et al., 2019) dando origem a polímeros denominados melanoidinas (BERTRAND et al., 2018).

Esta reação é a principal responsável pela formação da cor (AHRNÉ et al., 2007) aroma e do sabor dos pães (MILDNER-SZKUDLARZ et al., 2017; O'BRIEN; MORRISSEY; AMES, 1989). A concentração de açúcar (PÉREZ-BURILLO; RUFIÁN-HENARE; PASTORIZA, 2018; SHEN; CHEN; LI, 2018), o conteúdo de proteína (PÉREZ-BURILLO; RUFIÁN-HENARE; PASTORIZA, 2018) e a presença de amido (SHEN; CHEN; LI, 2018) são fatores importantes para que a reação de Maillard ocorra. Além disso, as condições de assamento também afetam a reação (MILDNER-SZKUDLARZ et al., 2017; TAVARES et al., 2018) devido a taxa de aquecimento e o transporte água (AHRNÉ et al., 2007). Quando a temperatura de ebulição da água é alcançada e ocorre a interação entre os açúcares redutores livres com os grupos amina de aminoácidos, peptídeos ou proteínas ocorre a reação da Maillard (PYLER, E. J; GORTON, 2008).

A atividade enzimática também está relacionada com a intensidade da reação de Maillard. Uma alta taxa de atividade enzimática fornece mais açúcares redutores para serem utilizados na reação de Maillard (OLAERTS; VANDEKERCKHOVE; COURTIN, 2018). Outros fatores que interferem na reação são o pH, (BERTRAND et al., 2018) a presença de lipídeo, o conteúdo de umidade presente no pão (TAVARES et al., 2018), e a atividades da $\alpha$-amilase durante a etapa de fermentação da massa (OLAERTS; VANDEKERCKHOVE; COURTIN, 2018).

\subsubsection{Compostos voláteis}

O aroma característico do pão é definido pelos compostos voláteis presentes na massa (PÉTEL; ONNO; PROST, 2017). Os principais compostos voláteis presentes no pão são ácidos, alcoóis, aldeídos, cetonas, ésteres, furanos, hidrocarbonetos, pirazinas e pirróis (PACYNSKI; WOJTASIAK; MILDNER-SZKUDLARZ, 2015). 
Na etapa de fermentação ocorre a formação de compostos voláteis, como o dióxido de carbono e o etanol, devido a ação das leveduras presentes na massa. Os açúcares e aminoácidos também exercem importante função na formação de compostos voláteis durante o assamento do pão (PÉTEL; ONNO; PROST, 2017).

Devido à elevada temperatura presente no forno, durante o assamento é possível aumentar a quantidade de compostos voláteis presentes na massa (PÉTEL; ONNO; PROST, 2017), ou dar origem a um novo composto, como é o caso do 2-pentilfurano, encontrado apenas no pão após o assamento (PICO et al., 2017).

Os compostos voláteis são formados tanto na região da crosta como no miolo do pão e durante a formação da crosta pode ocorrer migração dos compostos entre estas regiões (PICO; BERNAL; GÓMEZ, 2015). A maioria dos compostos fenólicos presentes no miolo do pão são formados na etapa de fermentação (IZZREEN; HANSEN; PETERSEN, 2016). Alguns compostos presentes no miolo possuem baixo ponto de ebulição e por isso podem ser evaporados durante o assamento, como é o caso do 2,3-butanodiona, 1-propanol, 2-metil-1propanol, 3-metil-1-butanol e 2-metil-1-butanol (PICO et al., 2017). Na crosta do pão, os compostos voláteis são formados principalmente devido às reações de Maillard e oxidação lipídica (IZZREEN; HANSEN; PETERSEN, 2016).

Após o final do assamento, enquanto o pão fica em temperatura ambiente, ocorre à perda dos componentes que formam o aroma e sabor doce e após 96 horas o sabor azedo é intensificado (PYLER, E. J; GORTON, 2008).

É importante salientar ainda que, a elevada concentração de um determinado composto volátil no pão não está diretamente relacionada com a melhor percepção sensorial pelo consumidor. Alguns compostos presentes em baixa concentração podem ser facilmente percebidos pelo consumidor enquanto que outros, mesmo em grande quantidade, podem não ser sensorialmente identificados (PICO; BERNAL; GÓMEZ, 2015). 


\subsubsection{Formação e expansão dos gases}

Os gases presentes na massa dão origem a região porosa presente no miolo do pão (GALLY et al., 2016). O dióxido de carbono é o principal componente responsável pela fermentação e também está presente no assamento com adição de vapor (GISSLEN, 1895). Além disso, a formação dos gases contribui para o aumento do volume do pão (GRENIER; RAY; LUCAS, 2010). Se o assamento ocorrer em temperaturas muito altas o pão pode apresentar pouco volume devido a gelatinização ter ocorrido antes da expansão do gás (GISSLEN, 1895).

Durante a fermentação ocorre a formação de dióxido de carbono devido a ações de leveduras presentes na massa (GALLY et al., 2016; VERHEYEN et al., 2015). A qualidade dos ingredientes utilizados na formulação também pode contribuir ou prejudicar a expansão da massa. Diferentes farinhas, produzidas com diferentes cultivares de trigo, podem fornecer massas com propriedades reológicas distintas. Massas que apresentam baixa deformabilidade podem ter menor expansão das células de gás durante a fermentação e assamento e com isso menor volume final do pão (SLIWINSKI; KOLSTER; VAN VLIET, 2004).

As proteínas do glúten são importantes para manter os gases presentes na massa, pois formam uma rede que os aprisionam assim que são formados e expandidos, assim é possível obter uma boa fermentação e uma massa leve (GISSLEN, 1895).

\subsubsection{Introdução de vapor no assamento}

A presença de vapor no forno é uma etapa muito importante e deve ser adicionado durante os primeiros minutos de assamento. Ao longo do processo a água deve ser evaporada para que assim seja mantido o nível de umidade atmosférica adequado (AHRNÉ et al., 2007).

A introdução de vapor provoca a redução da temperatura na crosta (AHRNÉ et al., 2007) com isso a taxa líquida de evaporação é reduzida (LE-BAIL et al., 2011; PYLER, E. J; GORTON, 2008) e consequentemente o conteúdo de umidade, textura (PYLER, E. J; GORTON, 2008), espessura e luminosidade da crosta e o peso do pão também sofrem mudanças (DEBONNE et al., 2017). Além disso, o vapor preserva a extensibilidade da superfície da massa e a penetração do calor dentro da massa (PYLER, E. J; GORTON, 2008), 
também fornece um ambiente com temperaturas mais adequadas para que as leveduras atuem no início do assamento (LE-BAIL et al., 2011).

No início do assamento, em um ambiente com umidade saturada, a massa do pão absorve uma pequena quantidade de água até que a temperatura da superfície atinge o ponto de orvalho e então inicia-se a formação da crosta. O conteúdo de umidade da crosta é reduzido em cerca de 5\%, uma parte da água migra para o interior do pão e condensa, assim não há uma grande alteração na umidade do miolo na etapa de assamento. Depois que o pão sai do forno a evaporação da água continua. Após esfriar o pão atingir 38\% de água (PYLER, E. J; GORTON, 2008). 


\section{MATERIAL E MÉTODOS}

\subsection{Materiais}

Para a produção dos pães franceses foi utilizado farinha de trigo (FT) (Suprema), melhorador químico (S500, Puratos), sal (Cisne) e fermento biológico fresco (Fleischmann) adquirido no comércio local de Pirassununga, São Paulo, alguns dias antes de ser utilizado e armazenado em geladeira.

Para análise de extrato etéreo utilizou-se éter anidro, na quantificação do ácido fólico foi utilizado fosfato de sódio, acetonitrila e padrão ácido fólico. Para a digestibilidade proteica foram utilizados solução tampão fosfato salina $\left(\mathrm{NaCl} ; \mathrm{Na}_{2} \mathrm{HPO}_{4} ; \mathrm{NaH}_{2} \mathrm{PO}_{4} \times \mathrm{H}_{2} \mathrm{O}\right)$, hidróxido de sódio, ácido clorídrico, pancreatina, ácido trinitrobenzenosulfonico $(0,1 \%)$ e tampão fosfato de sódio $\left(\mathrm{NaH}_{2} \mathrm{PO} ; \mathrm{Na}_{2} \mathrm{HPO}_{4}\right)$. E para a avaliação de oxalato utilizaram-se ácido sulfúrico e permanganato de potássio. Todos os reagentes e padrão foram adquiridos da empresa Sigma.

\subsection{Métodos}

\subsubsection{Composição centesimal da farinha}

O teor de umidade (U) foi determinado pelo método 925,10 (AOAC, 1980) pela secagem de 2 gramas de amostra de farinha em estufa a $105^{\circ} \mathrm{C}$, com circulação de ar forçada até atingir peso constante.

O teor de proteína bruta $\left(\mathrm{P}_{\mathrm{b}}\right)$ foi determinado pelo método Ba4f-00 (AOCS, 2009) através da determinação do teor de nitrogênio total, utilizando o sistema completo para determinação de nitrogênio/proteína por combustão (Loco FP, modelo 528, EUA).

O teor de cinzas (C) pelo método 923,03 (AOAC, 1995) por meio da incineração de 5 gramas de amostra em mufla a $550^{\circ} \mathrm{C}$ até atingir a cor branca.

Para a determinação de extrato etéreo $\left(\mathrm{E}_{\mathrm{e}}\right)$ foi utilizada o método 920,39 (AOAC, 1995), a extração de 2 gramas de amostras, previamente secas, ocorreu com éter anidro em 
um extrator Soxhlet, sob aquecimento suficiente para fornecer uma taxa de condensação de 5 a 6 gotas por segundo, durante 6 horas. Após este período o resíduo extraído foi seco em estufa a $100^{\circ} \mathrm{C}$ até atingir peso constante. A perda no peso representou o teor de extrato etéreo.

A fração glicídica (FG) foi calculada por diferença de acordo com a Eq. 1, expresso em g. $100 \mathrm{~g}^{-1}$.

$$
F G=100-\left(U+P_{b}+C+E_{e}\right)
$$

\subsubsection{Produção do pão}

Para a produção dos pães foram utilizados os ingredientes de acordo com as quantidades descritas na Tabela 2.

Tabela 2 - Quantidade de cada um dos ingredientes utilizados na produção do pão francês.

\begin{tabular}{lcc}
\hline Ingredientes & Quantidades (gramas) & Concentração (\%) \\
\hline Farinha de trigo & 1200 & 100 \\
Água & 696 & 58 \\
Fermento & 60 & 5 \\
Sal & 24 & 2 \\
Melhorador & 12 & 1 \\
\hline Massa total obtida & 1992 &
\end{tabular}

Fonte: Adaptado de Vanin et al. (2010).

Foi realizado o controle da temperatura da água a partir das temperaturas do laboratório e da farinha de acordo com a Eq. 2. A temperatura de referência adotada foi de $60^{\circ} \mathrm{C}$ e a água não ultrapassou $35^{\circ} \mathrm{C}$, temperatura máximo adequada.

$$
\mathrm{T}_{\text {água }}=\mathrm{T}_{\text {ref }}-\left(\mathrm{T}_{\text {labo }}+\mathrm{T}_{\text {farinha }}\right) \text {. }
$$

Primeiramente a farinha de trigo foi adicionada em uma amassadeira espiral (Famag Brasil, AM12E), em seguida adicionaram-se os outros ingredientes secos (melhorador e sal) o fermento (diluído em água) e por último a água. Os ingredientes foram misturados por um 
período de 9 minutos. Em seguida a massa foi boleada, coberta por um plástico filme e permaneceu em repousou por 10 minutos. Então, foi dividida em pedaços de 100 gramas, boleada novamente, coberta por um plástico filme e repousou por mais 15 minutos. Após este período a massa passou por uma modeladora (Prática Technipan, MR500) para adquirir o formato de pão francês, foi então levada à estufa (Klimaquip, $\mathrm{CF}-20$ ) a $35^{\circ} \mathrm{C}$ e $80 \%$ de umidade relativa até atingir 2,5 vezes o seu volume inicial. Também foram adicionadas na estufa 25 gramas de massa em um pote plástico utilizado para medir o crescimento da massa. Após a fermentação, foi realizado o corte da pestana em todos os pães. A última etapa do processamento foi o assamento em um forno industrial (Prática Technipan, E250) durante 9, 12 , 15 e 20 minutos utilizando-se 3 temperaturas diferentes $\left(160^{\circ} \mathrm{C}, 190^{\circ} \mathrm{C}\right.$ e $\left.220^{\circ} \mathrm{C}\right)$ com e sem adição de vapor durante os 10 primeiros segundos de assamento. Os parâmetros de assamento foram definidos de acordo com as condições de assamento utilizadas na literatura, como demonstrado na Tabela 1 (seção 3.1) A Figura 1 apresenta o fluxograma referente as etapas de processamento do pão francês. 
Figura 1 - Fluxograma das etapas de processo envolvidas na produção do pão francês.

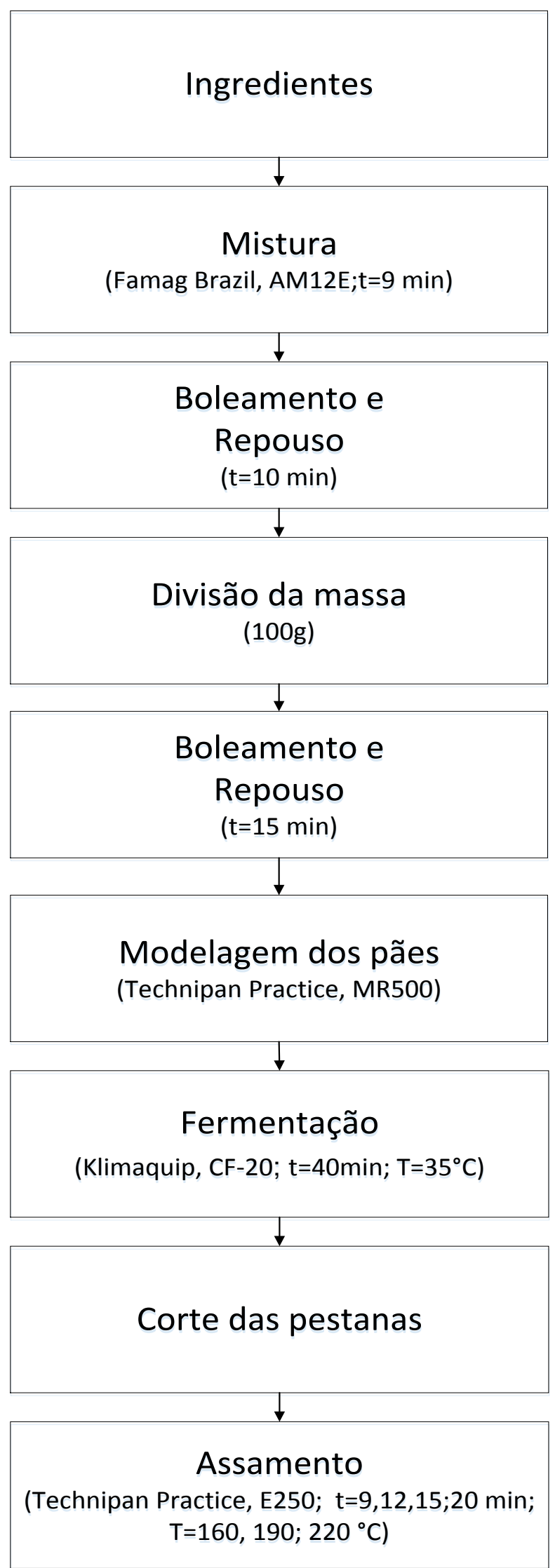

Fonte: Próprio autor, 2019. 


\subsubsection{Aquisição da temperatura local ao longo do assamento}

Determinado de acordo com a metodologia descrita por Vanin et al. (2010). A temperatura do centro (miolo) e da superfície (crosta) do pão foi monitorada ao longo de todo o processo de assamento utilizando um termopar calibrado (tipo T, $\varnothing_{1 / 4}$ 0,2 mm) acoplado a uma central de aquisição de dados (Keysight Technologies, 34972A). Os dados foram adquiridos a cada 10 segundos e um gráfico relacionando temperatura e tempo de assamento foi plotado a fim de obter a evolução cinética da temperatura local durante o processo. A taxa de aquecimento foi então calculada pela relação entre temperatura e tempo, no ponto em que a temperatura se manteve constante. Para cada condição de assamento obteve-se uma taxa de aquecimento específica e está foi utilizada como parâmetro de velocidade de elevação da temperatura na análise de calorimetria diferencial de varredura (DSC).

\subsubsection{Avaliação das propriedades físicas dos pães}

\subsubsection{Aspectos visuais da crosta do pão}

As imagens da crosta dos pães foram obtidas uma hora após o assamento utilizado-se uma câmera fotográfica (Nikon D3400) .

\subsubsection{Parâmetros de cor}

Determinados de acordo com a metodologia descrita por Lara et al. (2011). A análise de cor do miolo e da crosta dos pães foi realizada utilizando o colorímetro (Hunterlab, Miniscan XE plus) com a escala CIELab. Sendo que, L* representa a luminosidade da amostra, croma $\mathrm{a}^{*}$ representa a intensidade da cor vermelho/verde e o croma $\mathrm{b}^{*}$ a intensidade da cor amarelo/azul. Selecionou-se a luz do dia como o iluminante e o observador a $10^{\circ}$.

\subsubsection{Altura final do pão}

Determinada de acordo com a metodologia descrita por Wagner et al. (2008). A altura total do pão após o assamento foi medida utilizando uma régua graduada (1mm). 


\subsubsection{Perda de água durante o assamento}

Determinado de acordo com a metodologia descrita por Vanin et al. (2010). Foi realizado a pesagem dos pães antes e após o assamento. A diferença entre estas massas representa a quantidade de água perdida neste processo.

\subsubsection{Volume específico}

Determinado de acordo com a metodologia descrita por Kim et al. (2013). A análise foi realizada com o equipamento VolScan (Stable Micro Systems, Godalming, Reino Unido) com $4 \mathrm{~mm}$ de distância de laser. Para obter o volume específico foi calculado a razão entre volume obtido pelo equipamento (em mililitros) e o peso do pão (em gramas).

\subsubsection{Análise de dureza}

Determinado de acordo com a metodologia descrita por Bárcenas; Rosell, (2005). Foram cortadas fatias centrais do pão com $2,5 \mathrm{~cm}$ de espessura. A análise de dureza do miolo do pão foi realizada utilizando um texturômetro (TA-XT2i) com sonda cilíndrica de $20 \mathrm{~mm}$, compressão de $40 \%$ e com velocidades de pré-teste, teste e pós-teste de $2 \mathrm{~mm} / \mathrm{segundo}, 1,7$ $\mathrm{mm} /$ segundo e $10 \mathrm{~mm} /$ segundo, respectivamente.

\subsubsection{Análise do miolo do pão utilizando microscopia eletrônica de varredura (MEV)}

Para avaliar a morfologia do pão seguiu-se a metodologia descrito por Jafari et al. (2017). Os pães foram congelados e então secos em liofilizador (Terroni, LC 1500). Pequenos pedaços destas amostras foram cortados, a mão, e fixados em um cilindro de alumínio com uma fita dupla face de carbono e, em seguida, introduzidos no microscópio eletrônico de varredura (Hitachi Ltd, TM-3000, Japão). A análise foi realizada com voltagem de aceleração de $15 \mathrm{kV}$ a temperatura ambiente. Micrografia foram obtidas com ampliação de 50x e 1.500x. 


\subsubsection{Gelatinização dos grãos de amido}

A análise foi realizada na massa obtida logo após finalizar a etapa de mistura dos ingredientes. A taxa de aquecimento previamente calculada tanto para o miolo quanto para a crosta dos pães em cada uma das condições de assamento foi utilizada como parâmetro de velocidade de elevação da temperatura. Baseado nestas taxas foi considerado que os resultados simulam o que ocorre na crosta e no miolo do pão durante o assamento no forno.

O ensaio foi realizado em um calorímetro diferencial de varredura (DSC) (DSC 2010, TA instruments, USA) com um forno acoplado com função de realizar a simulação do processo de assamento (BÁRCENAS; ROSELL, 2005). Utilizou-se o metal índio como padrão. Primeiramente, foi realizado a calibração da linha de base e da temperatura para então iniciar a análise com as amostras (ZANONI; PERI; BRUNO, 1995).

Amostras da massa do pão (entre 10,48 a 16,62mg) foram adicionadas em um porta amostra de aço inoxidável, seladas e então introduzidas no equipamento, onde permaneceram durante 2 minutos a $20^{\circ} \mathrm{C}$ e em seguida foram congeladas até $-50^{\circ} \mathrm{C}$, para então serem aquecidas até $120^{\circ} \mathrm{C}$ (IZADI NAJAFABADI et al., 2014) utilizando as velocidades de aquecimento referentes a cada condição de assamento avaliada.

O Software de Análise Universal (V4.2E, TA Instruments, USA) foi utilizado para determinar as temperaturas inicial (Ti), onset (To), pico (Tp), conclusão (Tc) e a entalpia (J/g) representada pela área formada entre a linha de base e a curva (IZADI NAJAFABADI et al., 2014).

\subsubsection{Análise da estabilidade dos nutrientes}

\subsubsection{Preparo das amostras}

As amostras de pães foram congeladas, liofilizadas, trituradas e peneiradas (mesh 28). O processo de preparo das amostras foi o mesmo para todas as análises de estabilidade dos nutrientes. 


\subsubsection{2. Ácido fólico}

A avaliação do ácido fólico foi baseada na metodologia descrita por Boen et al. (2007) com algumas modificações. A Figura 2 apresenta o fluxograma com as etapas de extração e a Figura 3 o fluxograma com os procedimentos para a quantificação do teor de ácido fólico.

Primeiramente foi preparado a solução tampão fosfato, para isso, diluíram-se 1,6 gramas de fosfato de sódio em 1 litro de água ultrapura, em seguida o $\mathrm{pH}$ foi ajustado para 7,2 com solução de $\mathrm{NaOH} 1$ molar. Para cada amostra de pão (1 grama) foram adicionados $4 \mathrm{~mL}$ de tampão fosfato de sódio. Agitou-se a solução durante 10 minutos em agitador magnético (Gehaka, Color Squid). Em seguida a amostra permaneceu por 5 minutos no ultrassom (Unique, USC-1400) e então foi centrifugada (Eppendorf, 5430R) por 5 minutos $\left(10^{\circ} \mathrm{C}\right.$; 3000rcf). O sobrenadante foi reservado e uma nova extração foi realizada utilizando $5 \mathrm{ml}$ de tampão seguindo os mesmos procedimentos de agitação, ultrassom e centrifugação. O sobrenadante resultante foi adicionado ao sobrenadante da primeira extração. $\mathrm{O}$ extrato foi filtrado utilizando filtro de seringa de Nylon (13 $\mathrm{mm}$, com poros de $0,45 \mu \mathrm{m})$ e injetado na coluna cromatográfica (Shimadzu Corporation,L20495202650). Foi utilizado como fase móvel uma solução formada por $95 \%$ de tampão fosfato $(\mathrm{pH} 6,8)$ e $5 \%$ de acetonitrila. $\mathrm{O}$ tempo de corrida foi de 10 minutos e utilizou-se um detector de arranjo de diodos a $282 \mathrm{~nm}$. Realizaram-se também a curva padrão com ácido fólico e análises com padrão de ácido fólico, nas mesmas condições, para comparar e obter o tempo de retenção. 
Figura 2 - Fluxograma referente as etapas de extração do ácido fólico nas amostras.

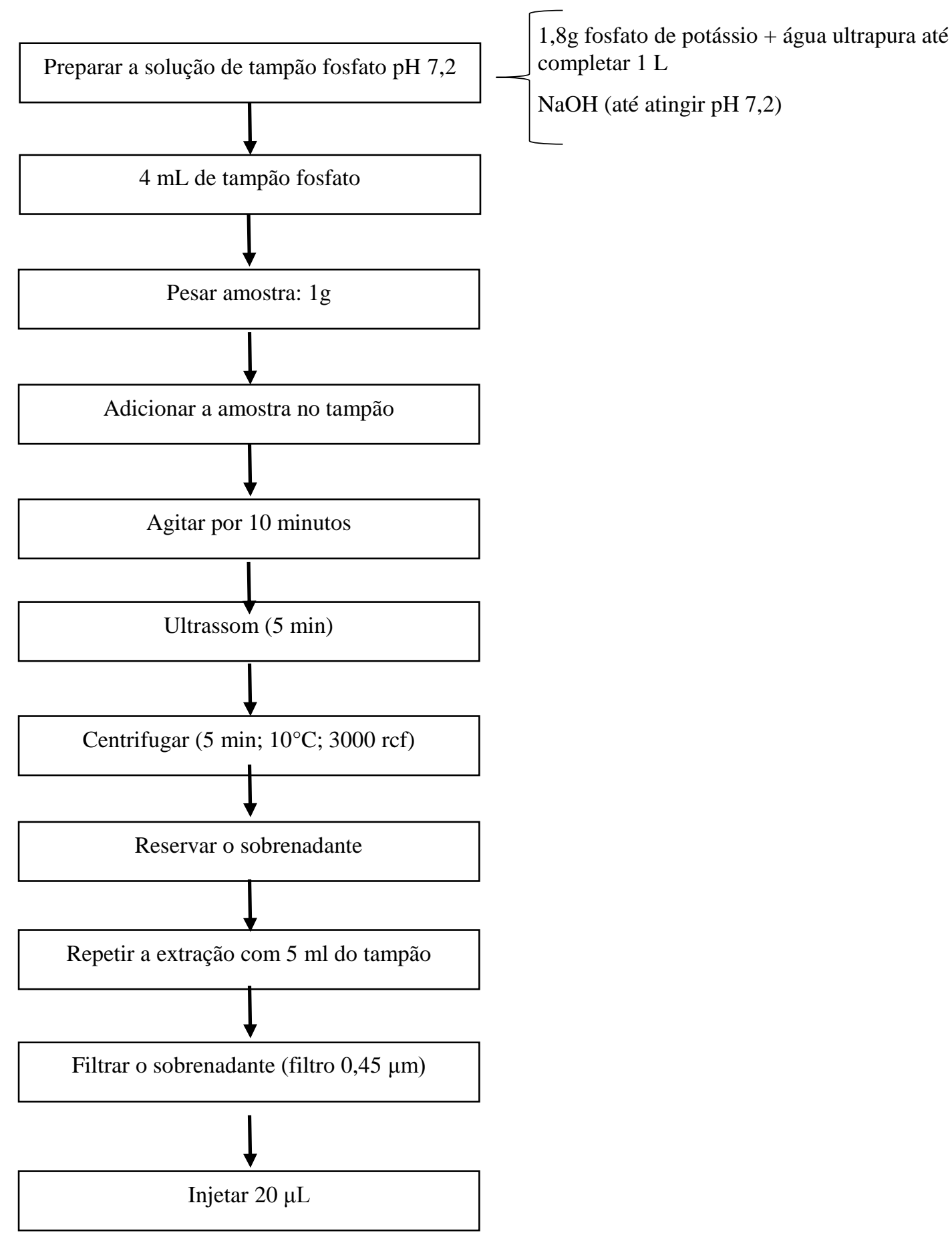

Fonte: Próprio autor, 2019. 
Figura 3 - Fluxograma referente aos procedimentos realizados para quantificar o ácido fólico presente na amostra.

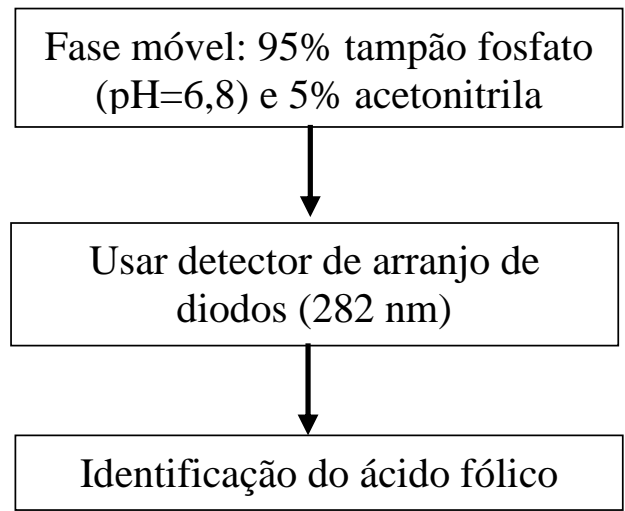

Análise com o padrão externo (ácido fólico padrão) para definir o tempo de retenção

Curva com ácido fólico padrão.

Fonte: Próprio autor, 2019.

\subsubsection{Minerais}

A determinação do conteúdo de minerais seguiu a metodologia descrita por Nogueira; Souza (2005) e foi realizada no Laboratório de Solos do Departamento de Ciências Agrárias da Faculdade de Zootecnia e Engenharia de Alimentos (FZEA/USP).

A determinação de enxofre, fósforo e boro foi realizada por meio de um espectrometro colorimétrico (Femto, 600 Soft, Brasil). Para o teor de potássio utilizou-se um fotômetro de chama (Micronal, B462, Brasil). Cálcio, magnésio, cobre, ferro, zinco e manganês foram determinados com um espectrometro de absorção atômica (Varian, Fast Sequential 2407S, Estados Unidos).

\subsubsection{Oxalato}

A determinação do conteúdo de oxalato seguiu as metodologias descritas por Kumar et al. (2017) e Baccan et al. (2001).

Pesou-se 1,0 grama da amostra e adicionaram-se $75 \mathrm{ml}$ de ácido sulfúrico $3 \mathrm{~N}$. Homogeneizou-se a solução sob agitação magnética (Agitador magnético Gehaka, Color 
Squid) durante 1 hora. Em seguida a solução foi filtrada com filtro de papel e $25 \mathrm{ml}$ do extrato foi utilizado na titulação contra uma solução de permanganato de potássio $0,1 \mathrm{~N}$. A titulação foi realizada sob aquecimento entre 80 a $90^{\circ} \mathrm{C}$ até visualizar uma cor rosa claro que permaneceu durante pelo menos 15 segundos (KUMAR; SHARMA; SINGH, 2017). A Figura 4 apresenta o fluxograma com os procedimentos realizados durante a análise de oxalato nas amostras.

Figura 4 - Fluxograma com a descrição dos procedimentos para determinação de oxalato nas amostras.

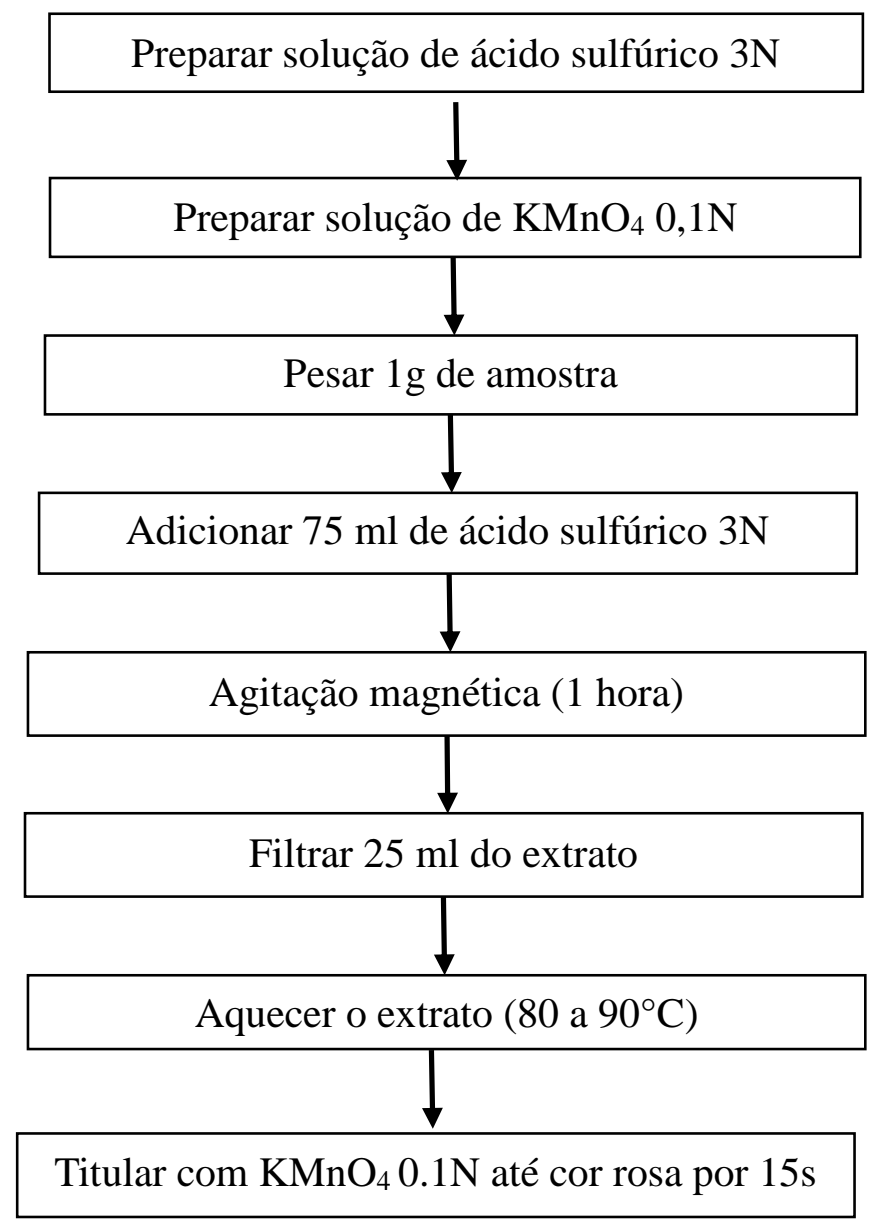

Fonte: Próprio autor, 2019.

Foi realizado também a padronização da solução de permanganato de potássio. Para isso, pesaram-se 0,1g de oxalato de potássio previamente seco em estufa (Marconi, MA 033) por 2 horas a $105^{\circ} \mathrm{C}$ e adicionaram-se $60 \mathrm{ml}$ de água ultrapura e $15 \mathrm{ml}$ de ácido sulfúrico diluído na proporção 1 para 8 . A solução foi então aquecida a uma temperatura de aproximadamente $90^{\circ} \mathrm{C}$ e então, realizou-se a titulação com permanganato de potássio $0,1 \mathrm{~N}$ até a solução apresentar cor rosa claro por pelo menos 30 segundos (BACCAN et al., 2001). 
A Figura 5 apresenta o fluxograma com os procedimentos realizados durante a análise de padronização.

Figura 5 - Fluxograma com os procedimentos realizados para a padronização do oxalato.

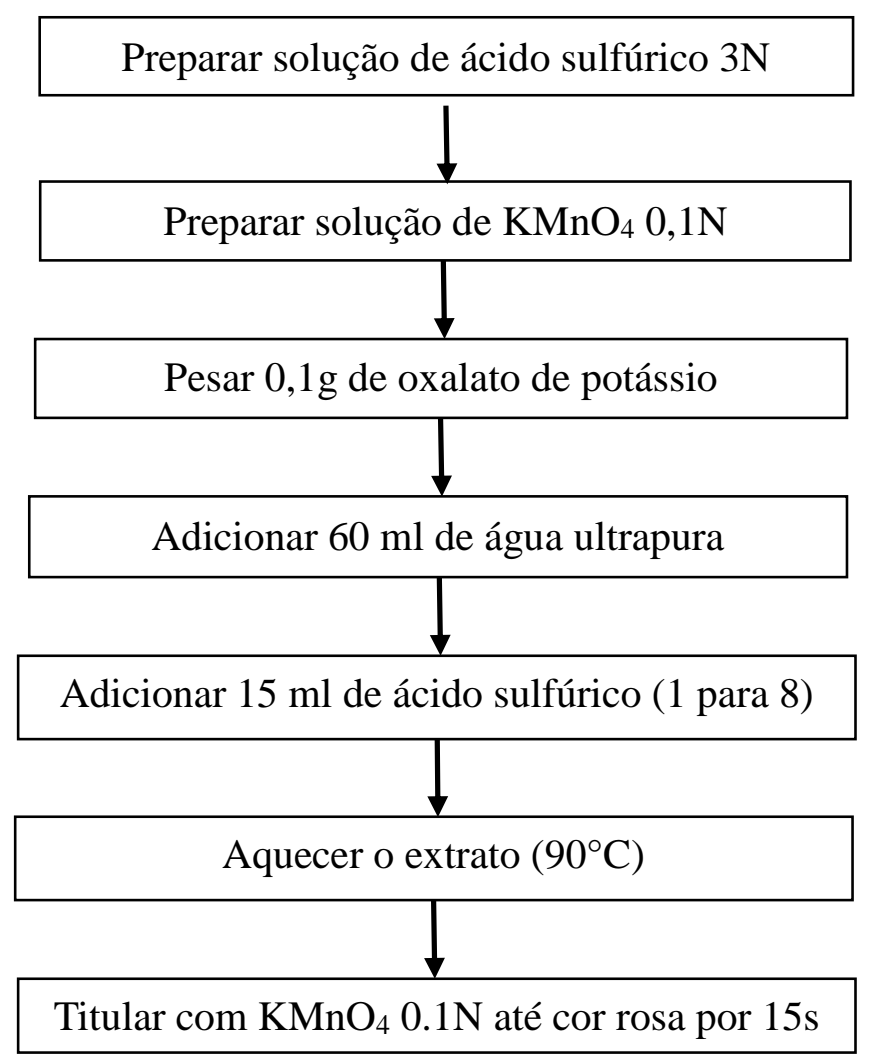

Fonte: Próprio autor, 2019.

O teor de oxalato da amostra foi definido de acordo com a quantidade de permanganato de potássio utilizada para titular 0,1 gramas de oxalato de potássio padrão. Os resultados foram expressos em mg por 100 gramas de extrato.

\subsubsection{Digestibilidade relativa da proteína}

A digestibilidade proteica foi avaliada de acordo com a metodologia descrita por Sęczyk et al (2016). A Figura 6 apresenta o fluxograma com os procedimentos realizados para obter o controle (tempo zero), a Figura 7 apresenta o fluxograma referente a digestibilidade nas amostras e a Figura 8 os procedimentos para avaliação do conteúdo de grupos de amino livre realizados tanto na amostra controle (tempo zero) quanto nas amostras digeridas. 
Figura 6 - Procedimentos realizados para obtenção do controle (tempo zero).

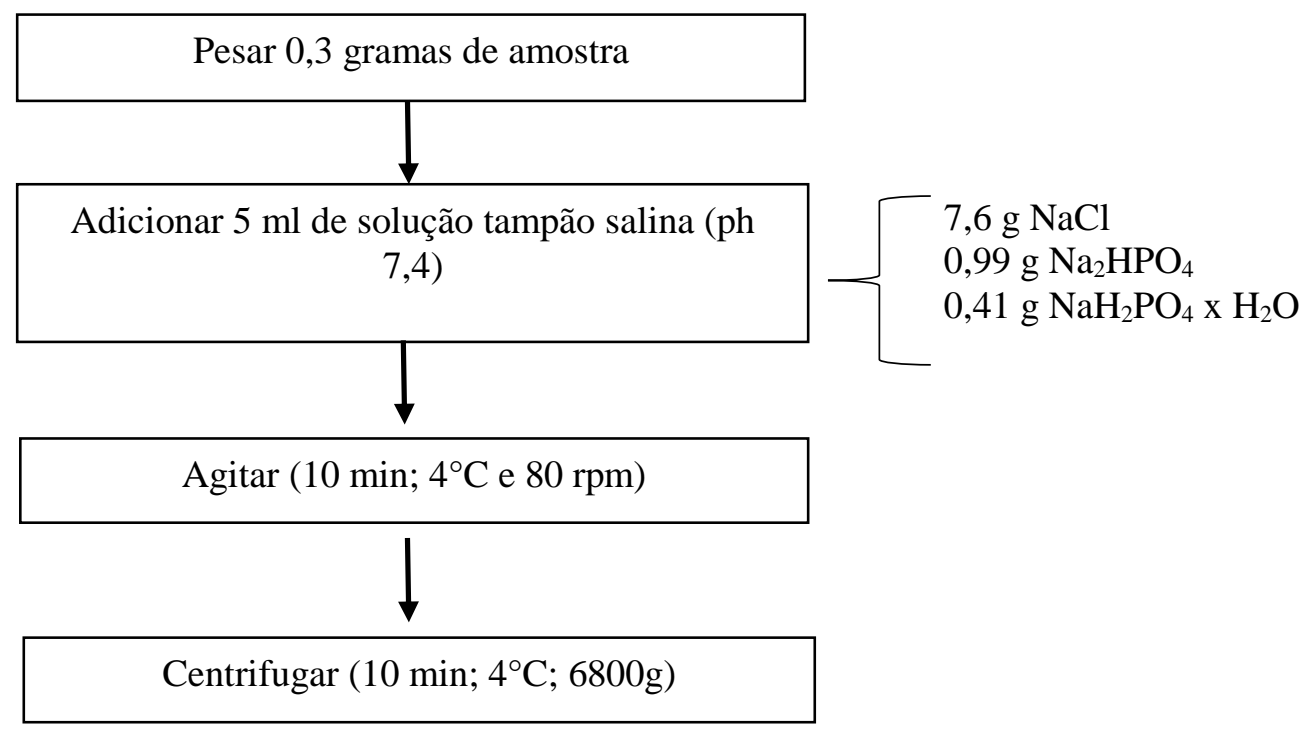

Fonte: Próprio autor, 2019.

Figura 7 - Fluxograma com os procedimentos realizados na etapa de digestibilidade das amostras.

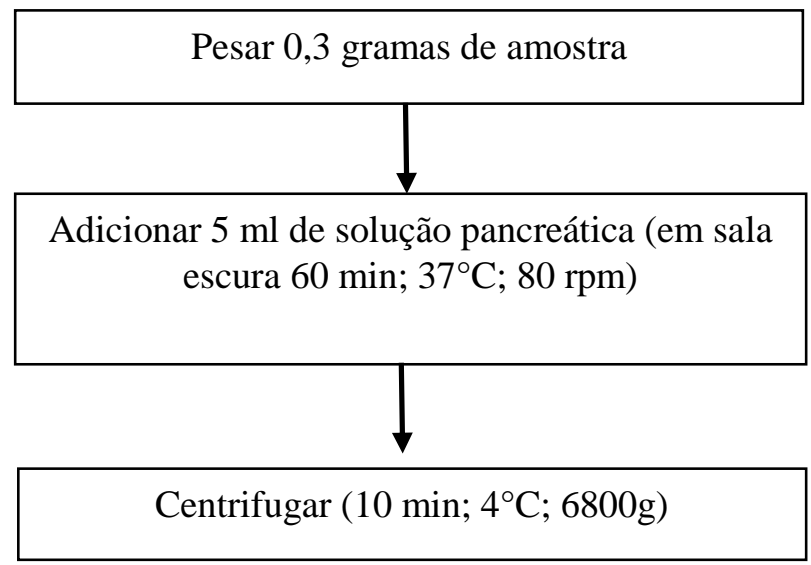

$75 \mathrm{mg}$ de pancreatina: (8xUSP unidade de atividade enzimática) em $100 \mathrm{~mL}$ de tampão fosfato salina

Fonte: Próprio autor, 2019. 
Figura 8 - Avaliação do conteúdo de grupos de amino livre antes e depois da digestão das amostras.

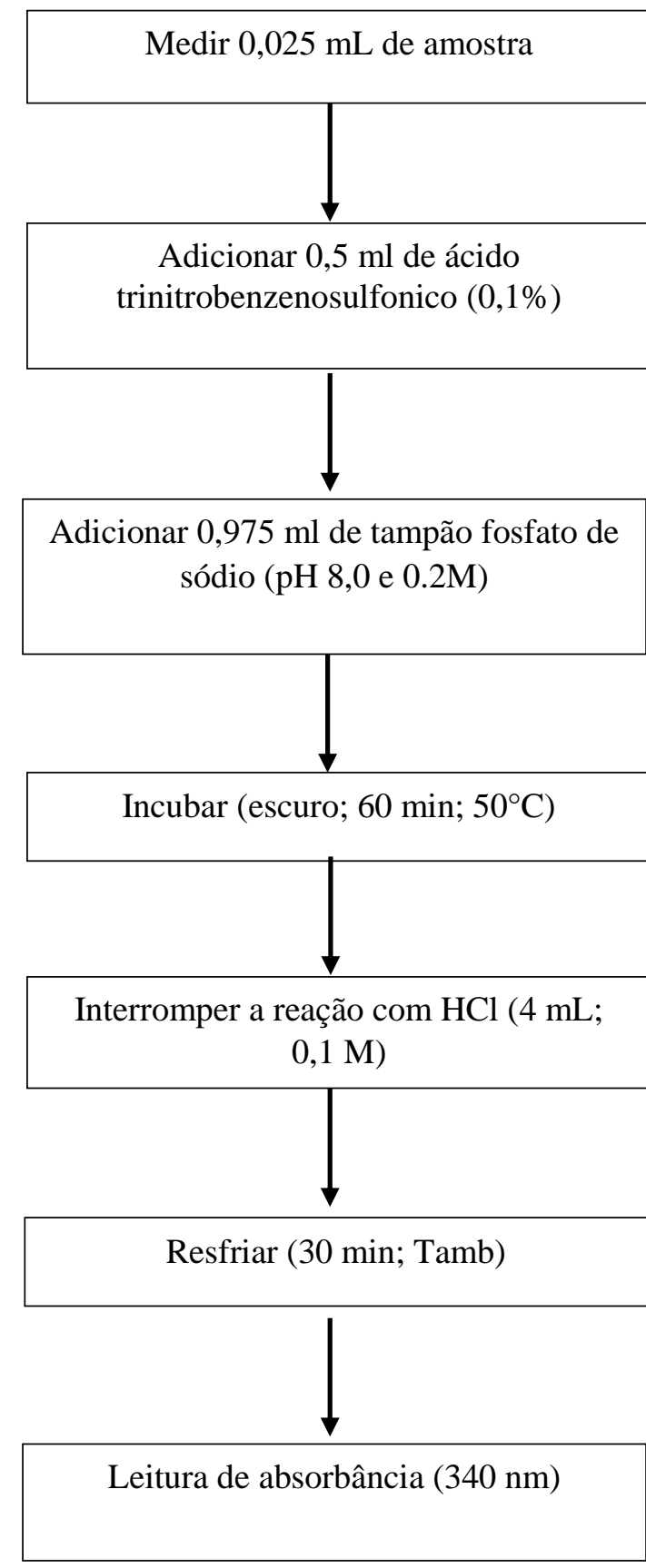

$1 \mathrm{ml}$ de ácido trinitrobenzenosulfonico 5\% diluído em $50 \mathrm{ml}$ de água

Adicionar a solução de $\mathrm{NaH}_{2} \mathrm{PO}_{4}$ na solução de $\mathrm{Na}_{2} \mathrm{HPO}_{4}$ até atingir o $\mathrm{pH} 8,0(43: 1000)$

\section{3,646g de $\mathrm{HCl}$ em 1 litro}

Corrigir os aminos livre utilizando o sobrenadante (tempo 0)

Expressar os resultados em $\alpha \mathrm{L}-$ leucina equivalente (LE) em $\mu \mathrm{g} / \mathrm{g}$.

Calcular a digestibilidade relativa da proteína como a razão entre o controle e os pães avaliados.

Fonte: Próprio autor, 2019.

Para obter o tempo zero (amostra não digerida) pesaram-se 0,3 gramas de pão e foram adicionadas $5 \mathrm{ml}$ de solução tampão fosfato salina $(0,1 \mathrm{~L}, \mathrm{pH} 7,4)$. A mistura foi agitada 
(agitador magnético, Gehaka, Color Squid) durante 10 minutos a $4^{\circ} \mathrm{C}$ e $80 \mathrm{rpm}$ e então centrifugada (Eppendorf, 5430R) por 10 minutos a $6800 \mathrm{~g}$ em $4^{\circ} \mathrm{C}$ para obter o sobrenadante (tempo zero).

Além disso, mais 0,3 gramas de amostras de pão foram pesadas e em uma sala escura, misturaram-se a esta amostra $5 \mathrm{ml}$ de solução pancreática $(75 \mathrm{mg}$ de pancreatina (8xUSP unidade de atividade enzimática) diluída em 100 mL de tampão fosfato salina), a solução foi transferida para uma incubadora (Marconi, MA-420) onde permaneceu sob agitação (80 rpm) e com temperatura controlada $\left(37^{\circ} \mathrm{C}\right)$ por 60 minutos. Realizou-se a centrifugação (Eppendorf, 5430R, $10 \mathrm{~min}, 6800 \mathrm{~g} \mathrm{e} 4^{\circ} \mathrm{C}$ ) para obter o sobrenadante.

A avaliação do conteúdo de grupos de amino livre foi realizada, tanto para a amostra digerida quanto para o tempo zero, seguindo a metodologia descrita por Adler-Nissen (1979). Mediram-se $0,025 \mathrm{~mL}$ de amostra e adicionaram-se 0,5 de ácido trinitrobenzenosulfonico $(0,1 \%)$ e $0,975 \mathrm{ml}$ de tampão fosfato de sódio $\left(0,2125 \mathrm{M} \mathrm{NaH}_{2} \mathrm{PO}_{4}+0,2125 \mathrm{M} \mathrm{Na}_{2} \mathrm{HPO}_{4} ; \mathrm{pH}\right.$ 8,0 e 0.2M). A solução foi incubada (Estufa, Marconi, MA-035), em ambiente escuro a temperatura de $50{ }^{\circ} \mathrm{C}$, durante 60 minutos. Utilizaram-se $4 \mathrm{~mL}$ de ácido clorídrico $0,1 \mathrm{M}$ para interromper a reação. Foi realizado o resfriamento por 30 minutos em temperatura ambiente e a leitura da absorbância (espectro, Perkin Elmer, Lambda 35) foi então realizada a $340 \mathrm{~nm}$. Para corrigir os aminos livre utilizou-se o sobrenadante (tempo 0) da primeira centrifugação. Os resultados foram expressos em termo de $\alpha \mathrm{L}$-leucina equivalente (LE) em $\mu \mathrm{g} / \mathrm{g}$ em base seca. A digestibilidade relativa da proteína foi obtido pela razão entre os pães avaliados e o controle (pão fermentado não assado).

\subsubsection{Análise estatística}

Todas as análises foram realizadas em triplicata e a estatística dos dados foi realizada no software SAS (versão 9.2, SAS, Inc.) utilizando o teste de Duncan com 95\% de confiança para determinar a diferença entre as médias. 


\section{RESULTADOS E DISCUSSÃO}

\subsection{Composição Centesimal da farinha de trigo}

A Tabela 3 apresenta a composição centesimal da farinha de trigo utilizada na produção dos pães neste trabalho. A farinha utilizada apresentou conteúdo de umidade médio de $11,80 \pm 0,55 \mathrm{~g}$ de água/ $100 \mathrm{~g}$ de farinha. Os valores na literatura estão coerentes com o obtido neste trabalho e demonstram que diferentes tipos de farinha de diferentes lotes e marcas distintas podem apresentam uma variação no conteúdo de umidade. Liu et al. (2018) avaliaram a composição centesimal da farinha de trigo e encontraram umidade igual a $8,34 \pm 0,12 \mathrm{~g}$ de água/ $100 \mathrm{~g}$ de farinha. Scheuer et al. (2014) realizaram uma pesquisa com farinhas de trigo refinada e integral para fabricação de pão e obtiveram valores médios de

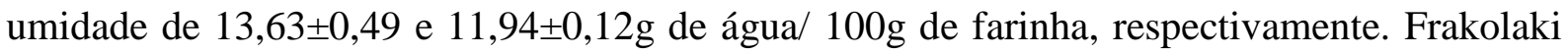
et al. (2018) trabalharam com farinha de trigo com 13,75 $\pm 0,27 \mathrm{~g}$ de água/ $100 \mathrm{~g}$ de farinha.

Tabela 3 - Composição centesimal da farinha de trigo utilizada na produção dos pães.

\begin{tabular}{ll}
\hline \multicolumn{1}{c}{ Composição centesimal } & g/ 100g de farinha \\
\hline Umidade & $11,80 \pm 0,55$ \\
Cinzas & $0,61 \pm 0,02$ \\
Extrato etéreo & $1,36 \pm 0,08$ \\
Proteínas & $11,12 \pm 0,21$ \\
Fração glicídica & 75,11 \\
\hline
\end{tabular}

Fonte: Próprio autor, 2018.

Quanto aos valores de cinzas, 0,61 $\pm 0,02 \mathrm{~g} / 100 \mathrm{~g}$ de farinha, estão de acordo com os resultados apresentados nos trabalhos realizados por Frakolaki et al. (2018), 0,63 $\pm 0,09 \mathrm{~g} / 100 \mathrm{~g}$ de farinha, Debonne et al. (2017), 0,68 g/100g de farinha e Chen et al. (2019) com 0,5 g/100g de farinha.

Para o conteúdo de extrato etéreo foram encontrados neste trabalho 1,36 $\pm 0,08 \mathrm{~g} / 100 \mathrm{~g}$

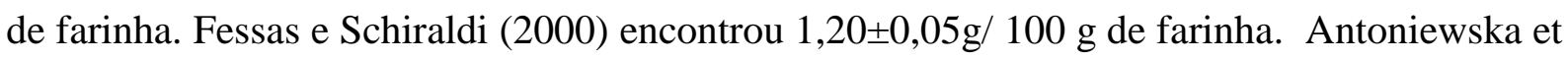
al. (2018) trabalharam com farinha de trigo refinada com 1,5 g/100g de farinha. Bressiani et al. (2017) também avaliaram farinha de trigo e encontraram $1.59 \pm 0.08 \mathrm{~g} / 100 \mathrm{~g}$ de farinha. 
Em relação aos valores de proteína a farinha contém 11,12 $\pm 0,21 \mathrm{~g} / 100 \mathrm{~g}$ de farinha. Foram encontrados na literatura valores de 7,39 g/100 g de farinha (GUADARRAMALEZAMA et al., 2016), 10,21 g/100 g de farinha (WAGNER et al., 2008), 11,20 g/100 g de farinha (FRAKOLAKI et al., 2018), 11,20 $\pm 0,02 \mathrm{~g} / 100 \mathrm{~g}$ de farinha (ANTONIEWSKA et al., 2018). Estes valores estão próximos ao encontrado neste trabalho.

Quanto a fração glicídica do pão, o valor obtido neste trabalho $(75,11 \mathrm{~g} / 100 \mathrm{~g}$ de farinha) está próximo ao encontrado na literatura, por Kim et al. (2013): 77,2 g/100g de

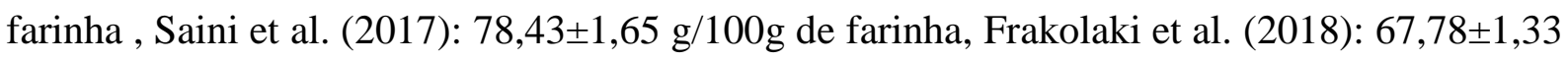
$\mathrm{g} / 100 \mathrm{~g}$ de farinha e Mildner-Szkudlarz et al. (2017): 79,2 g/100g de farinha .

\subsection{Aquisição da temperatura local ao longo do assamento}

O efeito da introdução ou não de vapor sobre a elevação da temperatura local ao longo do assamento foi avaliado no miolo (Figura 9) e na crosta (Figura 10) dos pães. Com estes valores obtiveram-se as taxas de aquecimento que variaram entre 8,49 a $30,89{ }^{\circ} \mathrm{C} / \mathrm{min}$. $\mathrm{Na}$ Tabela 4 é possível verificar a influência da temperatura e da introdução de vapor sobre a taxa de aquecimento.

A elevação da temperatura de assamento proporciona atingir mais rapidamente a temperatura final no miolo (Figuras 9), além disso, ela também fornece maiores temperaturas na região da crosta (Figura 10) e maiores taxas de aquecimento (Tabela 4). Porém, foi verificado uma diferença quanto a região (crosta ou miolo) analisada. Tanto o tratamento com introdução de vapor quanto o sem vapor apresentaram uma taxa de aquecimento maior na crosta do que no miolo. No miolo há maior quantidade de água do que na crosta e segundo WAGNER et al. (2007) esta quantidade impede que a região atinja a temperatura de ebulição $\left(100^{\circ} \mathrm{C}\right)$, por isso está correto obter maiores taxas de aquecimento para a crosta. 
Figura 9 - Temperaturas obtidas ao longo assamento medidas no miolo dos pães assados em diferentes temperaturas $\left(160^{\circ} \mathrm{C}, 190^{\circ} \mathrm{C}\right.$ e $\left.220^{\circ} \mathrm{C}\right)$ com $(\mathrm{CV})$ e sem (SV) adição de vapor.

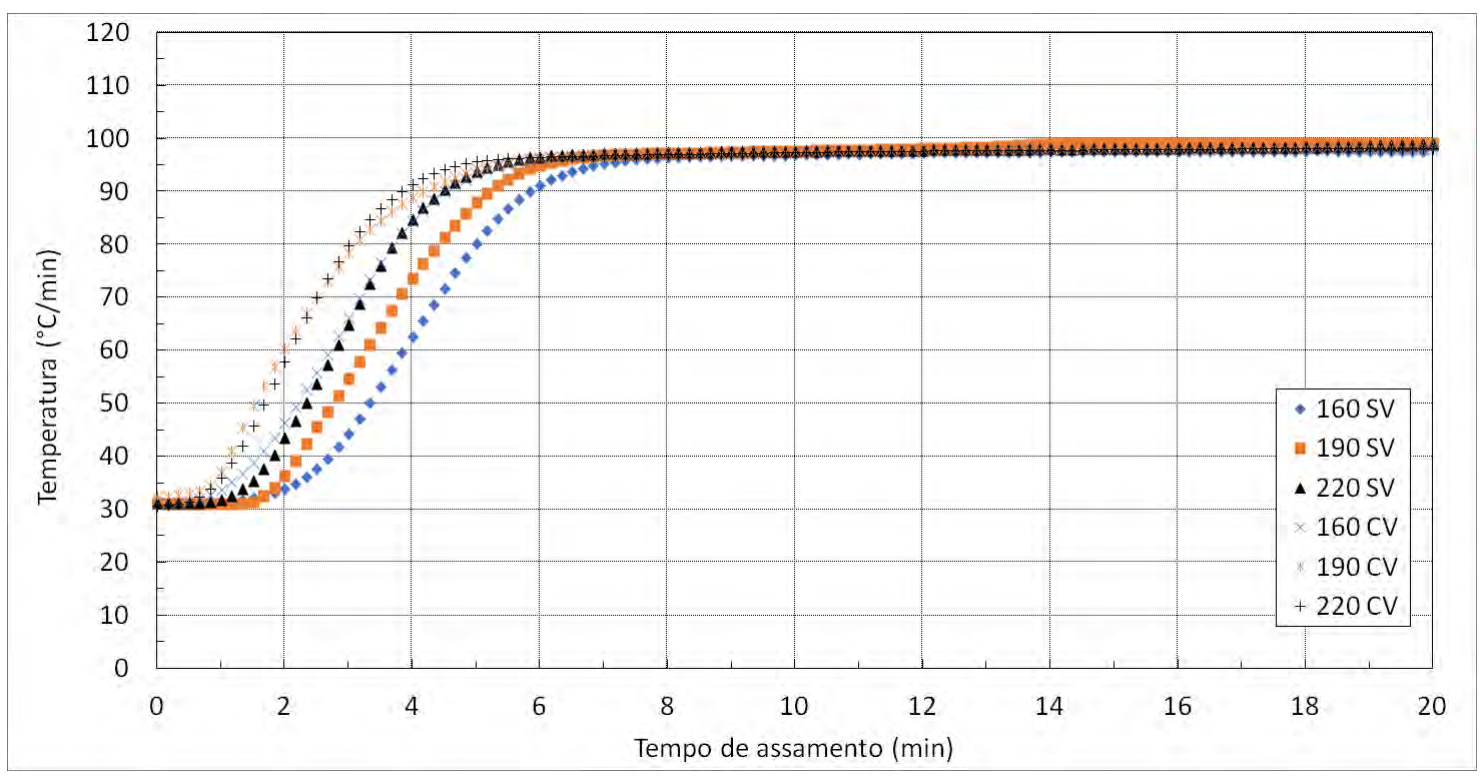

Fonte: Próprio autor, 2019.

Figura 10 - Temperaturas obtidas ao longo do assamento na crosta dos pães assados em diferentes temperaturas $\left(160^{\circ} \mathrm{C}, 190^{\circ} \mathrm{C}\right.$ e $\left.220^{\circ} \mathrm{C}\right) \mathrm{com}(\mathrm{CV})$ e sem $(\mathrm{SV})$ adição de vapor.

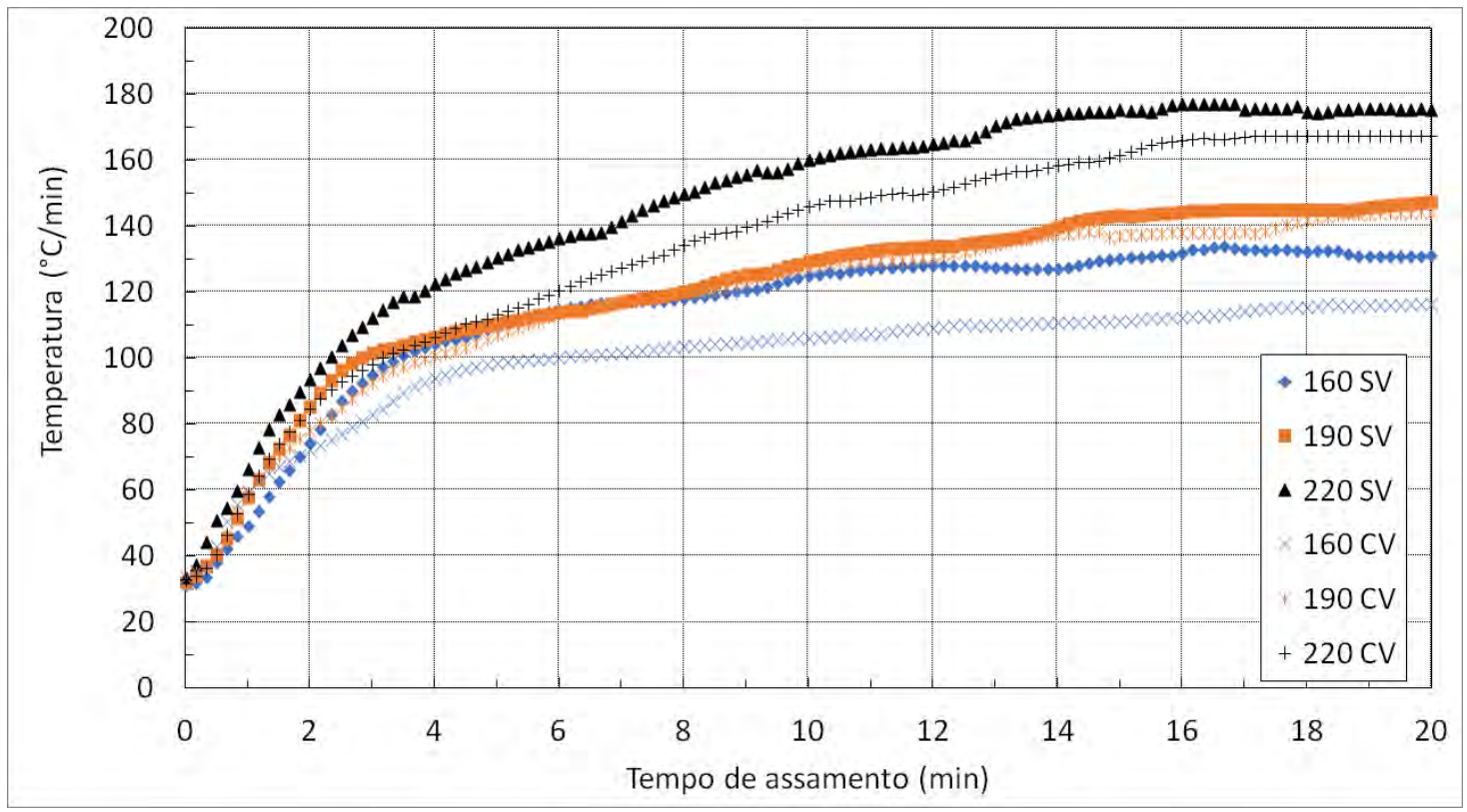

Fonte: Próprio autor, 2019. 
Em relação a introdução ou não de vapor, ocorreu uma diferença entre os tratamentos assados com e sem introdução de vapor. Está diferença é mais visível na região do miolo, uma vez que, na crosta os resultados apresentaram desvio padrão maiores em comparação aos obtidos no miolo. Isso ocorreu devido ao crescimento do pão que pode ter deslocado o termopar fixado na crosta do pão. Para os pães assados com introdução de vapor a taxa de aquecimento foi maior na região do miolo. Já, para o tratamento sem introdução de vapor, a taxa de aquecimento foi mais rápida na crosta. Está diferença na taxa de aquecimento é uma consequência da diferença na elevação da temperatura entre os tratamentos com e sem vapor e está diretamente relacionada com a umidade presente em cada região. Em um tratamento sem introdução de vapor, a energia gerada pelo aquecimento é utilizada para aquecer a massa do pão, porém, quando ocorre introdução de vapor, tem-se a formação de uma superfície úmida, devido ao vapor que condensado nesta região. Neste caso, a energia é utilizada para evaporar a água e aquecer a amostra (LE-BAIL et al., 2011) e por isso, o aquecimento na crosta é menor para o tratamento com vapor.

Tabela 4 - Taxa de aquecimento na crosta e no miolo dos pães assados em diferentes temperaturas $\left(160^{\circ} \mathrm{C}, 190^{\circ} \mathrm{C}\right.$ e $\left.220^{\circ} \mathrm{C}\right)$ com e sem adição de vapor.

\begin{tabular}{|c|c|c|}
\hline \multirow{2}{*}{ Temperatura $\left({ }^{\circ} \mathbf{C}\right)$} & \multicolumn{2}{|c|}{ Taxa de aquecimento $\left({ }^{\circ} \mathrm{C} / \mathrm{min}\right)$} \\
\hline & Crosta & Miolo \\
\hline \multicolumn{3}{|l|}{ Sem vapor } \\
\hline $160^{\circ} \mathrm{C}$ & $19,42 \pm 6,30^{\mathrm{bA}}$ & $8,49 \pm 0,17^{\mathrm{cB}}$ \\
\hline $190^{\circ} \mathrm{C}$ & $23,75 \pm 2,52^{\mathrm{abA}}$ & $9,70 \pm 0,39 \mathrm{a}^{\mathrm{bB}}$ \\
\hline $220^{\circ} \mathrm{C}$ & $30,89 \pm 7,12^{\mathrm{aA}}$ & $11,31 \pm 0,24^{\mathrm{aB}}$ \\
\hline \multicolumn{3}{|l|}{ Com vapor } \\
\hline $160^{\circ} \mathrm{C}$ & $13,80 \pm 4,58^{\mathrm{bA}}$ & $10,44 \pm 0,21^{\mathrm{cA}}$ \\
\hline $190^{\circ} \mathrm{C}$ & $16,82 \pm 0,81^{\mathrm{abB}}$ & $11,42 \pm 0,89^{\mathrm{bA}}$ \\
\hline $220^{\circ} \mathrm{C}$ & $20,22 \pm 1,48^{\mathrm{aA}}$ & $12,79 \pm 0,42^{\mathrm{aA}}$ \\
\hline
\end{tabular}

*Letras minúsculas diferentes na mesma coluna, para a mesma condição de vapor, indicam diferença estatística entre as temperaturas de assamento;

**Letras maiúsculas diferentes na mesma coluna para a mesma condição de temperatura, indicam diferença estatística entre os tratamentos com e sem vapor.

Fonte: Próprio autor, 2019. 


\subsection{Avaliação das propriedades físicas dos pães}

\subsubsection{Aspectos visuais da crosta do pão}

A Figura 11 apresenta as imagens das crostas dos pães assados nas temperaturas de $160^{\circ} \mathrm{C}, 190^{\circ} \mathrm{C}$ e $220^{\circ} \mathrm{C}$ durante $9,12,15$ e 20 minutos, sem e com introdução de vapor. Algumas mudanças nos aspectos visuais podem ser observadas, como por exemplo a variação na cor. Os pães que permaneceram por mais tempo no forno com uma temperatura mais elevada apresentaram maior escurecimento em comparação com aqueles que permaneceram por menores tempos em temperaturas mais brandas. A formação da cor está relacionada com a reação de Maillard, que, por sua vez depende do teor de lipídios, umidade, e das condições de assamento como a temperatura, por exemplo (TAVARES et al., 2018). A temperatura exerce, portanto, grande influência na formação da cor do pão, sendo que as temperaturas mais elevadas favorecem a formação de pigmentos (SHITTU; RAJI; SANNI, 2007).

O brilho também foi é um aspecto que sofreu mudanças, neste caso o vapor exerceu maior influência do que o tempo e a temperatura de assamento. Pães assados com introdução de vapor apresentaram um brilho mais intenso. A introdução de vapor durante o assamento favorece a penetração do calor (PYLER, E. J; GORTON, 2008), permite que ocorra uma rápida expansão da massa do pão (AMENDOLA; REES, 2003; PYLER, E. J; GORTON, 2008), contribui com a precipitação dos elementos voláteis (AMENDOLA; REES, 2003) e também contribui com a formação do brilho (PYLER, E. J; GORTON, 2008).

Além dos aspectos relacionados a cor, é possível também visualizar que os pães assados a baixa temperatura por curto período de tempo apresentaram crosta lisa, este efeito é mais intensificado nos pães assados sem introdução de vapor e está diretamente relacionado com a crocância da crosta (ABNT; SEBRAE, 2015), um critério importante para determinar a aceitação do produto (ALTAMIRANO-FORTOUL et al., 2012). 
Figura 11 - Aspectos visuais da crosta de pães assados sob diferentes condições de tempo $(9,12,15$ e $20 \mathrm{~min})$, temperatura $\left(160^{\circ} \mathrm{C}, 190^{\circ} \mathrm{C}\right.$ e $\left.220^{\circ} \mathrm{C}\right)$ e umidade no forno (com e sem introdução de vapor).

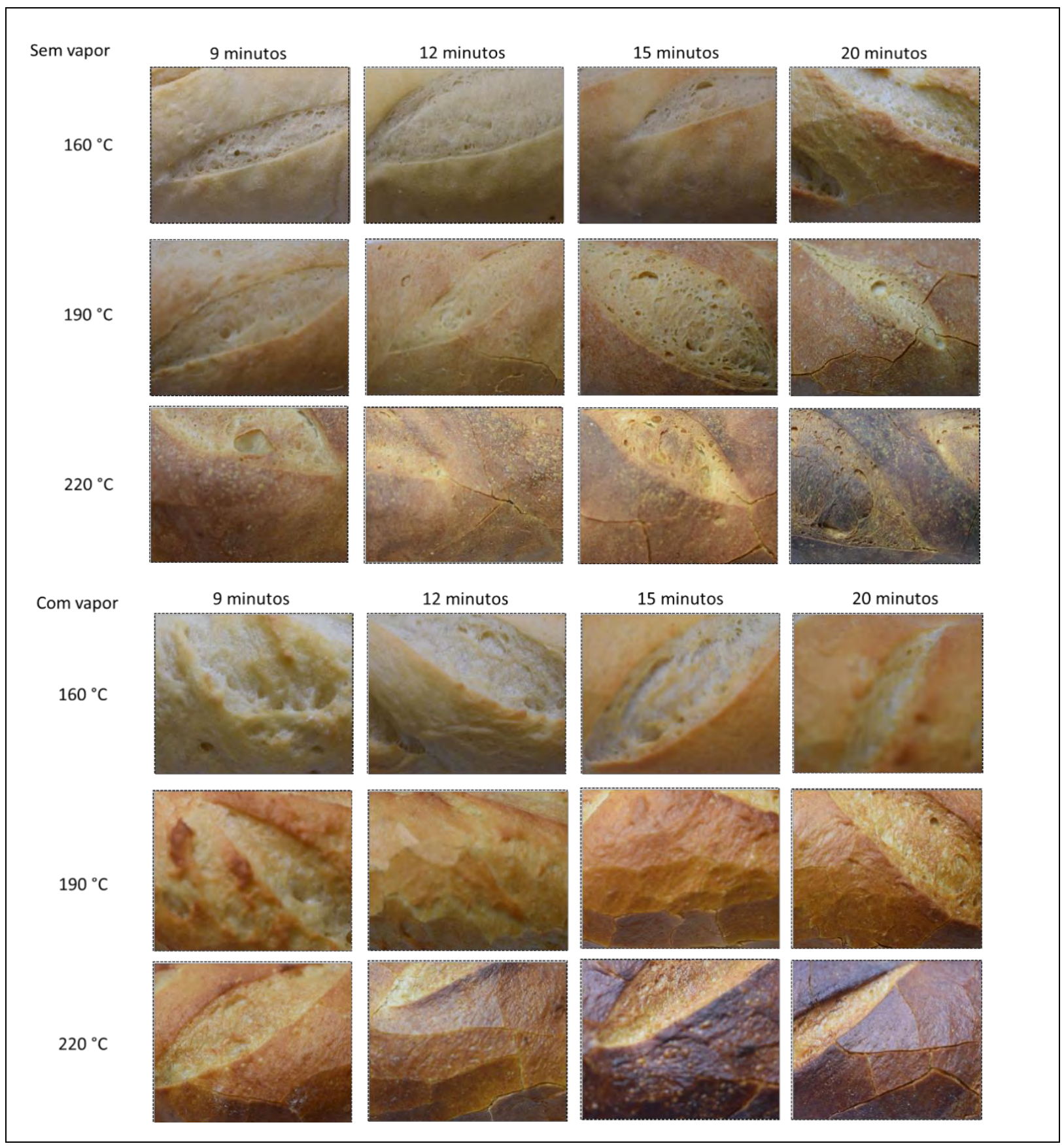

Fonte: Próprio autor, 2018. 


\subsubsection{Parâmetros de cor}

\section{Luminosidade $\mathbf{L}^{*}$}

A Tabela 5 apresenta os resultados de luminosidade $L^{*}$ do miolo dos pães assados com e sem introdução de vapor nas temperaturas de 160,190 e $220^{\circ} \mathrm{C}$, para os tempos de 9 , 12,15 e 20 minutos. Os valores variaram entre 74,17 a 79,23.

O aumento do tempo de assamento provocou variação significativa no parâmetro de cor luminosidade $\mathrm{L}^{*}$ dos miolos dos pães assados sem introdução de vapor. Conforme pode ser observado na Tabela 5, os assamentos mais longos apresentaram pães com menor luminosidade. Para os pães assados com vapor apenas a $160^{\circ} \mathrm{C}$ foi verificado uma tendência a reduzir o valor de $\mathrm{L}^{*}$ conforme aumentaram-se o tempo de assamento. A $190^{\circ} \mathrm{C}$ não foi verificado diferença estatística entre os quatro tempos avaliados. Já para $220^{\circ} \mathrm{C}$ não foi possível estabelecer uma tendência de aumento ou redução dos parâmetros de cor luminosidade $\mathrm{L}^{*}$ com o aumento do tempo.

A elevação da temperatura de assamento não provocou aumento significativo no parâmetro de cor L* dos miolos dos pães, com exceção para as condições com vapor nos tempos de 15 e 20 minutos, onde o aumento da temperatura de assamento provocou aumento significativo dos valores de $\mathrm{L}^{*}$ do miolo dos pães.

O uso de vapor ou não no assamento não provocou variação significativa no parâmetro de cor $\mathrm{L}^{*}$ dos miolos dos pães, com exceção dos pães assados a $220^{\circ} \mathrm{C}$ por 9 e 15 minutos.

Sui, Yao e Zhou (2015) verificaram que um aumento do tempo reduziu a luminosidade. Erbas et al. (2012) também verificaram um aumento no parâmetro de cor luminosidade $\mathrm{L}^{*}$ no miolo dos pães, para as temperaturas mais elevadas. A luminosidade do miolo do pão, segundo o estudo realizado por Erbas et al. (2012) é de 64,9 $\pm 2,9$. Fu et al., (2018) encontraram valor de luminosidade do miolo do pão igual a 65,85 \pm 0.36 . Estes dados demonstram que o valor encontrado neste estudo está acima do obtido em alguns trabalhos, o que poderia indicar um pão com um miolo mais escuro. Por outro lado, Özkaya, Baumgartner e Özkaya (2018) obtiveram luminosidade de 75,06, um valor coerente com os observados neste trabalho.Todos os pães foram produzidos com farinha de trigo, porém, apresentaram variação na luminosidade. Pode se verificar, portanto, que não existe um valor de luminosidade único que possa ser utilizado como critério de melhor qualidade. 
Tabela 5 - Resultados de luminosidade $\mathrm{L}^{*}$ do miolo dos pães assados com e sem introdução de vapor nas temperaturas de 160,190 e $220^{\circ} \mathrm{C}$, para os tempos de $9,12,15$ e 20 minutos.

Temperatura

Tempo (min)

\begin{tabular}{llllll}
\cline { 2 - 4 }$\left({ }^{\circ} \mathbf{C}\right)$ & 9 & 12 & 15 & 20
\end{tabular}

Sem vapor

\begin{tabular}{lllll}
160 & $77,37 \pm 0,33^{\mathrm{aA} 1}$ & $76,85 \pm 1,61^{\mathrm{aA} 1}$ & $76,47 \pm 2,02^{\mathrm{abA} 1}$ & $75,17 \pm 1,13^{\mathrm{bA} 1}$ \\
190 & $76,37 \pm 0,62^{\mathrm{aA} 1}$ & $76,98 \pm 1,21^{\mathrm{aA} 1}$ & $75,34 \pm 0,68^{\mathrm{bA} 1}$ & $75,38 \pm 0,74^{\mathrm{bA} 1}$ \\
220 & $76,82 \pm 1,70^{\mathrm{abA} 2}$ & $77,77 \pm 0,96^{\mathrm{aA} 1}$ & $76,58 \pm 1,76^{\mathrm{abA} 1}$ & $75,94 \pm 1,92^{\mathrm{bA} 1}$ \\
\hline
\end{tabular}

Com vapor

\begin{tabular}{lllll}
160 & $78,26 \pm 2,42^{\mathrm{aA} 1}$ & $76,48 \pm 2,14^{\mathrm{ba} 1}$ & $74,94 \pm 2,17^{\mathrm{cbB} 1}$ & $74,17 \pm 1,96^{\mathrm{cB} 1}$ \\
$\mathbf{1 9 0}$ & $77,31 \pm 2,32^{\mathrm{aA} 1}$ & $77,09 \pm 3,07^{\mathrm{aA} 1}$ & $76,26 \pm 2,45^{\mathrm{aAB} 1}$ & $75,46 \pm 2,81^{\mathrm{aAB} 1}$ \\
$\mathbf{2 2 0}$ & $79,23 \pm 1,44^{\mathrm{aA} 1}$ & $77,75 \pm 1,51^{\mathrm{bA} 1}$ & $78,28 \pm 1,63^{\mathrm{abA} 2}$ & $76,82 \pm 1,16^{\mathrm{bA} 1}$ \\
\hline
\end{tabular}

*Letras minúsculas diferentes na mesma linha indicam diferença estatística entre os tempos de assamento para a mesma condição de vapor e temperatura;

**Letras maiúsculas diferentes na mesma coluna indicam diferença estatística entre as diferentes temperaturas de assamento para uma mesma condição de vapor e tempo;

***Números diferentes na mesma coluna para a mesma condição de tempo e temperatura, indicam diferença estatística entre os tratamentos com e sem vapor.

Fonte: Próprio autor, 2018.

Em relação aos valores de luminosidades $L^{*}$ na crosta do pão, os valores variaram entre 42,24 a 82,99. Por meio da Tabela 6, é possível observar que, neste caso, o tempo de assamento teve efeito significativo na luminosidade em ambos os tratamentos, com e sem vapor. Quanto maior o tempo de assamento menor a luminosidade do pão. Sui, Yap e Zhou (2015) avaliaram as mudanças na cor da crosta do pão ao longo do assamento, de 0 a 12 minutos, e constataram uma elevação do valor de L* nos primeiros minutos seguido por uma redução em função do aumento do tempo de assamento.

Além disso, verificou-se que o aumento da temperatura de assamento (com e sem vapor) provocou diminuição significativo no parâmetro de cor $\mathrm{L}^{*}$ da crosta dos pães.

O uso de vapor no assamento provocou redução significativa no parâmetro de cor L* da crosta dos pães, efeito mais claramente observado para os tempos 15 e 20 minutos. Pode-se induzir que o vapor tem maior efeito sobre a luminosidade da crosta para os pães com maiores tempos de assamento.

Em comparação com os aspectos visuais, foi verificado que o aumento do tempo e temperatura de assamento provocaram escurecimento da crosta do pão. Logo, a redução nos valores de $\mathrm{L}^{*}$ é uma consequência do maior escurecimento que ocorreu nos pães que 
permanecem por longos períodos no forno ou que foram submetidos a assamentos com elevadas temperaturas.

Tabela 6 - Resultados de luminosidade $\mathrm{L}^{*}$ da crosta dos pães assados com e sem introdução de vapor nas temperaturas de 160,190 e $220^{\circ} \mathrm{C}$, para os tempos de $9,12,15$ e 20 minutos.

\begin{tabular}{lcccc}
\hline \multirow{2}{*}{ Temperatura $\left({ }^{\circ} \mathbf{C}\right)$} & \multicolumn{4}{c}{ Tempo (min) } \\
\cline { 2 - 5 } & 9 & 12 & 15 & 20 \\
\hline Sem vapor & & & & \\
$\mathbf{1 6 0}$ & $82,99 \pm 1,84^{\mathrm{aA} 1}$ & $80,50 \pm 1,96^{\mathrm{bA} 1}$ & $78,79 \pm 2,04^{\mathrm{bA} 1}$ & $74,89 \pm 1,48^{\mathrm{cA} 1}$ \\
$\mathbf{1 9 0}$ & $74,16 \pm 2,02^{\mathrm{aB} 1}$ & $68,86 \pm 1,28^{\mathrm{bB} 1}$ & $65,32 \pm 2,32^{\mathrm{cB} 1}$ & $63,11 \pm 3,57^{\mathrm{cB} 1}$ \\
$\mathbf{2 2 0}$ & $61,10 \pm 3,16^{\mathrm{aC} 2}$ & $58,85 \pm 3,24^{\mathrm{aC} 1}$ & $53,30 \pm 4,28^{\mathrm{bC} 1}$ & $53,10 \pm 2,90^{\mathrm{bC} 1}$ \\
\hline $\mathbf{C o m}$ vapor & & & & \\
\hline $\mathbf{1 6 0}$ & $82,40 \pm 1,67^{\mathrm{aA} 1}$ & $79,39 \pm 0,96^{\mathrm{bA} 1}$ & $74,34 \pm 2,32^{\mathrm{cA} 2}$ & $68,53 \pm 2,98^{\mathrm{dA} 2}$ \\
$\mathbf{1 9 0}$ & $73,56 \pm 1,49^{\mathrm{aB} 1}$ & $65,72 \pm 2,81^{\mathrm{bB} 2}$ & $61,38 \pm 2,30^{\mathrm{cB} 2}$ & $54,48 \pm 2,21^{\mathrm{dB} 2}$ \\
$\mathbf{2 2 0}$ & $65,81 \pm 2,03^{\mathrm{aC} 1}$ & $56,65 \pm 2,42^{\mathrm{bC} 1}$ & $52,06 \pm 0,52^{\mathrm{cC} 1}$ & $42,24 \pm 1,49^{\mathrm{dC} 2}$ \\
\hline
\end{tabular}

*Letras minúsculas diferentes na mesma linha indicam diferença estatística entre os tempos de assamento para a mesma condição de vapor e temperatura;

**Letras maiúsculas diferentes na mesma coluna indicam diferença estatística entre as diferentes temperaturas de assamento para uma mesma condição de vapor e tempo;

***Números diferentes na mesma coluna para a mesma condição de tempo e temperatura, indicam diferença estatística entre os tratamentos com e sem vapor.

Fonte: Próprio autor, 2018.

Não é possível definir um melhor valor de luminosidade do pão, uma vez que este critério é muito subjetivo, e pode variar muito dependendo do país onde o pão será consumido. Por exemplo, na Turquia, Erbas et al. (2012) produziram pães com valores de luminosidade de 64,9 $\pm 2,9$, na Índia, Pasrija et al. (2015) trabalharam com pães com luminosidade entre 65,7 a 51,2, já na Itália os valores de luminosidade obtidos por MARTI et al. (2018) foram de 71,22 a 64,61 Em relação à crosta, também existe uma grande faixa de valores de luminosidade encontrada. No Brasil, por exemplo, foram obtidos valores entre 81,4 a 50,6 (FEITOSA et al., 2013), já na Argentina este valor deve estar próximo a 70 para apresentar boa aceitação (PURLIS, 2011), enquanto na Turquia foram encontrados valores entre 64,52 a 47,8 (ERBAS et al., 2012). Todos os pães foram produzidos utilizando farinha de trigo, porém apresentaram valores distintos entre si. Assim, não é possível decidir qual o 
melhor tempo de assamento baseado nos critérios de luminosidade do pão, porém estes dados se fazem úteis para a caracterização do produto.

\section{Croma a*}

Como apresentado na Tabela 7 , os valores de croma a* para o miolo variaram entre 1,76 a 2,24. De maneira geral, o aumento do tempo de assamento não provocou efeito significativo no parâmetro de cor croma $a^{*}$ dos miolos dos pães submetidos a diferentes condições de assamento.

Já o aumento da temperatura de assamento provocou aumento significativo no parâmetro de cor croma $a^{*}$ dos miolos dos pães para algumas condições. No assamento sem vapor, por 12 minutos e no assamento com vapor por 12 minutos e 20 minutos a elevação da temperatura provocou aumento significativo do croma $\mathrm{a}^{*}$.

E por fim, o uso de vapor ou não no assamento não provocou variação significativa no parâmetro de cor croma $a^{*}$ dos miolos dos pães.

Tabela 7 - $\quad$ Resultados de croma a* do miolo dos pães assados com e sem introdução de vapor nas temperaturas de 160,190 e $220^{\circ} \mathrm{C}$, para os tempos de $9,12,15$ e 20 minutos.

\begin{tabular}{|c|c|c|c|c|}
\hline \multirow{2}{*}{ Temperatura $\left({ }^{\circ} \mathbf{C}\right)$} & \multicolumn{4}{|c|}{ Tempo (min) } \\
\hline & 9 & 12 & 15 & 20 \\
\hline \multicolumn{5}{|l|}{ Sem vapor } \\
\hline 160 & $2,04 \pm 0,12^{\mathrm{aA} 1}$ & $1,84 \pm 0,11^{\mathrm{bB} 1}$ & $1,95 \pm 0,12^{\mathrm{abA} 1}$ & $1,85 \pm 0,05^{\mathrm{bA} 1}$ \\
\hline 190 & $2,05 \pm 0,10^{\mathrm{aA} 1}$ & $1,88 \pm 0,09^{\mathrm{bAB} 1}$ & $1,98 \pm 0,13^{\mathrm{abA} 1}$ & $1,96 \pm 0,08^{\mathrm{abA} 1}$ \\
\hline 220 & $2,00 \pm 0,11^{\mathrm{abA} 1}$ & $1,98 \pm 0,11^{\mathrm{abA} 1}$ & $1,92 \pm 0,12^{\mathrm{bA} 1}$ & $2,24 \pm 0,45^{\mathrm{aA} 1}$ \\
\hline \multicolumn{5}{|l|}{ Com vapor } \\
\hline 160 & $2,00 \pm 0,13^{\mathrm{aAB} 1}$ & $1,78 \pm 0,09^{\mathrm{aB} 1}$ & $1,82 \pm 0,10^{\mathrm{aA} 1}$ & $1,81 \pm 0,25^{\mathrm{aB} 1}$ \\
\hline 190 & $2,07 \pm 0,16^{\mathrm{aA} 1}$ & $1,98 \pm 0,14^{\mathrm{aA} 1}$ & $1,93 \pm 0,13^{\mathrm{aA} 1}$ & $1,76 \pm 0,04^{\mathrm{bB} 2}$ \\
\hline 220 & $1,90 \pm 0,12^{\mathrm{abB} 1}$ & $1,98 \pm 0,08^{\mathrm{aA} 1}$ & $1,80 \pm 0,13^{\mathrm{bA} 1}$ & $2,03 \pm 0,12^{\mathrm{aA} 1}$ \\
\hline \multicolumn{5}{|c|}{$\begin{array}{l}\text { *Letras minúsculas diferentes na mesma linha indicam diferença estatística entre os tempos de } \\
\text { assamento para a mesma condição de vapor e temperatura; } \\
\text { **Letras maiúsculas diferentes na mesma coluna indicam diferença estatística entre as diferentes } \\
\text { temperaturas de assamento para uma mesma condição de vapor e tempo; } \\
\text { ***Números diferentes na mesma coluna para a mesma condição de tempo e temperatura, indicam } \\
\text { diferença estatística entre os tratamentos com e sem vapor. } \\
\text { Fonte: Próprio autor, } 2018 .\end{array}$} \\
\hline
\end{tabular}


Assim como a luminosidade, os valores de croma $\mathrm{a}^{*}$ também variam dependendo do provador e de sua localização. Na Turquia, por exemplo, foram encontrados valores de $-2,02$ (ÖZKAYA; BAUMGARTNER; ÖZKAYA, 2018) e -1,03 \pm 0,2 (ERBAS et al., 2012) . Já na Nova Zelândia, Fu et al., (2018) produziram pães com croma a* referente ao miolo um pouco mais escura $(0.67 \pm 0.14)$, porém, ainda menor do que o obtido neste trabalho. Todos os trabalhos da literatura avaliaram pão produzidos com farinha de trigo.

Os resultados de croma $a^{*}$ obtidas para as crostas dos pães assados sob as diferentes condições variou entre 3,08 a 16,77, como podem ser observados na Tabela 8.

Para as temperaturas de $160^{\circ} \mathrm{C}$ e $190^{\circ} \mathrm{C}$ nos tratamentos com e sem introdução de vapor, pode-se verificar que o aumento no tempo de assamento resultou em aumento nos valores de $a^{*}$ da crosta do pão. O mesmo resultado também foi obtido por Park e Baik (2007).

Em relação ao aumento da temperatura de assamento pode-se observar aumento significativo dos valores de croma $\mathrm{a}^{*}$, até 15 minutos de assamento; para o tempo de 20 minutos observou-se uma redução dos valores. Erbas et al. (2012) obtiveram aumento do valor de croma $\mathrm{a}^{*}$ da crosta do pão conforme elevaram-se as temperaturas de assamento.

Em relação ao uso ou não de vapor, pode-se observar que a introdução de vapor no assamento provocou aumento significativo nos valores de croma $\mathrm{a}^{*}$ da crosta dos pães.

$\mathrm{Na}$ literatura observa-se uma grande variação nos valores de croma a* obtidos para a crosta dos pães. Erbas et al. (2012) encontraram valores entre 13,01 e 5,63, Park e Baik (2007) entre 14,5 e 4,8 e Shittu, Raji e Sanni (2007) entre 14,9 e 3,18. Estas respostas indicam que os resultados deste trabalho estão coerentes com a literatura, porém devido à grande variação aceitável para o aspecto de croma $a^{*}$, não é possível definir um melhor tempo de assamento baseado neste critério.

Quando comparado os resultados do miolo e da crosta do pão, o tempo de assamento influenciou mais a crosta do que o miolo, principalmente no tratamento em que foi adicionado vapor. 
Tabela 8 - $\quad$ Resultados de croma a* da crosta dos pães assados com e sem introdução de vapor nas temperaturas de 160,190 e $220^{\circ} \mathrm{C}$, para os tempos de $9,12,15$ e 20 minutos.

\begin{tabular}{|c|c|c|c|c|}
\hline \multirow{2}{*}{ Temperatura $\left({ }^{\circ} \mathbf{C}\right)$} & \multicolumn{4}{|c|}{ Tempo (min) } \\
\hline & 9 & 12 & 15 & 20 \\
\hline \multicolumn{5}{|l|}{ Sem vapor } \\
\hline 160 & $3,98 \pm 0,16^{\mathrm{dC} 1}$ & $4,92 \pm 0,55^{\mathrm{cB} 1}$ & $5,97 \pm 0,37^{\mathrm{bB} 2}$ & $8,21 \pm 0,48^{\mathrm{aC} 2}$ \\
\hline 190 & $7,95 \pm 0,73^{\mathrm{cB} 2}$ & $10,48 \pm 1,06^{\mathrm{bA} 2}$ & $11,66 \pm 0,89^{\mathrm{abA} 2}$ & $12,35 \pm 0,78^{\mathrm{aA} 2}$ \\
\hline 220 & $12,18 \pm 1,12^{\mathrm{aA} 2}$ & $11,16 \pm 0,72^{\mathrm{bA} 2}$ & $11,00 \pm 0,52^{\mathrm{bA} 2}$ & $10,31 \pm 0,43^{\mathrm{bB} 2}$ \\
\hline \multicolumn{5}{|l|}{ Com vapor } \\
\hline 160 & $3,08 \pm 0,15^{\mathrm{dC} 2}$ & $4,58 \pm 0,26^{\mathrm{cC} 1}$ & $6,87 \pm 0,73^{\mathrm{bB} 1}$ & $12,08 \pm 0,56^{\mathrm{aC} 1}$ \\
\hline 190 & $9,99 \pm 0,58^{\mathrm{dB} 1}$ & $13,14 \pm 0,71^{\mathrm{cB} 1}$ & $14,89 \pm 0,54^{\mathrm{bA} 1}$ & $16,77 \pm 0,74^{\mathrm{aA} 1}$ \\
\hline 220 & $14,86 \pm 0,71^{\mathrm{bcA} 1}$ & $16,63 \pm 0,60^{\mathrm{aA} 1}$ & $15,55 \pm 0,85^{\mathrm{bA} 1}$ & $14,36 \pm 0,89^{\mathrm{cB} 1}$ \\
\hline \multicolumn{5}{|c|}{$\begin{array}{l}\text { *Letras minúsculas diferentes na mesma linha indicam diferença estatística entre os tempos de } \\
\text { assamento para a mesma condição de vapor e temperatura; } \\
\text { **Letras maiúsculas diferentes na mesma coluna indicam diferença estatística entre as diferentes } \\
\text { temperaturas de assamento para uma mesma condição de vapor e tempo; } \\
\text { ***Números diferentes na mesma coluna para a mesma condição de tempo e temperatura, indicam } \\
\text { diferença estatística entre os tratamentos com e sem vapor. } \\
\text { Fonte: Próprio autor, } 2018 .\end{array}$} \\
\hline
\end{tabular}

\section{Croma b*}

Os resultados de croma $b^{*}$ obtidos para o miolo dos pães assados sob as diferentes condições variaram entre 20,73 a 23,19, como podem ser observados na Tabela 9.

O aumento do tempo de assamento não apresentou efeito significativo nos valores de croma $b^{*}$ dos miolos, independente do uso ou não de vapor.

O aumento da temperatura de assamento também não apresentou efeito significativo nos valores de croma $b^{*}$ dos miolos, para a condição sem vapor. Por outro lado, para a condição com vapor o aumento da temperatura de assamento provocou redução significativa nos valores de croma $b^{*}$ dos miolos.

Com exceção dos tratamentos a $160^{\circ} \mathrm{C}$ por 15 minutos e $220^{\circ} \mathrm{C}$ por 9 minutos, não foi verificado efeito significativo da introdução ou não de vapor sob o croma $b^{*}$ dos miolos.

Erbas et al. (2012) produziram pães com croma b* do miolo de 12,4 $\pm 0,8$, Özkaya; Baumgartner; Özkaya (2018) obtiveram valores de croma b* igual a 15,05 e FU et al. (2018) produziu pães com croma $b^{*}$ igual a $15.29 \pm 0.48$. Os valores obtidos na literatura são referentes a pães produzidos com farinha de trigo, porém, estão abaixo dos encontrados neste 
trabalho. Mais uma vez, não é possível considerar um parâmetro de cor certo ou errado, uma vez que sua aceitação irá depender de diversos fatores como preferências pessoais e culturais do provador e localização geográfica.

Tabela 9 - Resultados de croma $b^{*}$ do miolo dos pães assados com e sem introdução de vapor nas temperaturas de 160,190 e $220^{\circ} \mathrm{C}$, para os tempos de $9,12,15$ e 20 minutos.

\begin{tabular}{|c|c|c|c|c|}
\hline \multirow{2}{*}{ Temperatura $\left({ }^{\circ} \mathbf{C}\right)$} & \multicolumn{4}{|c|}{ Tempo (min) } \\
\hline & 9 & 12 & 15 & 20 \\
\hline \multicolumn{5}{|l|}{ Sem vapor } \\
\hline 160 & $21,27 \pm 1,30^{\mathrm{aA} 1}$ & $21,13 \pm 1,23^{\mathrm{aA} 1}$ & $21,69 \pm 1,40^{\mathrm{aA} 2}$ & $21,30 \pm 1,58^{\mathrm{aA} 1}$ \\
\hline 190 & $22,09 \pm 0,64^{\mathrm{aA} 1}$ & $21,57 \pm 0,90^{\mathrm{aA} 1}$ & $22,01 \pm 0,77^{\mathrm{aA} 1}$ & $21,93 \pm 0,81^{\mathrm{aA} 1}$ \\
\hline 220 & $21,64 \pm 0,57^{\mathrm{aA} 1}$ & $21,25 \pm 0,96^{\mathrm{aA} 1}$ & $21,34 \pm 0,75^{\mathrm{aA} 1}$ & $21,53 \pm 0,85^{\mathrm{aA} 1}$ \\
\hline \multicolumn{5}{|l|}{ Com vapor } \\
\hline 160 & $22,20 \pm 1,51^{\mathrm{aA} 1}$ & $22,40 \pm 1,33^{\mathrm{aA} 1}$ & $23,19 \pm 1,56^{\mathrm{aA} 1}$ & $22,63 \pm 1,32^{\mathrm{aA} 1}$ \\
\hline 190 & $22,11 \pm 0,92^{\mathrm{aA} 1}$ & $21,75 \pm 1,07^{\mathrm{aAB} 1}$ & $21,91 \pm 1,01^{\mathrm{aB} 1}$ & $21,84 \pm 0,99^{\mathrm{aAB} 1}$ \\
\hline 220 & $20,73 \pm 0,92^{\mathrm{aB} 2}$ & $21,20 \pm 0,72^{\mathrm{aB} 1}$ & $21,19 \pm 0,91^{\mathrm{aB} 1}$ & $21,40 \pm 1,04^{\mathrm{aB} 1}$ \\
\hline
\end{tabular}

Os resultados de croma $b^{*}$ obtidos para a crosta dos pães assados sob as diferentes condições variaram entre 18,25 a 34,63, como podem ser observados na Tabela 10.

O aumento do tempo de assamento provocou aumento significativo nos valores de croma b* da crosta dos pães assados à 160 e $190^{\circ} \mathrm{C}$, com ou sem vapor. Por outro lado, para o assamento a $220^{\circ} \mathrm{C}$ o aumento do tempo de assamento provocou redução significativa nos valores de croma $b^{*}$ da crosta dos pães. Park e Baik, (2007) verificaram aumento nos valores de $b^{*}$ da crosta de pães assados à $218^{\circ} \mathrm{C}$ em função do aumento do tempo de assamento até 12 minutos, para tempos superiores os autores reportaram redução nos valores de croma b*.

Quanto a elevação da temperatura, não foi encontrado uma relação clara entre o aumento da temperatura e os valores de croma b* na crosta. Erbas et al. (2012) verificaram que temperaturas de assamento mais baixas produziram pães com maiores valores de $b^{*}$, este resultado foi obtido neste trabalho para as condições com e sem vapor por 9 minutos. 
Em relação ao uso ou não de vapor, pode-se observar que a introdução de vapor no assamento provocou aumento significativo nos valores de croma $b^{*}$ da crosta dos pães.

$\mathrm{Na}$ literatura observa-se valores variados para o croma $b^{*}$ da crosta de pães produzidos com farinha de trigo. Erbas et al. (2012) produziram pães com valores de croma b* entre 23,99 e 20,79, Park e Baik, (2007) entre 33 e 25,9 e Shittu, Raji e Sanni (2007) entre 32,27 e 15,18. Sendo assim, diferentes condições de assamento podem fornecer diferentes respostas quanto ao critério de cor croma $b^{*}$ da crosta. Logo, não é possível utilizar nenhum dos critérios de cor para definir o melhor tempo de assamento. Porém, estes dados são importantes para caracterizar o produto.

Tabela 10 - Resultados de croma b* da crosta dos pães assados com e sem introdução de vapor nas temperaturas de 160,190 e $220^{\circ} \mathrm{C}$, para os tempos de $9,12,15$ e 20 minutos.

\begin{tabular}{lcccc}
\hline \multirow{2}{*}{ Temperatura $\left({ }^{\circ} \mathbf{C}\right)$} & \multicolumn{4}{c}{ Tempo (min) } \\
\cline { 2 - 5 } & 9 & 12 & 15 & 20 \\
\hline Sem vapor & & & & \\
$\mathbf{1 6 0}$ & $22,27 \pm 0,93^{\mathrm{dC} 2}$ & $24,62 \pm 0,42^{\mathrm{cA} 2}$ & $26,85 \pm 0,67^{\mathrm{bB} 2}$ & $28,39 \pm 1,28^{\mathrm{aB} 2}$ \\
$\mathbf{1 9 0}$ & $24,00 \pm 1,52^{\mathrm{cB} 2}$ & $25,67 \pm 0,81^{\mathrm{bA} 2}$ & $29,64 \pm 1,03^{\mathrm{aA} 2}$ & $30,33 \pm 0,89^{\mathrm{aA} 2}$ \\
$\mathbf{2 2 0}$ & $26,73 \pm 0,72^{\mathrm{aA} 2}$ & $25,48 \pm 0,93^{\mathrm{bA} 2}$ & $26,52 \pm 0,55^{\mathrm{abB} 2}$ & $21,99 \pm 1,29^{\mathrm{cC} 1}$ \\
\hline $\mathbf{C o m}$ vapor & & & & \\
$\mathbf{1 6 0}$ & $24,22 \pm 0,60^{\mathrm{dC} 1}$ & $28,20 \pm 1,54^{\mathrm{cB} 1}$ & $34,63 \pm 1,38^{\mathrm{aA} 1}$ & $31,95 \pm 1,79^{\mathrm{bA} 1}$ \\
$\mathbf{1 9 0}$ & $30,99 \pm 0,92^{\mathrm{bB} 1}$ & $30,30 \pm 1,91^{\mathrm{bA} 1}$ & $34,43 \pm 1,21^{\mathrm{aA} 1}$ & $34,42 \pm 2,74^{\mathrm{aA} 1}$ \\
$\mathbf{2 2 0}$ & $33,03 \pm 1,91^{\mathrm{aA} 1}$ & $28,34 \pm 0,99^{\mathrm{bB} 1}$ & $28,34 \pm 0,45^{\mathrm{bB} 1}$ & $18,25 \pm 1,79^{\mathrm{cB} 2}$ \\
\hline
\end{tabular}

*Letras minúsculas diferentes na mesma linha indicam diferença estatística entre os tempos de assamento para a mesma condição de vapor e temperatura;

**Letras maiúsculas diferentes na mesma coluna indicam diferença estatística entre as diferentes temperaturas de assamento para uma mesma condição de vapor e tempo;

***Números diferentes na mesma coluna para a mesma condição de tempo e temperatura, indicam diferença estatística entre os tratamentos com e sem vapor.

Fonte: Próprio autor, 2018.

Ao comparar os resultados da crosta com os obtidos no miolo do pão, nota-se que o vapor tem maior influência na formação da cor da crosta do pão do que do miolo.

A formação da cor é resultado da reação de Maillard que depende, entre outros fatores, das condições de assamento (AHRNÉ et al., 2007). Como pode ser verificado na seção 5.2, cada condição de temperatura e vapor utilizada durante o assamento fornece uma taxa de aquecimento específica e segundo Ahrné et al. (2007) a taxas de aquecimento modifica a cor 
do pão, por este motivo ocorreram modificações nos parâmetros de cor de acordo com a condição de assamento utilizada.

\subsubsection{Altura}

Os resultados de altura final dos pães após assamento sob diferentes condições de tempo, temperatura e vapor variaram entre 3,8 a $4,5 \mathrm{~cm}$, como podem ser observados na Tabela 11.

Tabela 11 - Resultados da altura final $(\mathrm{cm})$ dos pães assados com e sem introdução de vapor nas temperaturas de 160,190 e $220^{\circ} \mathrm{C}$, para os tempos de 9,12 , 15 e 20 minutos.

\begin{tabular}{llllll}
\hline \multirow{2}{*}{ Temperatura $\left({ }^{\circ} \mathbf{C}\right)$} & \multicolumn{5}{c}{ Tempo (min) } \\
\cline { 2 - 6 } & 9 & 12 & 15 & 20 \\
\hline
\end{tabular}

\section{Sem vapor}

\begin{tabular}{lllll}
160 & $4,2 \pm 0,2^{\mathrm{aA} 1}$ & $4,1 \pm 0,4^{\mathrm{aB} 1}$ & $4,1 \pm 0,3^{\mathrm{aA} 1}$ & $4,2 \pm 0,2^{\mathrm{aA} 1}$ \\
$\mathbf{1 9 0}$ & $4,2 \pm 0,4^{\mathrm{aA} 1}$ & $4,1 \pm 0,3^{\mathrm{aB} 1}$ & $4,4 \pm 0,5^{\mathrm{aA} 1}$ & $4,3 \pm 0,3^{\mathrm{aA} 1}$ \\
$\mathbf{2 2 0}$ & $4,3 \pm 0,5^{\mathrm{aA} 1}$ & $4,5 \pm 0,3^{\mathrm{aA} 1}$ & $4,2 \pm 0,3^{\mathrm{aA} 1}$ & $4,4 \pm 0,2^{\mathrm{aA} 1}$ \\
\hline
\end{tabular}

\section{Com vapor}

\begin{tabular}{lllll}
$\mathbf{1 6 0}$ & $3,8 \pm 0,2^{\mathrm{aA} 2}$ & $3,8 \pm 0,3^{\mathrm{aA} 1}$ & $4,0 \pm 0,3^{\mathrm{aA} 1}$ & $4,0 \pm 0,2^{\mathrm{aA} 1}$ \\
$\mathbf{1 9 0}$ & $4,1 \pm 0,5^{\mathrm{aA} 1}$ & $4,0 \pm 0,5^{\mathrm{aA} 1}$ & $4,3 \pm 0,6^{\mathrm{aA} 1}$ & $3,9 \pm 0,4^{\mathrm{aA} 2}$ \\
$\mathbf{2 2 0}$ & $4,2 \pm 0,2^{\mathrm{aA} 1}$ & $4,1 \pm 0,2^{\mathrm{aA} 2}$ & $4,1 \pm 0,2^{\mathrm{aA} 1}$ & $4,1 \pm 0,3^{\mathrm{aA} 2}$ \\
\hline
\end{tabular}

*Letras minúsculas diferentes na mesma linha indicam diferença estatística entre os tempos de assamento para a mesma condição de vapor e temperatura;

**Letras maiúsculas diferentes na mesma coluna indicam diferença estatística entre as diferentes temperaturas de assamento para uma mesma condição de vapor e tempo;

***Números diferentes na mesma coluna para a mesma condição de tempo e temperatura, indicam diferença estatística entre os tratamentos com e sem vapor.

Fonte: Próprio autor, 2018.

O aumento do tempo de assamento não apresentou efeito significativo sobre a altura final dos pães para as três temperaturas avaliadas. Da mesma forma, o aumento da temperatura de assamento não apresentou influência significativa na resposta altura, com exceção para a temperatura de $220^{\circ} \mathrm{C}$ tempo 12 minutos sem introdução de vapor, que apresentou maior altura quando comparado com as outras temperaturas no mesmo tempo.

Em relação a introdução, ou não, de vapor, os pães assados sem adição de vapor apresentaram altura significativamente superior para as seguintes condições: $160^{\circ} \mathrm{C}$ por 9 
minutos, $220^{\circ} \mathrm{C}$ por 12 minutos, $190^{\circ} \mathrm{C}$ e $220^{\circ} \mathrm{C}$ ambos por 20 minutos. Todas as outras condições não diferiram estatisticamente. Segundo Vasafi; Hamdami e Keramat (2019) a altura do pão aumenta devido a evaporação do teor de umidade durante o assamento. Ao introduzir vapor forma-se uma superfície umidade (LE-BAIL et al., 2011) e a taxa de aquecimento da massa é menor (seção 5.2) em comparação com os pães assados sem introdução de vapor, o que pode justificar a menor altura encontrada para os tratamentos com introdução de vapor.

\subsubsection{Perda de água durante o assamento}

O perfil de perda de água durante o assamento variou entre 10,87 a $27,57 \%$, como pode ser observado na Tabela 12 .

O aumento do tempo e da temperatura de assamento provocaram aumento significativo da perda de água dos pães durante o assamento. Em relação a adição, ou não, de vapor, para o tratamento a $220^{\circ} \mathrm{C}$, ocorreu menor perda de água para os tratamentos com introdução de vapor. Sendo assim, o vapor pode reduzir a perda de água nas condições de assamento mais extremas, com elevadas temperaturas.

Zhang et al. (2017) encontraram uma perda de água no pão no final do processo de assamento que variou de $9,2 \pm 1,1$ a $13 \pm 3,1 \%$. Wagner et al. (2008) também avaliaram a perda de água durante o assamento e obtiveram valores entre 10 a $12 \%$ de perda de água. Vouris et al. (2018) avaliaram a perda de peso dos pães durante o assamento e encontraram 18,06 \% de perda. Vanin et al. (2017) verificaram uma perda de água que varia de $-3,1 \%$ para um aumento de $20 \%$ em relação a temperatura de referência e $+4,9 \%$ para uma redução em $20 \%$ em relação a temperatura de referência. Os trabalhos da literatura utilizaram diferentes temperaturas de assamento o que pode ter causado a diferença no teor de água perdido nos pães.

Não é viável economicamente para a indústria de alimentos produzirem pães com um elevado teor de perda de água durante o assamento uma vez que os pães são comercializados com base no peso do produto final, sendo assim, quanto maior a quantidade de água presente no pão maior será seu peso final e por isso maior será o lucro da empresa. Logo, devem-se utilizar as condições que forneçam menores perdas de água. 
Tabela 12 - Resultados da perda de água (gramas de água/100 gramas de pão) em relação a massa inicial dos pães assados com e sem introdução de vapor nas temperaturas de 160, 190 e $220^{\circ} \mathrm{C}$, para os tempos de $9,12,15$ e 20 minutos.

\begin{tabular}{lcccc}
\hline \multirow{2}{*}{ Temperatura $\left({ }^{\circ} \mathbf{C}\right)$} & \multicolumn{4}{c}{ Tempo (min) } \\
\cline { 2 - 5 } & 9 & 12 & 15 & 20 \\
\hline Sem vapor & & & & \\
$\mathbf{1 6 0}$ & $10,87 \pm 0,41^{\mathrm{dC} 2}$ & $13,52 \pm 0,73^{\mathrm{cC} 1}$ & $16,02 \pm 0,43^{\mathrm{bC} 1}$ & $19,58 \pm 0,64^{\mathrm{aC} 1}$ \\
$\mathbf{1 9 0}$ & $12,22 \pm 0,83^{\mathrm{dB} 1}$ & $16,12 \pm 0,60^{\mathrm{cB} 1}$ & $18,91 \pm 0,42^{\mathrm{bB} 1}$ & $23,23 \pm 0,63^{\mathrm{aB} 1}$ \\
$\mathbf{2 2 0}$ & $16,12 \pm 0,55^{\mathrm{dA} 1}$ & $20,40 \pm 1,43^{\mathrm{cA} 1}$ & $23,58 \pm 0,44^{\mathrm{bA} 1}$ & $27,57 \pm 0,65^{\mathrm{aA} 1}$ \\
\hline $\mathbf{C o m}$ vapor & & & & \\
$\mathbf{1 6 0}$ & $11,99 \pm 1,47^{\mathrm{dB} 1}$ & $13,44 \pm 0,51^{\mathrm{cC} 1}$ & $15,73 \pm 0,59^{\mathrm{bC} 1}$ & $19,31 \pm 0,46^{\mathrm{aC} 1}$ \\
$\mathbf{1 9 0}$ & $12,77 \pm 0,99^{\mathrm{dB} 1}$ & $16,34 \pm 0,58^{\mathrm{cB} 1}$ & $19,02 \pm 1,50^{\mathrm{bB} 1}$ & $23,55 \pm 1,04^{\mathrm{aB} 1}$ \\
$\mathbf{2 2 0}$ & $14,58 \pm 1,05^{\mathrm{dA} 2}$ & $18,57 \pm 0,99^{\mathrm{cA} 2}$ & $21,83 \pm 1,10^{\mathrm{bA} 2}$ & $26,57 \pm 1,14^{\mathrm{aA} 2}$ \\
\hline
\end{tabular}

*Letras minúsculas diferentes na mesma linha indicam diferença estatística entre os tempos de assamento para a mesma condição de vapor e temperatura;

**Letras maiúsculas diferentes na mesma coluna indicam diferença estatística entre as diferentes temperaturas de assamento para uma mesma condição de vapor e tempo;

***Números diferentes na mesma coluna para a mesma condição de tempo e temperatura, indicam diferença estatística entre os tratamentos com e sem vapor.

Fonte: Próprio autor, 2018.

\subsubsection{Volume específico}

Os resultados de volume específico variaram entre 2,82 a $3,65 \mathrm{ml} / \mathrm{g}$, como apresentados na Tabela 13 .

Observou-se que o aumento do tempo acarretou em um efeito significativo sobre o volume específico dos pães durante o assamento. Para os pães assados sem introdução de vapor a $220^{\circ} \mathrm{C}$ e para o tratamento com vapor a $160^{\circ} \mathrm{C}$ e $190^{\circ} \mathrm{C}$, o volume do pão foi maior conforme os pães permaneceram mais tempo no forno. As outras condições não apresentaram diferença significativa.

Em relação às diferentes temperaturas, para os pães assados sem vapor, não foi possível estabelecer uma relação clara sobre o efeito do aumento de temperatura no volume específico. Já, para os pães assados com vapor, o aumento da temperatura de assamento provocou aumento nos valores de volume específico dos pães.

Quando comparado os tratamentos com e sem vapor, sob mesma condição de tempo e temperatura de assamento, há diferença estatística entre os tratamentos, apenas para os pães 
assados por 15 e 20 minutos, sendo que o tratamento a $190^{\circ} \mathrm{C}$ com introdução de vapor apresentou maior volume específico.

Rebellato et al. (2017) trabalharam com pães com volume específico de 4,85 $\pm 0,11$ $\mathrm{ml} / \mathrm{g}$, Park e Baik (2007) obtiveram volume específico entre 3,8 a 4,5 ml/g e Özkaya, Baumgartner e Özkaya (2018) volume específico de 3,62 ml/g. Sendo assim, os valores da literatura estão acima do encontrado em todas as condições avaliadas neste trabalho, por isso, é indicado utilizar as condições que fornecem o maior volume.

Segundo Shittu et al. (2007) diferentes tempos e temperaturas de assamento podem provocar variações na taxa de aquecimento e nas propriedades de gelatinização do amido e por isso ocorrem mudanças no volume do pão. O que justifica o fato da elevação do tempo e da temperatura terem fornecido maiores volumes aos pães avaliados neste trabalho.

Tabela 13 - Resultados do volume específico (ml/g) dos pães assados com e sem introdução de vapor nas temperaturas de 160,190 e $220^{\circ} \mathrm{C}$, para os tempos de $9,12,15$ e 20 minutos.

\begin{tabular}{lcccc}
\hline \multirow{2}{*}{ Temperatura $\left({ }^{\circ} \mathbf{C}\right)$} & \multicolumn{4}{c}{ Tempo (min) } \\
\cline { 2 - 5 } Sem vapor & 9 & 12 & 15 & 20 \\
$\mathbf{1 6 0}$ & $3,24 \pm 0,38^{\mathrm{aA} 1}$ & $3,39 \pm 0,43^{\mathrm{aA} 1}$ & $3,53 \pm 0,43^{\mathrm{aA} 1}$ & $3,65 \pm 0,62^{\mathrm{aA} 1}$ \\
$\mathbf{1 9 0}$ & $2,82 \pm 0,16^{\mathrm{aB} 1}$ & $2,85 \pm 0,18^{\mathrm{aB} 1}$ & $2,87 \pm 0,17^{\mathrm{aB} 2}$ & $2,96 \pm 0,17^{\mathrm{aB} 2}$ \\
$\mathbf{2 2 0}$ & $3,19 \pm 0,23^{\mathrm{bA} 1}$ & $3,25 \pm 0,28^{\mathrm{abAB} 1}$ & $3,48 \pm 0,25^{\mathrm{abA} 1}$ & $3,61 \pm 0,26^{\mathrm{aA} 1}$ \\
\hline $\mathbf{C o m}$ vapor & & & & \\
$\mathbf{1 6 0}$ & $2,95 \pm 0,19^{\mathrm{cB} 1}$ & $3,06 \pm 0,06^{\mathrm{bcB} 1}$ & $3,13 \pm 0,05^{\mathrm{abB} 2}$ & $3,22 \pm 0,11^{\mathrm{aB} 1}$ \\
$\mathbf{1 9 0}$ & $2,93 \pm 0,12^{\mathrm{cB} 1}$ & $3,01 \pm 0,13^{\mathrm{bcB} 1}$ & $3,16 \pm 0,20^{\mathrm{abB} 1}$ & $3,28 \pm 0,19^{\mathrm{aB} 1}$ \\
$\mathbf{2 2 0}$ & $3,25 \pm 0,24^{\mathrm{aA} 1}$ & $3,40 \pm 0,32^{\mathrm{aA} 1}$ & $3,48 \pm 0,38^{\mathrm{aA} 1}$ & $3,61 \pm 0,32^{\mathrm{aA} 1}$ \\
\hline
\end{tabular}

*Letras minúsculas diferentes na mesma linha indicam diferença estatística entre os tempos de assamento para a mesma condição de vapor e temperatura;

**Letras maiúsculas diferentes na mesma coluna indicam diferença estatística entre as diferentes temperaturas de assamento para uma mesma condição de vapor e tempo;

***Números diferentes na mesma coluna para a mesma condição de tempo e temperatura, indicam diferença estatística entre os tratamentos com e sem vapor.

Fonte: Próprio autor, 2018. 


\subsubsection{Análise de dureza}

Os resultados de dureza obtidos para os pães assados sob as diferentes condições de tempo, temperatura e utilização ou não de vapor variaram entre 0,314 a $0,654 \mathrm{~kg}$, como podem ser observados na Tabela 14.

O aumento do tempo de assamento provocou aumento significativo na dureza dos pães para ambas as condições, com e sem vapor. Em relação ao aumento da temperatura, não foi verificado um efeito claro. Quanto a introdução ou não de vapor, não houve diferença estatística entre os tratamentos.

Tabela 14 - Resultados da dureza ( $\mathrm{kg}$ ) dos pães assados com e sem introdução de vapor nas temperaturas de 160,190 e $220^{\circ} \mathrm{C}$, para os tempos de $9,12,15$ e 20 minutos.

\begin{tabular}{lcccc}
\hline \multirow{2}{*}{$\begin{array}{l}\text { Temperatura } \\
\left({ }^{\circ} \mathbf{C}\right)\end{array}$} & 9 & 12 & 15 & 20 \\
\cline { 2 - 5 } Sem vapor & & & & \\
\hline $\mathbf{1 6 0}$ & $0,324 \pm 0,073^{\mathrm{bB} 1}$ & $0,343 \pm 0,051^{\mathrm{bB} 1}$ & $0,406 \pm 0,084^{\mathrm{abB} 1}$ & $0,455 \pm 0,049^{\mathrm{aB} 1}$ \\
$\mathbf{1 9 0}$ & $0,447 \pm 0,074^{\mathrm{bA} 1}$ & $0,496 \pm 0,062^{\mathrm{bA} 1}$ & $0,501 \pm 0,039^{\mathrm{bA} 1}$ & $0,654 \pm 0,095^{\mathrm{aA} 1}$ \\
$\mathbf{2 2 0}$ & $0,422 \pm 0,092^{\mathrm{bAB} 1}$ & $0,447 \pm 0,143^{\mathrm{bAB} 1}$ & $0,512 \pm 0,075^{\mathrm{abA} 1}$ & $0,604 \pm 0,136^{\mathrm{aA} 1}$ \\
\hline Com vapor & & & & \\
$\mathbf{1 6 0}$ & $0,314 \pm 0,041^{\mathrm{cC} 1}$ & $0,399 \pm 0,050^{\mathrm{bA} 1}$ & $0,436 \pm 0,055^{\mathrm{abB} 1}$ & $0,490 \pm 0,051^{\mathrm{aB} 1}$ \\
$\mathbf{1 9 0}$ & $0,443 \pm 0,045^{\mathrm{bA} 1}$ & $0,445 \pm 0,090^{\mathrm{bA} 1}$ & $0,524 \pm 0,116^{\mathrm{abAB} 1}$ & $0,622 \pm 0,131^{\mathrm{aA} 1}$ \\
$\mathbf{2 2 0}$ & $0,384 \pm 0,033^{\mathrm{bB} 1}$ & $0,407 \pm 0,049^{\mathrm{bA} 1}$ & $0,555 \pm 0,090^{\mathrm{aA} 1}$ & $0,565 \pm 0,089^{\mathrm{aAB} 1}$ \\
\hline
\end{tabular}

*Letras minúsculas diferentes na mesma linha indicam diferença estatística entre os tempos de assamento para a mesma condição de vapor e temperatura;

**Letras maiúsculas diferentes na mesma coluna indicam diferença estatística entre as diferentes temperaturas de assamento para uma mesma condição de vapor e tempo;

***Números diferentes na mesma coluna para a mesma condição de tempo e temperatura, indicam diferença estatística entre os tratamentos com e sem vapor.

Fonte: Próprio autor, 2018.

Mezaize et al. (2010) trabalharam com dureza do miolo de 0,18 $\pm 0,01 \mathrm{~kg}$ para pão sem glúten assado a $200^{\circ} \mathrm{C}$ por 40 minutos. Özkaya, Baumgartner e Özkaya (2018) produziram pão utilizando farelo de trigo assado a $220^{\circ} \mathrm{C}$ por 25 minutos e encontraram dureza de 0,260 kg e Bárcenas e Rosell (2005) avaliaram a dureza dos pães produzidos com farinha de trigo assados a $195^{\circ} \mathrm{C}$ por 16 minutos e obtiveram um valor de $0,2827 \pm 0,0249 \mathrm{~kg}$. Os valores reportados na literatura são menores do que os observados neste trabalho, 
provavelmente devido aos diferentes ingredientes utilizados na formulação ou as diferentes condições de tempo e temperatura de assamento.

As diferentes condições de assamento podem fornecer resultados distintos em termos de propriedades de gelatinização do amido, que irá modificar as propriedades viscoelásticas da massa (PYLER, E. J; GORTON, 2008) e aumentar a dureza do pão (GISSLEN, 1895), o que pode justificar a maior dureza encontrada em pães assados por longos tempos.

\subsubsection{Resumo dos efeitos}

A Tabela 15 apresenta um resumo dos efeitos das diferentes condições de assamento (tempo, temperatura e utilização de vapor) sobre as diferentes respostas avaliadas.

O aumento do tempo de assamento provocou um aumento nos parâmetros de cor cromas $\mathrm{a}^{*}$ e $\mathrm{b}^{*}$ referentes à crosta do pão, perda de água, volume específico e dureza, porém, reduziu a luminosidade da crosta e do miolo e não influenciou nos parâmetros de cor cromas $a^{*}$ e b* do miolo e na altura dos pães.

Em relação ao aumento da temperatura, verifica-se que este processo provocou um aumento dos parâmetros de cor cromas a*, perda de água, volume dos pães produzidos com vapor, porém reduziu a luminosidade da crosta e croma $b^{*}$ do miolo. A cor do pão é um parâmetro muito subjetivo por isso foi utilizado apenas com a finalidade de caracterização da amostra.

A adição de vapor durante o assamento provocou aumento nos parâmetros de cor cromas $\mathrm{a}^{*}$ e $\mathrm{b}^{*}$ da crosta e volume específico, porém reduziu a luminosidade $\mathrm{L}^{*}$ da crosta e para alguns casos reduziu a altura final dos pães e a perda de água. A redução na altura foi pequena, ocorreu apenas em algumas condições de assamento e pode estar relacionada a fatores externos como diferentes condições de temperaturas ambiente e umidade do ar devido a produção dos pães ter sido realizada em dias diferentes. Quanto a perda de água, é esperado que ao introduzir vapor de água no assamento os pães apresentem menor perda. Isso ocorreu para as condições de assamento mais intensas $\left(220^{\circ} \mathrm{C}\right)$. É necessário, portanto, que seja introduzido vapor para viabilizar a produção principalmente quando a assamento ocorre em condições de altas temperaturas. 
Tabela 15 - Efeito do tempo, temperatura e umidade do forno sobre as respostas de cor, altura, perda de água, volume especifico e dureza dos pães.

\begin{tabular}{|c|c|c|c|c|}
\hline \multirow{2}{*}{\multicolumn{2}{|c|}{ Resposta }} & \multicolumn{3}{|c|}{ Aumento } \\
\hline & & Tempo & Temperatura & Vapor \\
\hline \multirow{3}{*}{ Crosta } & $\mathrm{L}^{*}$ & - & - & - \\
\hline & $a^{*}$ & + & + & + \\
\hline & $b^{*}$ & $+(160 ; 190) /-(220)$ & 0 & + \\
\hline \multirow{3}{*}{ Miolo } & $\mathrm{L}^{*}$ & - & 0 & 0 \\
\hline & $a^{*}$ & 0 & $0+$ & 0 \\
\hline & $b^{*}$ & 0 & $0-$ & 0 \\
\hline \multicolumn{2}{|l|}{ Altura } & 0 & 0 & $0-$ \\
\hline \multicolumn{2}{|c|}{ Perda de água } & + & + & $0-$ \\
\hline \multicolumn{2}{|c|}{ Volume específico } & + & $0+$ & $0+$ \\
\hline \multicolumn{2}{|l|}{ Dureza } & + & 0 & 0 \\
\hline \multicolumn{5}{|c|}{$\begin{array}{l}\text { - = indica diminuição no valor da resposta; } \\
0 \text { = indica que não houve variação significativa no valor da resposta; } \\
\text { Fonte: Próprio autor, } 2018 .\end{array}$} \\
\hline
\end{tabular}

\subsubsection{Otimização do processo de assamento}

A fim de definir condições de assamento, os binômios tempo e temperatura, que fornecem propriedades físicas semelhantes, optou-se por considerar apenas as respostas perda de água, volume e dureza. Os parâmetros de cor foram considerados apenas como um critério de caracterização dos pães, uma vez que este varia muito de acordo com as preferências individuais do consumidor, além de variar entre diferentes países, como já discutido anteriormente (seção 5.3.2). A resposta altura final do produto não foi utilizada pois os resultados não apresentaram diferença significativa, em sua maioria. Foram selecionados um tempo de assamento para cada temperatura avaliada e realizadas comparações entre os binômios tempo/temperatura e entre os tratamentos com e sem vapor para a mesma condição de tempo/temperatura. Os resultados estão apresentados na Tabela 16. 
Tabela 16 - Condições de assamento (tempo e temperatura) para os tratamentos com (CV) e sem (SV) introdução de vapor, que fornecem respostas semelhantes para volume especifico, dureza e perda de água.

\begin{tabular}{|c|c|c|c|c|}
\hline \multirow{2}{*}{$\begin{array}{l}\text { Propriedades físicas } \\
\text { do pão }\end{array}$} & \multicolumn{4}{|c|}{ Condições de assamento } \\
\hline & Vapor & $160^{\circ} \mathrm{C} / 15 \mathrm{~min}$ & $190^{\circ} \mathrm{C} / 12 \mathrm{~min}$ & $220^{\circ} \mathrm{C} / 9 \mathrm{~min}$ \\
\hline \multirow{2}{*}{ Perda de água (\%) } & $\mathrm{CV}$ & $15,73 \pm 0,59^{\mathrm{bA} 1}$ & $16,34 \pm 0,58^{\mathrm{bA} 1}$ & $14,58 \pm 1,05^{\mathrm{aB} 1}$ \\
\hline & SV & $16,02 \pm 0,43^{\mathrm{aA} 1}$ & $16,12 \pm 0,60^{\mathrm{aA} 1}$ & $16,12 \pm 0,55^{\mathrm{aA} 2}$ \\
\hline \multirow{2}{*}{ Volume especifico (ml/g) } & $\mathrm{CV}$ & $3,13 \pm 0,045^{\mathrm{abAB} 1}$ & $3,00 \pm 0,128^{\mathrm{aAB} 1}$ & $3,25 \pm 0,244^{\mathrm{bBC} 1}$ \\
\hline & SV & $3,53 \pm 0,429^{\mathrm{bC} 2}$ & $2,85 \pm 0,179^{\mathrm{aA} 1}$ & $3,19 \pm 0,233^{\mathrm{abB} 1}$ \\
\hline \multirow{2}{*}{ Dureza (kg) } & $\mathrm{CV}$ & $0,436 \pm 0,055^{\mathrm{aAB} 1}$ & $0,445 \pm 0,090^{\mathrm{aAB} 1}$ & $0,384 \pm 0,033^{\mathrm{aA} 1}$ \\
\hline & SV & $0,406 \pm 0,084^{\mathrm{aAB} 1}$ & $0,496 \pm 0,062^{\mathrm{aB} 1}$ & $0,422 \pm 0,092^{\mathrm{aAB} 1}$ \\
\hline
\end{tabular}

*Letras minúsculas diferentes na mesma linha indicam diferença estatística entre as diferentes condições de tempo/temperatura para uma mesma condição de umidade no forno (com ou sem vapor); **Letras maiúsculas diferentes para uma mesma propriedade física do pão indicam diferença estatística entre as diferentes condições de tempo/temperatura para ambas as condições de umidade (com e sem vapor);

***Números diferentes na mesma coluna para a mesma propriedade física do pão, indicam diferença estatística entre os tratamentos com e sem vapor.

Fonte: Próprio autor, 2019.

Em relação ao parâmetro de perda de água, ao comparar as três condições de tempo/ temperatura $\left(160^{\circ} \mathrm{C} / 15 \mathrm{~min} ; 190^{\circ} \mathrm{C} / 12 \mathrm{~min}\right.$ e $\left.220^{\circ} \mathrm{C} / 9 \mathrm{~min}\right)$ no assamento com vapor a condição $220^{\circ} \mathrm{C} / 9 \mathrm{~min}$ proporcionou maior perda de água enquanto que $160^{\circ} \mathrm{C} / 15 \mathrm{~min}$ e $190^{\circ} \mathrm{C} / 12 \mathrm{~min}$ não diferiram entre si. Para o assamento sem introdução de vapor nenhuma das condições de tempo/temperatura apresentaram diferença estatística. Quanto ao efeito da introdução ou não de vapor em pães assados com a mesma condição de tempo/temperatura apenas $220^{\circ} \mathrm{C} / 9 \mathrm{~min}$ apresentou diferença estatística entre os tratamentos com e sem vapor. Ao comparar todos os tratamentos, ou seja, todas as condições de tempo/temperatura com e sem vapor nota-se que apenas $220^{\circ} \mathrm{C} / 9 \mathrm{~min}$ com vapor apresenta diferença estatística quanto a perda de água.

Analisando os resultados de volume específico em relação aos três tempos/temperaturas, para uma mesma condição de vapor verifica-se que existe uma diferença estatística entre os três binômios (tempo/temperatura). Porém, ao comparar o efeito da introdução ou não de vapor, apenas $160^{\circ} \mathrm{C} / 15$ minutos apresentou diferença entre os tratamentos com e sem vapor. Além disso, a comparação de todos os tratamentos (3 binômios tempo/temperatura em ambas as condições com e sem vapor) demonstra que apenas $160^{\circ} \mathrm{C} / 15$ minutos difere estatisticamente dos outros tratamentos. 
Quanto a dureza, não foi verificado diferença estatística em relação as três condições de tempo/temperatura avaliadas e também em relação a introdução ou não de vapor. Quando comparado todos os tratamentos não foi verificado diferença estatística entre as diferentes condições avaliadas, exceto entre $190^{\circ} \mathrm{C} / 12 \mathrm{~min}$ sem vapor e $220^{\circ} \mathrm{C} / 9 \mathrm{~min}$ com vapor.

Como a maioria das condições de assamento não diferiram entre sim é possível induzir que os pães assados a $160^{\circ} \mathrm{C} / 15 \mathrm{~min} ; 190^{\circ} \mathrm{C} / 12 \mathrm{~min}$ e $220^{\circ} \mathrm{C} / 9 \mathrm{~min}$ com ou sem vapor irão fornecer atributos de perda de água, volume específico e dureza semelhantes. Sendo assim, é possível modificar as condições de processamento do pão mantendo a mesma qualidade. Portanto, é possível produzir um pão de maneira mais rápida $\left(220^{\circ} \mathrm{C} / 9 \mathrm{~min}\right)$ ou com menor gasto energético $\left(160^{\circ} \mathrm{C} / 15 \mathrm{~min}\right)$ e obter a mesma qualidade quanto as propriedades físicas do pão. Logo, a otimizar o processo de produção do pão pode ser alcançada apenas modificando as condições de assamento.

\subsection{Análise do miolo do pão por microscopia eletrônica de varredura (MEV)}

As imagens da microscopia eletrônica de varredura para os pães assados nas diferentes condições de tempo e temperatura sem e com adição de vapor estão apresentadas na Figura 12 para ampliação de 50x e na Figura 13 para ampliação de 1500x.

Com ampliação de 50 vezes (Figura 12) é possível visualizar que, quanto maior o tempo de assamento maior o tamanho dos poros do miolo do pão, além disso os poros também tendem a apresentar uma estrutura mais esférica com o aumento do tempo, este efeito ocorre tanto para os pães assados sem adição de vapor quanto para aqueles que receberam vapor no início do assamento. Em relação as temperaturas de assamento, também observou-se um maior tamanho de poros do miolo dos pães com a elevação da temperatura. Além disso, maiores temperaturas também fornecem maiores taxas de aquecimento, o que pode estar correlacionado com a estrutura dos poros do miolo do pão.

A redução dos poros está relacionada também com a menor capacidade de expansão da massa (BIGNE; C. PUPPO; FERRERO, 2018). A avaliação de microscopia eletrônica de varredura confirma, portanto, o fato de menores tempos de assamento fornecerem menores valores de volumes e dureza, uma vez que os pães apresentam poros menores. 
Figura 12 - Microscopia eletrônica de varredura com ampliação de 50x para os pães assados a 160,190 e $220^{\circ} \mathrm{C}$ durante $9,12,15$ e 20 minutos sem (SV) e com (CV) adição de vapor no início do assamento.

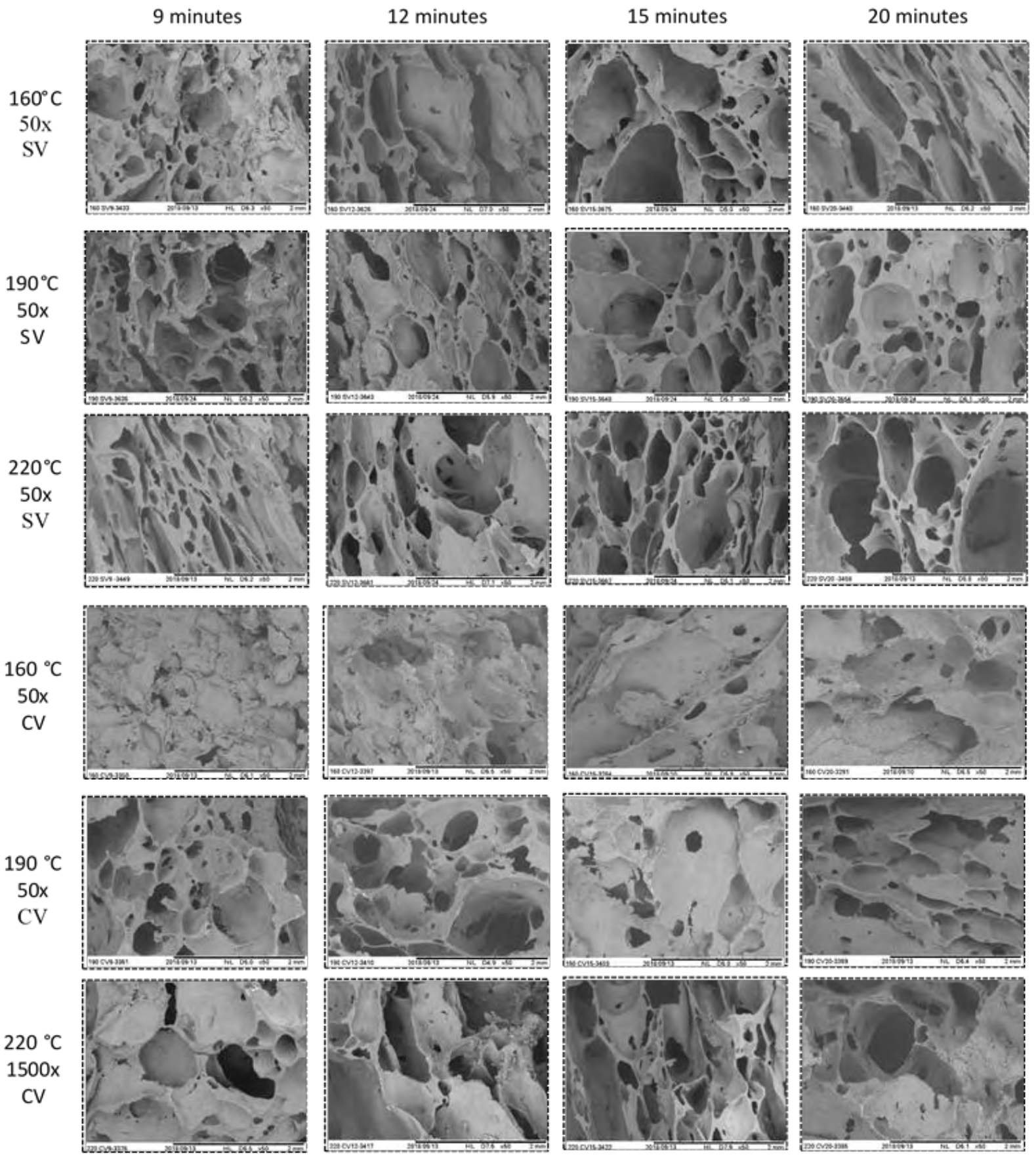

Fonte: Próprio autor, 2019. 
Figura 13 - Microscopia eletrônica de varredura com ampliação de 1500x para os pães assados a 160,190 e $220^{\circ} \mathrm{C}$ durante $9,12,15$ e 20 minutos sem (SV) e com (CV) adição de vapor no início do assamento.

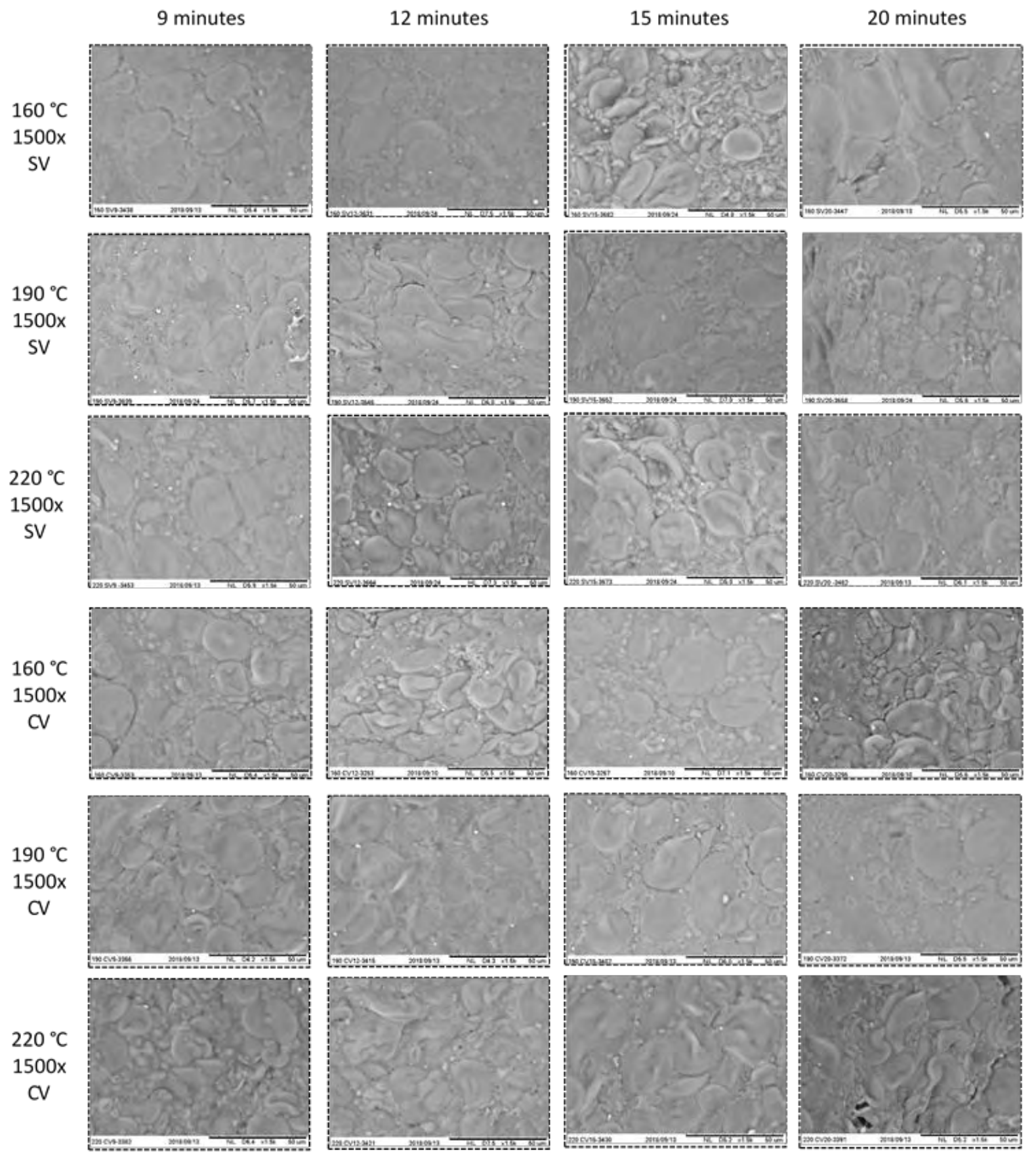

Fonte: Próprio autor, 2019. 
Ao mesmo tempo, pode-se observar que, nas condições de assamento a $160^{\circ} \mathrm{C}$ e $220^{\circ} \mathrm{C}$ sem adição de vapor a estrutura do miolo dos pães apresentam poros não esféricos, mais abertos e aparentemente mais frágil, quando comparado com as outras condições avaliadas. Nesta condição ocorre a aglutinação da estrutura do miolo dos pães e a formação de canais (DATTA et al., 2007) o que irá contribuir com a maior expansão. Por outro lado, o assamento a $190^{\circ} \mathrm{C}$ com e sem adição de vapor forneceu poros com uma estrutura mais consistente com poros mais próximos o que fornece, como consequência, um menor volume.

Com a ampliação de 1500x (Figura 13) é possível ver os grânulos de amido e a matriz proteica. Os grânulos de amido estão distribuídos de maneira aglomerada na microestrutura do pão.

Para o tratamento sem adição de vapor a elevação do tempo e da temperatura de assamento não resultou em mudanças na estrutura do amido. Em geral os grânulos não apresentaram grandes alterações no tamanho e apresentam formato esférico, para todas as condições de tempo e temperatura avaliados. Para o tratamento com vapor, o aumento do tempo de assamento aumentou o tamanho dos grânulos de amido apenas para a temperatura de $190^{\circ} \mathrm{C}$. Quanto a temperatura, um aumento neste parâmetro resultou em uma modificação na estrutura dos grânulos de amido. A $160^{\circ} \mathrm{C}$ ( $\mathrm{t}=9$ e 15 minutos) e a $190^{\circ} \mathrm{C}$ os grânulos apresentaram estrutura esférica, porém, a $220^{\circ} \mathrm{C}$ os grânulos apresentaram forma irregular.

Altamirano-Fortoul et al. (2012) verificaram que o vapor modifica a estrutura dos grânulos de amido, fornecendo uma estrutura menos compacta e esférica, isso ocorre devido ao processo de gelatinização do amido onde ocorre o inchaço dos grânulos na presença de água.

Uma matriz proteica de glúten pode ser vista ao redor dos grânulos de amido para todas as condições avaliadas, assim como também foi verificado por Chong et al. (2017) e Altamirano-Fortoul et al. (2012). Porém, não foi verificado nenhuma modificação em sua estrutura devido as diferentes condições de tempo, temperatura e vapor durante o assamento.

\subsection{Gelatinização dos Grânulos de Amido}

Como visto na seção 5.2, uma taxa de aquecimento específica foi calculada para cada uma das condições de assamento analisadas. A simulação do que ocorre durante a etapa de 
assamento dos pães foi realizada nas análises de DSC, utilizando a massa dos pães logo após finalizar a etapa de mistura dos ingredientes. Durante a análise no DSC não ocorreu a formação da crosta e do miolo, uma vez que o porta amostra é lacrado antes de iniciar a análise no DSC, impedindo assim que ocorra transferência de massa. Porém, a taxa de aquecimento utilizada na análise foi calculada com base no aquecimento que ocorre durante o assamento nas regiões da crosta e do miolo do pão. Logo, as terminologias crosta e miolo foram adotadas neste trabalho.

Com as curvas obtidas durante a elevação da temperatura na análise de DSC foram calculadas duas temperaturas onset (To1 e To2). A Tabela 17 apresenta os resultados da primeira temperatura onset (To1) para cada taxa de aquecimento utilizada. A primeira temperatura onset (To1) variou entre 61,82 a $69,91^{\circ} \mathrm{C}$ e representa a temperatura de gelatinização do amido (Biliaderis et al., 1980, Champenois et al., 1995, Donovan e Regional, 1979). A temperatura de gelatinização do amido está relacionada com taxa de aquecimento, como pode ser visto na Tabela 17, quanto maior a taxa de aquecimento maior a temperatura onset (To1). Ao avaliarmos todas as condições de assamento, na crosta e no miolo dos pães, fica claro o efeito da taxa de aquecimento sobre a temperatura onset (To1). Com o aumento da taxa de aquecimento ocorre a elevação da temperatura onset (To1), sendo que o miolo sem vapor apresentou as menores taxas e consequentemente menores temperaturas (To1), já a crosta sem vapor apresentou as maiores taxas de aquecimento e também as maiores temperaturas onset (To1). 
Tabela 17 - Primeira temperatura onset (To1) para o miolo e para a crosta dos pães em cada taxa de aquecimento avaliada e condição de assamento simulada $\left(160,190\right.$ e $220^{\circ} \mathrm{C}$; sem (SV) e com (CV) introdução de vapor).

\begin{tabular}{lll|lll}
\hline & \multicolumn{2}{c|}{ Miolo } & \multicolumn{3}{c}{ Crosta* $^{*}$} \\
\hline Taxa de & Condição de & Temperatura & Taxa de & \multicolumn{1}{c}{ Condição de } & Temperatura \\
Aquecimento & Assamento & Onset To1 & Aquecimento & Assamento & Onset To1 \\
$\left({ }^{\circ} \mathbf{C} / \mathbf{m i n}\right)$ & Simulada & $\left({ }^{\circ} \mathbf{C}\right)$ & $\left({ }^{\circ} \mathbf{C} / \mathbf{m i n}\right)$ & Simulada & $\left({ }^{\circ} \mathbf{C}\right)$ \\
\hline 8 & $160^{\circ} \mathrm{C}-\mathrm{SV}$ & $61,82 \pm 0,66^{\mathrm{d}}$ & 14 & $160^{\circ} \mathrm{C}-\mathrm{CV}$ & $64,34 \pm 1,74^{\mathrm{c}}$ \\
9 & $190^{\circ} \mathrm{C}-\mathrm{SV}$ & $62,49 \pm 0,57^{\mathrm{cd}}$ & 17 & $190^{\circ} \mathrm{C}-\mathrm{CV}$ & $66,55 \pm 1,57^{\mathrm{b}}$ \\
11 & $220^{\circ} \mathrm{C}-\mathrm{SV}$ & $63,15 \pm 0,49^{\mathrm{cd}}$ & 20 & $220^{\circ} \mathrm{C}-\mathrm{CV}$ & $67,24 \pm 1,14^{\mathrm{b}}$ \\
10 & $160^{\circ} \mathrm{C}-\mathrm{CV}$ & $62,85 \pm 0,97^{\mathrm{cd}}$ & 19 & $160^{\circ} \mathrm{C}-\mathrm{SV}$ & $66,19 \pm 0,41^{\mathrm{b}}$ \\
11 & $190^{\circ} \mathrm{C}-\mathrm{CV}$ & $63,64 \pm 0,98^{\mathrm{cd}}$ & 24 & $190^{\circ} \mathrm{C}-\mathrm{SV}$ & $66,84 \pm 0,48^{\mathrm{b}}$ \\
13 & $220^{\circ} \mathrm{C}-\mathrm{CV}$ & $64,16 \pm 0,39^{\mathrm{c}}$ & 31 & $220^{\circ} \mathrm{C}-\mathrm{SV}$ & $69,91 \pm 1,26^{\mathrm{a}}$ \\
\hline
\end{tabular}

* Neste caso a crosta é representada apenas pela taxa de aquecimento.

** Diferentes letras indicam estatística diferentes entre as diferentes taxas de aquecimento avaliadas. Fonte: Próprio autor, 2019.

Em relação a segunda temperatura de gelatinização (temperatura onset To2), os valores variaram entre 100,77 a $107,90^{\circ} \mathrm{C}$ (Tabela 18), representando a temperatura de fusão dos cristais de amido (Biliaderis et al., 1980, Champenois et al., 1995, Donovan e Regional, 1979). Assim como a temperatura de gelatinização (To1), neste caso também foi verificado uma relação entre a taxa de aquecimento e a temperatura de fusão dos cristais de amido, sendo que, quanto maior a taxa de aquecimento maior foram os valores obtidos para a segunda temperatura onset (To2). Como pode ser visto na Tabela 18, o miolo sem vapor apresentou as menores taxas de aquecimento e as menores temperaturas onset (To2) e a crosta com vapor apresentou as maiores taxas e também as maiores temperaturas onset (To2).

A temperatura de fusão dos cristais de amido (To2) foi obtida através do segundo pico gerado no gráfico durante a análise de DSC. Segundo Fukuoka; Ohta; Watanabe, (2002) e Schirmera; Jekle; Becker (2011) é difícil medir a contribuição do segundo pico para a entalpia, além disso, os resultados podem ser tendenciosos e a contribuição deste pico será pequena. Considerando estes fatores, o cálculo da entalpia de gelatinização foi realizado utilizando apenas a entalpia de gelatinização (To1). 
Tabela 18 - Segunda temperatura onset (To2) para o miolo e para a crosta dos pães em cada taxa de aquecimento avaliada e condição de assamento simulada (160, 190 e $220^{\circ} \mathrm{C}$; sem (SV) e com (CV) introdução de vapor).

\begin{tabular}{|c|c|c|c|c|c|}
\hline \multicolumn{3}{|c|}{ Miolo } & \multicolumn{3}{|c|}{ Crosta* } \\
\hline $\begin{array}{l}\text { Taxa de } \\
\text { Aquecimento } \\
\left({ }^{\circ} \mathrm{C} / \mathrm{min}\right)\end{array}$ & $\begin{array}{l}\text { Condição de } \\
\text { Assamento } \\
\text { Simulada }\end{array}$ & $\begin{array}{l}\text { Temperatura } \\
\text { onset To2 }\left({ }^{\circ} \mathbf{C}\right)\end{array}$ & $\begin{array}{l}\text { Taxa de } \\
\text { Aquecimento } \\
\left({ }^{\circ} \mathrm{C} / \mathrm{min}\right)\end{array}$ & $\begin{array}{l}\text { Condição de } \\
\text { Assamento } \\
\text { Simulada }\end{array}$ & $\begin{array}{l}\text { Temperatura } \\
\text { onset To2 }\left({ }^{\circ} \mathrm{C}\right)\end{array}$ \\
\hline 8 & $160^{\circ} \mathrm{C}-\mathrm{SV}$ & $101,37 \pm 0,94^{\mathrm{def}}$ & 14 & $160^{\circ} \mathrm{C}-\mathrm{CV}$ & $102,02 \pm 0,29^{\text {cdef }}$ \\
\hline 9 & $190^{\circ} \mathrm{C}-\mathrm{SV}$ & $100,83 \pm 0,59^{\mathrm{ef}}$ & 17 & $190^{\circ} \mathrm{C}-\mathrm{CV}$ & $105,22 \pm 0,71^{b}$ \\
\hline 11 & $220^{\circ} \mathrm{C}-\mathrm{SV}$ & $101,17 \pm 0,23^{\mathrm{ef}}$ & 20 & $220^{\circ} \mathrm{C}-\mathrm{CV}$ & $105,38 \pm 1,79^{b}$ \\
\hline 10 & $160^{\circ} \mathrm{C}-\mathrm{CV}$ & $100,77 \pm 0,31^{\mathrm{f}}$ & 19 & $160^{\circ} \mathrm{C}-\mathrm{SV}$ & $103,48 \pm 0,80^{c}$ \\
\hline 11 & $190^{\circ} \mathrm{C}-\mathrm{CV}$ & $103,17 \pm 0,61^{\mathrm{cd}}$ & 24 & $190^{\circ} \mathrm{C}-\mathrm{SV}$ & $105,74 \pm 1,00^{\mathrm{b}}$ \\
\hline 13 & $220^{\circ} \mathrm{C}-\mathrm{CV}$ & $102,38 \pm 0,18^{\text {cde }}$ & 31 & $220^{\circ} \mathrm{C}-\mathrm{SV}$ & $107,90 \pm 2,90^{\mathrm{a}}$ \\
\hline
\end{tabular}

* Neste caso a crosta é representada apenas pela taxa de aquecimento.

** Diferentes letras indicam estatística diferentes entre as diferentes taxas de aquecimento avaliadas.

Fonte: Próprio autor, 2019.

Os valores de entalpia de gelatinização do amido variaram entre 2,65 a 3,66 J/g como apresentado na Tabela 19. Assim como as temperaturas de gelatinização e de fusão dos cristais de amido a entalpia de gelatinização também sofreu influência da taxa de aquecimento, porém, neste caso, quanto maior a taxa de aquecimento menor foi a entalpia de gelatinização.

Tanto as temperaturas (To1 e To2) quanto a entalpia de gelatinização sofreram grande influência da taxa de aquecimento. Como visto na seção 5.2 a água é um fator importante para determinar a taxa de aquecimento durante o assamento. Logo, a quantidade de água presente na amostra irá influenciar nas temperaturas de gelatinização. O presente trabalho apresenta duas temperaturas, To1 próximo a $60^{\circ} \mathrm{C}$ e To 2 próximo a $100^{\circ} \mathrm{C}$, o que representa um sistema com limitado teor de água (Biliaderis et al., 1980, Champenois et al., 1995, Donovan e Regional, 1979). Bosmans et al. (2013) e Rouillé et al. (2010) avaliaram a temperatura de gelatinização do amido em um sistema com excesso de água. Bosmans et al. (2013) obtiveram entalpias maiores para os pães que permaneceram mais tempo armazenado e Rouillé et al. (2010) encontraram valores de temperatura de gelatinização do amido inferiores e entalpia de gelatinização maior as obtidas neste trabalho. Schirmera et al. (2011) encontraram entalpia de gelatinização próximas aos valores obtidos neste trabalho quando avaliaram pães não assados. Todos os outros autores avaliaram pães assados o que pode ter causado redução nas 
temperaturas, uma vez que os pães já haviam passado por um tratamento térmico antes de serem avaliados. Além disso, em ambos os trabalhos, o pão não foi avaliado diretamente após o assamento, o que, de acordo com os resultados obtidos por Bosmans et al. (2013) pode aumentar a entalpia de gelatinização.

Sendo assim, os trabalhos encontrados na literatura não avaliaram exatamente o que ocorre durante o assamento do pão, uma vez que foram utilizadas condições com excesso de água e pães já assados. Entretanto, é necessário compreender os efeitos das condições de assamento sobre as propriedades de gelatinização, uma vez que, cada condição de assamento fornece uma taxa de aquecimento específica e está por sua vez apresenta uma entalpia de gelatinização única.

Tabela 19 - Entalpia de gelatinização do amido para o miolo e para a crosta dos pães em cada taxa de aquecimento avaliada e condição de assamento simulada $\left(160,190\right.$ e $220^{\circ} \mathrm{C}$; sem (SV) e com (CV) introdução de vapor).

\begin{tabular}{|c|c|c|c|c|c|}
\hline \multicolumn{3}{|c|}{ Miolo } & \multicolumn{3}{|c|}{ Crosta* } \\
\hline $\begin{array}{l}\text { Taxa de } \\
\text { Aquecimento } \\
\left({ }^{\circ} \mathrm{C} / \mathrm{min}\right)\end{array}$ & $\begin{array}{l}\text { Condição de } \\
\text { Assamento } \\
\text { Simulada }\end{array}$ & $\begin{array}{l}\text { Entalpia de } \\
\text { Gelatinização } \\
(\mathrm{J} / \mathrm{g})\end{array}$ & $\begin{array}{l}\text { Taxa de } \\
\text { Aquecimento } \\
\left({ }^{\circ} \mathrm{C} / \mathrm{min}\right)\end{array}$ & $\begin{array}{l}\text { Condição de } \\
\text { Assamento } \\
\text { Simulada }\end{array}$ & $\begin{array}{l}\text { Entalpia de } \\
\text { Gelatinização } \\
(\mathrm{J} / \mathrm{g})\end{array}$ \\
\hline 8 & $160^{\circ} \mathrm{C}-\mathrm{SV}$ & $3,66 \pm 0,09^{\mathrm{A}}$ & 14 & $160^{\circ} \mathrm{C}-\mathrm{CV}$ & $3,12 \pm 0,27^{\mathrm{BC}}$ \\
\hline 9 & $190^{\circ} \mathrm{C}-\mathrm{SV}$ & $3,32 \pm 0,15^{\mathrm{AB}}$ & 17 & $190^{\circ} \mathrm{C}-\mathrm{CV}$ & $3,36 \pm 0,03^{\mathrm{AB}}$ \\
\hline 11 & $220^{\circ} \mathrm{C}-\mathrm{SV}$ & $3,34 \pm 0,06^{\mathrm{AB}}$ & 20 & $220^{\circ} \mathrm{C}-\mathrm{CV}$ & $2,69 \pm 0,44^{\mathrm{C}}$ \\
\hline 10 & $160^{\circ} \mathrm{C}-\mathrm{CV}$ & $3,31 \pm 0,13^{\mathrm{AB}}$ & 19 & $160^{\circ} \mathrm{C}-\mathrm{SV}$ & $2,77 \pm 0,17^{\mathrm{C}}$ \\
\hline 11 & $190^{\circ} \mathrm{C}-\mathrm{CV}$ & $3,31 \pm 0,29^{\mathrm{AB}}$ & 24 & $190^{\circ} \mathrm{C}-\mathrm{SV}$ & $2,77 \pm 0,05^{\mathrm{C}}$ \\
\hline 13 & $220^{\circ} \mathrm{C}-\mathrm{CV}$ & $3,00 \pm 0,08^{\mathrm{BC}}$ & 31 & $220^{\circ} \mathrm{C}-\mathrm{SV}$ & $2,65 \pm 0,14^{\mathrm{C}}$ \\
\hline
\end{tabular}

* Neste caso a crosta é representada apenas pela taxa de aquecimento.

** Diferentes letras indicam estatística diferentes entre as diferentes taxas de aquecimento avaliadas.

Fonte: Próprio autor, 2019.

\subsection{Análise da estabilidade dos nutrientes}

\subsection{1. Ácido fólico}

O teor de ácido fólico presente na farinha foi de $403 \pm 54 \mu \mathrm{g}$ ácido fólico/100g amostra, para a massa obtida logo após a mistura dos ingredientes $757 \pm 27 \mu \mathrm{g}$ ácido fólico/100g 
amostra, para a massa depois da fermentação $1043 \pm 60 \mu \mathrm{g}$ ácido fólico/100g amostra (Tabela 20). Para os pães assados os valores variaram entre 1235 e $1598 \mu \mathrm{g}$ ácido fólico/100g amostra, de acordo com as condições de assamento empregadas (Tabela 21). Ocorreu, portanto, um aumento na quantidade de ácido fólico durante a produção, provavelmente, devido ao aquecimento da massa durante a mistura dos ingredientes, na fermentação e no assamento.

Tabela 20 - Ácido fólico ( $\mu$ g ácido fólico/100g amostra) para a farinha de trigo, massa após a mistura dos ingredientes e massa após a fermentação.

\begin{tabular}{lc}
\hline Produto & Ácido fólico $(\boldsymbol{\mu g} / \mathbf{1 0 0 g}$ amostra seca $)$ \\
\hline Farinha & $403 \pm 54^{\mathrm{a}}$ \\
Massa após mistura & $757 \pm 27^{\mathrm{b}}$ \\
Massa após fermentação & $1043 \pm 60^{\mathrm{c}}$
\end{tabular}

*Letras diferentes indicam diferença estatística entre os produtos formados nas diferentes etapas da produção do pão.

Fonte: Próprio autor, 2019.

O teor de ácido fólico encontrado na amostra de farinha está abaixo do valor encontrado para os pães. Outros componentes da formulação do pão podem ter contribuído com o aumento no teor de ácido fólico no produto final. Porém, o valor definido pela ANVISA (2017) para a farinha de trigo é de 140 a $220 \mu \mathrm{g}$ ácido fólico/100g. Sendo assim, os valores encontrados neste trabalho estão acima do exigido pela legislação. BOEN et al., (2007) avaliaram o teor de ácido fólico em pão e também detectaram que 30\% das amostras continham concentrações de ácido fólico acima do exigido pela legislação brasileira.

O conteúdo de ácido fólico presente no pão depende de diversos fatores, como por exemplo, o tipo de pão estudado, a quantidade de farinha adicionada, o teor de água perdida durante o assamento (ANDERSON et al., 2010) o que pode explicar o maior teor de ácido fólico encontrado neste trabalho em relação à literatura.

De maneira geral, o aumento do tempo e temperatura de assamento, assim como o uso ou não de vapor, não provocou variação significativa nos valores de ácido fólico dos pães. 
Tabela 21 - Ácido fólico ( $\mu \mathrm{g}$ ácido fólico/100g amostra) para cada condição de tempo (9, 12,15 e $20 \mathrm{~min}$ ), temperatura $\left(160^{\circ} \mathrm{C}, 190^{\circ} \mathrm{C}\right.$ e $220^{\circ} \mathrm{C}$ ) e introdução (ou não) de vapor durante o assamento dos pães.

\begin{tabular}{lllll}
\hline \multirow{2}{*}{ Temperatura $\left({ }^{\circ} \mathbf{C}\right)$} & \multicolumn{5}{c}{ Tempo (min) } \\
\cline { 2 - 5 } & 9 & 12 & 15 & 20 \\
\hline
\end{tabular}

\begin{tabular}{lcccc}
\hline Sem vapor & & & \\
\hline 160 & $1351 \pm 37^{\mathrm{aA} 1}$ & $1234 \pm 176^{\mathrm{aA} 1}$ & $1598 \pm 8^{\mathrm{bB} 2}$ & $1362 \pm 59^{\mathrm{abAB} 1}$ \\
190 & $1489 \pm 31^{\mathrm{aA} 1}$ & $1478 \pm 22^{\mathrm{aA} 1}$ & $1525 \pm 6^{\mathrm{aB} 2}$ & $1486 \pm 26^{\mathrm{aB} 1}$ \\
220 & $1445 \pm 120^{\mathrm{aA} 1}$ & $1389 \pm 26^{\mathrm{aA} 1}$ & $1303 \pm 44^{\mathrm{aA} 1}$ & $1258 \pm 44^{\mathrm{aA} 1}$ \\
\hline Com vapor & & & \\
\hline 160 & $1358 \pm 102^{\mathrm{aA} 1}$ & $1440 \pm 99^{\mathrm{aA} 1}$ & $1287 \pm 5^{\mathrm{aA} 1}$ & $1391 \pm 109^{\mathrm{aA} 1}$ \\
190 & $1442 \pm 12^{\mathrm{bA} 1}$ & $1480 \pm 21^{\mathrm{cA} 1}$ & $1295 \pm 3^{\mathrm{aA} 1}$ & $1438 \pm 1^{\mathrm{bA} 1}$ \\
220 & $1385 \pm 57^{\mathrm{abA} 1}$ & $1450 \pm 56^{\mathrm{bA} 1}$ & $1301 \pm 24^{\mathrm{aA} 1}$ & $1447 \pm 0^{\mathrm{bA} 2}$ \\
\hline
\end{tabular}

*Letras minúsculas diferentes na mesma linha indicam diferença estatística entre os tempos de assamento para a mesma condição de vapor e temperatura;

**Letras maiúsculas diferentes na mesma coluna indicam diferença estatística entre as diferentes temperaturas de assamento para uma mesma condição de vapor e tempo;

***Números diferentes na mesma coluna para a mesma condição de tempo e temperatura, indicam diferença estatística entre os tratamentos com e sem vapor.

Fonte: Próprio autor, 2018.

Por outro lado, o uso de temperatura elevada $\left(220^{\circ} \mathrm{C}\right)$ por longos período (15 e 20 minutos) provocou redução significativa do teor de ácido fólico das amostras de pães, o que pode sugerir que condições de altas temperaturas e tempos de assamento podem provocar a redução do teor de ácido fólico. Porém, esta hipótese necessitaria ser validada utilizando condições de temperaturas superiores a $220^{\circ} \mathrm{C}$.

As condições de assamento previamente definidas pelas análises de caracterização física, de maneira geral, fornecem pães com os mesmos valores de ácido fólico.

\subsubsection{Minerais}

Na Tabela 22 e 23 estão apresentados os resultados da análise de minerais presentes no pão para cada condição de assamento avaliada. 
Tabela 22 - Teor de macro e microminerais $(\mathrm{mg} / 100 \mathrm{~g}$ de pão liofilizado) encontrados nas amostras de pão francês para cada condição de tempo $(9,12,15$ e $20 \mathrm{~min})$ e temperatura $\left(160,190\right.$ e $\left.220^{\circ} \mathrm{C}\right)$ no assamento sem introdução de vapor.

\begin{tabular}{|c|c|c|c|c|c|c|c|c|c|}
\hline Tratamentos & \multicolumn{5}{|c|}{ Macrominerais (mg/100g de pão liofilizado) } & \multicolumn{4}{|c|}{ Microminerais (mg/100g de pão liofilizado) } \\
\hline em vapor & Fósforo & Potássio & Cálcio & Magnésio & Enxofre & Cobre & Ferro & Manganês & Zinco \\
\hline 160_9 & $162,5 \pm 5,0^{\mathrm{bB} 1}$ & $450,0 \pm 0,0^{\mathrm{bB} 1}$ & $496,7 \pm 5,8^{\mathrm{cC} 1}$ & $110,0 \pm 0,0^{\mathrm{bB} 1}$ & $157,5 \pm 17,1^{\mathrm{bB} 1}$ & $0,4 \pm 0,0^{\mathrm{aA} 1}$ & $3,7 \pm 0,2^{\mathrm{aA} 1}$ & $3,5 \pm 0,0^{\mathrm{aA} 1}$ & $2,6 \pm 0,0^{\mathrm{aA} 1}$ \\
\hline 160_12 & $120 \pm 14,1^{\mathrm{aA} 1}$ & $265,0 \pm 7,1^{\mathrm{aA} 1}$ & $405,0 \pm 7,1^{\mathrm{bC} 1}$ & $65,0 \pm 7,1^{\mathrm{aA} 1}$ & $85,0 \pm 7,1^{\mathrm{aA} 1}$ & $0,5 \pm 0,1^{\mathrm{aA} 1}$ & $3,7 \pm 0,0^{\mathrm{aA} 1}$ & $3,8 \pm 0,6^{\mathrm{aA} 1}$ & $5,6 \pm 1,0^{\mathrm{bA} 1}$ \\
\hline 160_15 & $125,0 \pm 7,1^{\mathrm{aA} 1}$ & $305,0 \pm 35,4^{\mathrm{aA} 1}$ & $380,0 \pm 28,3^{\mathrm{abB} 1}$ & $70,0 \pm 0,0^{\mathrm{aB} 1}$ & $80,0 \pm 14,1^{\mathrm{aA} 1}$ & $0,4 \pm 0,0^{\mathrm{aA} 1}$ & $4,1 \pm 0,0^{\mathrm{bAB} 1}$ & $3,8 \pm 1,0^{\mathrm{aA} 1}$ & $3,8 \pm 1,0^{\mathrm{abA} 1}$ \\
\hline 160_20 & $125,0 \pm 7,1^{\mathrm{aA} 1}$ & $285,0 \pm 21,2^{\mathrm{aB} 1}$ & $360,0 \pm 14,1^{\mathrm{aB} 1}$ & $70,0 \pm 14,1^{\mathrm{aA} 1}$ & $75,0 \pm 21,2^{\mathrm{aA} 1}$ & $0,5 \pm 0,2^{\mathrm{aA} 1}$ & $4,1 \pm 0,1^{\mathrm{bB} 1}$ & $4,3 \pm 0,4^{\mathrm{aB} 1}$ & $3,8 \pm 0,5^{\mathrm{abB} 1}$ \\
\hline 190_9 & $130,0 \pm 0,0^{\mathrm{abA} 1}$ & $290,0 \pm 28,3^{\mathrm{bcA} 1}$ & $305,0 \pm 7,1^{\mathrm{aB} 1}$ & $65,0 \pm 7,1^{\mathrm{aA} 1}$ & $85,0 \pm 21,2^{\mathrm{aA} 1}$ & $0,4 \pm 0,1^{\mathrm{aA} 1}$ & $4,3 \pm 0,2^{\mathrm{aB} 1}$ & $3,7 \pm 0,5^{\mathrm{aA} 1}$ & $3,2 \pm 0,3^{\mathrm{aA} 1}$ \\
\hline 190_12 & $125,0 \pm 7,1^{\mathrm{abA} 1}$ & $245,0 \pm 7,1^{\mathrm{aA} 1}$ & $295,0 \pm 7,1^{\mathrm{aB} 1}$ & $65,0 \pm 7,1^{\mathrm{aA} 1}$ & $120,0 \pm 56,6^{\mathrm{aA} 1}$ & $0,4 \pm 0,0^{\mathrm{aA} 1}$ & $4,3 \pm 0,1^{\mathrm{aB} 1}$ & $4,2 \pm 0,1^{\mathrm{abA} 1}$ & $3,9 \pm 0,9^{\mathrm{aA} 1}$ \\
\hline 190_15 & $120,0 \pm 0,0^{\mathrm{aA} 1}$ & $305,0 \pm 7,1^{\mathrm{cA} 2}$ & $300,0 \pm 14,1^{\mathrm{aA} 1}$ & $70,0 \pm 0,0^{\mathrm{aB} 2}$ & $145,0 \pm 21,2^{\mathrm{aB} 1}$ & $0,5 \pm 0,1^{\mathrm{aA} 1}$ & $4,3 \pm 0,2^{\mathrm{aB} 1}$ & $4,7 \pm 0,4^{\mathrm{bA} 1}$ & $4,5 \pm 0,1^{\mathrm{aA} 1}$ \\
\hline 190_20 & $135,0 \pm 7,1^{\mathrm{bA} 1}$ & $255 \pm 7,1^{\mathrm{abA} 1}$ & $305,0 \pm 7,1^{\mathrm{aA} 1}$ & $70,0 \pm 14,1^{\mathrm{aA} 1}$ & $125,0 \pm 7,1^{\mathrm{aB} 1}$ & $0,4 \pm 0,0^{\mathrm{aA} 1}$ & $4,2 \pm 0,1^{\mathrm{aB} 2}$ & $4,7 \pm 0,1^{\mathrm{bB} 2}$ & $4,3 \pm 0,2^{\mathrm{aB} 1}$ \\
\hline 220_9 & $125,0 \pm 7,1^{\mathrm{aA} 1}$ & $255,0 \pm 21,2^{\mathrm{aA} 1}$ & $275,0 \pm 7,1^{\mathrm{aA} 1}$ & $70,0 \pm 0,0 b^{\mathrm{cA} 1}$ & $65,0 \pm 7,1^{\mathrm{aA} 1}$ & $0,4 \pm 0,0^{\mathrm{bA} 2}$ & $3,7 \pm 0,1^{\mathrm{aA} 1}$ & $4,9 \pm 0,6^{\mathrm{bB} 1}$ & $2,6 \pm 0,3^{\mathrm{aA} 1}$ \\
\hline 220_12 & $120,0 \pm 14,1^{\mathrm{aA} 1}$ & $255,0 \pm 7,1^{\mathrm{aA} 1}$ & $270,0 \pm 0,0^{\mathrm{aA} 1}$ & $65,0 \pm 7,1^{\mathrm{bA} 1}$ & $70,0 \pm 14,1^{\mathrm{abA} 1}$ & $0,4 \pm 0,0^{\mathrm{bA} 1}$ & $3,8 \pm 0,0^{\mathrm{aA} 1}$ & $4,4 \pm 0,1^{\mathrm{bA} 1}$ & $3,9 \pm 0,8^{\mathrm{abA} 1}$ \\
\hline 220_15 & $115,0 \pm 7,1^{\mathrm{aA} 1}$ & $250,0 \pm 0,0^{\mathrm{aA} 1}$ & $255,0 \pm 21,2^{\mathrm{aA} 1}$ & $50,0 \pm 0,0^{\mathrm{aA} 1}$ & $95,0 \pm 7,1^{\mathrm{bA} 1}$ & $0,4 \pm 0,0^{\mathrm{bA} 1}$ & $3,9 \pm 0,0^{\mathrm{aA} 1}$ & $4,7 \pm 0,2^{\mathrm{bA} 1}$ & $4,8 \pm 1,5^{\mathrm{bA} 1}$ \\
\hline 220_20 & $155,0 \pm 5,8^{\mathrm{bB} 1}$ & $540,0 \pm 0,0^{\mathrm{bB} 2}$ & $490,0 \pm 14,1^{\mathrm{bC} 2}$ & $112,5 \pm 9,6^{\mathrm{bB} 2}$ & $165,0 \pm 19,1^{\mathrm{bB} 2}$ & $0,2 \pm 0,0^{\mathrm{aA} 1}$ & $4,0 \pm 0,2^{\mathrm{aA} 1}$ & $4,1 \pm 1,1^{\mathrm{aA} 1}$ & $2,3 \pm 0,2^{\mathrm{aA} 1}$ \\
\hline
\end{tabular}

*Letras minúsculas diferentes na mesma coluna indicam diferença estatística entre os tempos de assamento para a mesma condição de temperatura e vapor;

**Letras maiúsculas diferentes na mesma coluna indicam diferença estatística entre as diferentes temperaturas de assamento para uma mesma condição de tempo e vapor;

***Números diferentes na mesma coluna para a mesma condição de tempo e temperatura, indicam diferença estatística entre os tratamentos com e sem vapor.

Fonte: Próprio autor, 2018. 
Tabela 23 - Teor de macro e microminerais $(\mathrm{mg} / 100 \mathrm{~g}$ de pão liofilizado) encontrados nas amostras de pão francês para cada condição de tempo $(9,12,15$ e $20 \mathrm{~min})$ e temperatura $\left(160,190\right.$ e $\left.220^{\circ} \mathrm{C}\right)$ no assamento com introdução de vapor.

\begin{tabular}{|c|c|c|c|c|c|c|c|c|c|}
\hline Tratamentos & \multicolumn{5}{|c|}{ Macrominerais (mg/100g de pão liofilizado) } & \multicolumn{4}{|c|}{ Microminerais (mg/100g de pão liofilizado) } \\
\hline Com vapor & Fósforo & Potássio & Cálcio & Magnésio & Enxofre & Cobre & Ferro & Manganês & Zinco \\
\hline 160_9 & $170,0 \pm 16,3^{\mathrm{bB} 1}$ & $450,0 \pm 0,0^{\mathrm{cC} 1}$ & $587,5 \pm 15,0^{\mathrm{cC} 2}$ & $120,0 \pm 8,2^{\mathrm{bB} 2}$ & $165,0 \pm 12,9^{\mathrm{cB} 1}$ & $0,3 \pm 0,0^{\mathrm{aA} 1}$ & $4,3 \pm 0,1^{\mathrm{bB} 2}$ & $3,4 \pm 0,1^{\mathrm{aA} 1}$ & $2,4 \pm 0,5^{\mathrm{aA} 1}$ \\
\hline 160_12 & $130,0 \pm 0,0^{\mathrm{aA} 1}$ & $315,0 \pm 21,2^{\mathrm{bA} 1}$ & $530,0 \pm 14,1^{\mathrm{bB} 2}$ & $80,0 \pm 0,0^{\mathrm{aA} 1}$ & $110,0 \pm 0,0^{\mathrm{bA} 2}$ & $0,6 \pm 0,2^{\mathrm{aA} 1}$ & $3,7 \pm 0,1^{\mathrm{aA} 1}$ & $3,2 \pm 0,5^{\mathrm{aA} 1}$ & $4,1 \pm 0,1^{\mathrm{bB} 1}$ \\
\hline 160_15 & $125,0 \pm 7,1^{\mathrm{aA} 1}$ & $260,0 \pm 14,1^{\mathrm{aA} 1}$ & $485,0 \pm 35,4^{\mathrm{abB} 1}$ & $75,0 \pm 7,1^{\mathrm{aB} 1}$ & $80,0 \pm 14,1^{\mathrm{aA} 1}$ & $0,4 \pm 0,1^{\mathrm{aA} 1}$ & $4,2 \pm 0,1^{\mathrm{bB} 1}$ & $3,3 \pm 0,4^{\mathrm{aA} 1}$ & $4,2 \pm 0,6^{\mathrm{bAB} 1}$ \\
\hline 160_20 & $125,0 \pm 7,1^{\mathrm{aA} 1}$ & $300,0 \pm 14,1^{\mathrm{bA} 1}$ & $440,0 \pm 14,1^{\mathrm{aB} 1}$ & $70,0 \pm 0,0^{\mathrm{aA} 1}$ & $80,0 \pm 14,1^{\mathrm{aA} 1}$ & $0,4 \pm 0,0^{\mathrm{a} A \mathrm{~B} 1}$ & $3,9 \pm 0,1^{\mathrm{aA} 1}$ & $3,3 \pm 0,2^{\mathrm{aA} 1}$ & $4,5 \pm 0,1^{\mathrm{bB} 1}$ \\
\hline 190_9 & $130,0 \pm 0,0^{\mathrm{aA} 1}$ & $245,0 \pm 7,1^{\mathrm{aA} 1}$ & $350,0 \pm 14,1^{\mathrm{bB} 1}$ & $75,0 \pm 7,1^{\mathrm{bA} 1}$ & $80,0 \pm 0,0^{\mathrm{aA} 1}$ & $0,4 \pm 0,0^{\mathrm{aA} 1}$ & $4,2 \pm 0,0^{\mathrm{aB} 1}$ & $4,8 \pm 0,3^{\mathrm{aC} 1}$ & $4,6 \pm 0,1^{\mathrm{aB} 2}$ \\
\hline 190_12 & $130,0 \pm 0,0^{\mathrm{aA} 1}$ & $275,0 \pm 7,1^{\mathrm{bA} 1}$ & $340,0 \pm 0,0^{\mathrm{bA} 2}$ & $70,0 \pm 0,0^{\mathrm{abA} 1}$ & $100,0 \pm 14,1^{\mathrm{abA} 1}$ & $0,4 \pm 0,0^{\mathrm{aA} 1}$ & $4,3 \pm 0,1^{\mathrm{aB} 1}$ & $4,8 \pm 0,6^{\mathrm{aA} 1}$ & $4,8 \pm 0,5^{\mathrm{aB} 1}$ \\
\hline 190_15 & $125,0 \pm 7,1^{\mathrm{aA} 1}$ & $255,0 \pm 7,1^{\mathrm{aA} 1}$ & $310,0 \pm 0,0^{\mathrm{aA} 1}$ & $60,0 \pm 0,0^{\mathrm{aA} 1}$ & $90,0 \pm 0,0^{\mathrm{abA} 1}$ & $0,4 \pm 0,1^{\mathrm{aA} 1}$ & $4,6 \pm 0,1^{\mathrm{bC} 1}$ & $4,8 \pm 0,2^{\mathrm{aB} 1}$ & $4,9 \pm 0,7^{\mathrm{aB} 1}$ \\
\hline 190_20 & $130,0 \pm 0,0^{\mathrm{aA} 1}$ & $295,0 \pm 7,1^{\mathrm{cA} 2}$ & $305,0 \pm 7,1^{\mathrm{aA} 1}$ & $65,0 \pm 7,1^{\mathrm{abA} 1}$ & $110,0 \pm 14,1^{\mathrm{bA} 1}$ & $0,5 \pm 0,3^{\mathrm{aB} 1}$ & $4,2 \pm 0,0^{\mathrm{aA} 1}$ & $4,2 \pm 0,1^{\mathrm{aA} 1}$ & $3,7 \pm 0,9^{\mathrm{aB} 1}$ \\
\hline 220_9 & $130,0 \pm 14,1^{\mathrm{aA} 1}$ & $295,0 \pm 21,2^{\mathrm{bB} 1}$ & $295,0 \pm 7,1^{\mathrm{aA} 1}$ & $70,0 \pm 0,0^{\mathrm{aA} 1}$ & $70,0 \pm 14,1^{\mathrm{aA} 1}$ & $0,3 \pm 0,0^{\mathrm{bA} 1}$ & $3,8 \pm 0,0^{\mathrm{aA} 1}$ & $3,9 \pm 0,0^{\mathrm{aB} 1}$ & $2,8 \pm 0,7^{\mathrm{aA} 1}$ \\
\hline 220_12 & $125,0 \pm 7,1^{\mathrm{aA} 1}$ & $280,0 \pm 28,3^{\mathrm{abA} 1}$ & $290,0 \pm 28,3^{\mathrm{aA} 1}$ & $75,0 \pm 7,1^{\mathrm{aA} 1}$ & $85,0 \pm 7,1^{\mathrm{aA} 1}$ & $0,4 \pm 0,0^{\mathrm{cA} 1}$ & $3,9 \pm 0,1^{\mathrm{aA} 1}$ & $4,6 \pm 0,4^{\mathrm{aA} 1}$ & $2,4 \pm 0,0^{\mathrm{aA} 1}$ \\
\hline 220_15 & $120,0 \pm 0,0^{\mathrm{aA} 1}$ & $250,0 \pm 0,0^{\mathrm{aA} 1}$ & $270,0 \pm 0,0^{\mathrm{aA} 1}$ & $70,0 \pm 0,0^{\mathrm{aB} 2}$ & $65,0 \pm 7,1^{\mathrm{aA} 1}$ & $0,4 \pm 0,0^{\mathrm{bcA} 1}$ & $3,8 \pm 0,1^{\mathrm{aA} 1}$ & $4,5 \pm 0,3^{\mathrm{aB} 1}$ & $2,5 \pm 0,0^{\mathrm{aA} 1}$ \\
\hline 220_20 & $150,0 \pm 0,0^{\mathrm{bB} 1}$ & $450,0 \pm 0,0^{\mathrm{bC} 1}$ & $323,3 \pm 5,8^{\mathrm{bA} 1}$ & $77,5 \pm 5,0^{\mathrm{bA} 1}$ & $160,0 \pm 14,1^{\mathrm{cC} 1}$ & $0,3 \pm 0,0^{\mathrm{aA} 1}$ & $3,9 \pm 0,1^{\mathrm{aA} 1}$ & $3,6 \pm 0,0^{\mathrm{aA} 1}$ & $2,7 \pm 0,3^{\mathrm{aA} 1}$ \\
\hline
\end{tabular}

*Letras minúsculas diferentes na mesma coluna indicam diferença estatística entre os tempos de assamento para a mesma condição de temperatura e vapor;

**Letras maiúsculas diferentes na mesma coluna indicam diferença estatística entre as diferentes temperaturas de assamento para uma mesma condição de tempo e vapor;

***Números diferentes na mesma coluna para a mesma condição de tempo e temperatura, indicam diferença estatística entre os tratamentos com e sem vapor.

Fonte: Próprio autor, 2018. 
Em relação aos macrominerais $(\mathrm{mg} / 100 \mathrm{~g})$, fósforo $(\mathrm{P})$, potássio $(\mathrm{K})$, cálcio $(\mathrm{Ca})$, magnésio (Mg), enxofre (S), estes variaram entre, 115,0 e 170,0, 245,0 e 540,0, 255,0 e 587,5, 50,0 e 120,0, e 65,0 e 165,0, respectivamente. Os microminerais (mg/100g), cobre $(\mathrm{Cu})$, ferro (Fe), manganês (Mn) e zinco (Zn), variaram entre 0,2 e 0,6, 3,7 e 4,6, 3,2 e 4,9, e 2,3 e 5,6, respectivamente. Outros autores também avaliaram o conteúdo de minerais de pães (CHINMA et al., 2016; IZASKUNGARCÍA-MANTRANA; VICENTEMONEDERO; MONIKAHAROS, 2015; LAMACCHIA et al., 2018; NOORT et al., 2017; TUNCEL et al., 2014; WRONKOWSKA et al., 2015). Os resultados encontrados neste trabalho estão dentro dos valores encontrados na literatura, com exceção do cálcio e manganês, os quais apresentaram maiores valores em relação aos observados na literatura. Os trabalhos encontrados na literatura também diferem entre si no conteúdo de minerais, possivelmente devido às diferenças em relação aos ingredientes utilizados e as condições de processamento adotadas (FRONTELA; ROS; MARTÍNEZ, 2011).

O aumento do tempo de assamento apresentou efeito significativo no teor de macrominerais, tanto para o tratamento com vapor quanto para o tratamento sem adição de vapor, porém este depende da temperatura utilizada no assamento. Quando os pães foram assados a $220^{\circ} \mathrm{C}$ o teor dos macrominerais, de maneira geral, apresentou aumento significativo em função do aumento do tempo de assamento. Por outro lado, para a temperatura de assamento de $160^{\circ} \mathrm{C}$ o teor de macrominerais apresentou redução significativa em função do aumento do tempo de assamento. Para os microminerais, de maneira geral, não foi observado efeito significativo em função do aumento do tempo de assamento.

Em relação ao aumento da temperatura de assamento, de maneira geral, tanto os macro quanto os microminerais, apresentaram redução significativa.

Em relação à adição ou não de vapor, a maioria dos macrominerais tendem a permanecer constante com o tempo. Para algumas condições de assamento alguns macrominerais aumentam com a adição de vapor, como é o caso do Cálcio, Enxofre, Ferro e Zinco. Já o Potássio e Magnésio podem aumentar ou reduzir dependendo das condições de tempo e temperatura avaliadas. No caso dos microminerais, alguns apresentaram efeito significativo em relação à adição ou não de vapor. O Cobre é reduzido pela adição de vapor quando o assamento é realizado a $220^{\circ} \mathrm{C}$ por 9 minutos e o Manganês em assamento a $190^{\circ} \mathrm{C}$ por 20 minutos. O Ferro pode tanto reduzir, manter-se constante ou aumentar com a adição de vapor, dependendo da condição de tempo e temperatura utilizada. Por fim, o teor de Zinco aumenta com a adição de vapor, quando o pão é assado a $190^{\circ} \mathrm{C}$ por 9 minutos. 
Sendo assim, em geral, o uso de temperaturas mais baixas, tendem a fornecer pães com maior teor de macro e micronutrientes. Neste caso, a condição a $220^{\circ} \mathrm{C}$ por 9 minutos, a qual apresenta melhor resposta em relação às propriedades tecnológicas, não fornecerá uma boa resposta em termos de composição de minerais. As demais condições com boas respostas para as propriedades tecnológicas estão adequadas com as respostas obtidas nesta seção.

\subsubsection{Oxalato}

Os resultados de oxalato estão apresentados na Tabela 24 em função das condições de assamento dos pães. O teor de oxalato na farinha foi de $34,9 \pm 1,5 \mathrm{mg} / 100 \mathrm{~g}$ de extrato e no pão variou entre 30,4 a 44,0 mg/100 g de extrato. Os valores estão próximos aos encontrados por Abdualrahman et al. (2016), entre 32 a 78 mg/100 g de extrato e Kumar et al. (2017), entre 25,8 e $119,5 \mathrm{mg} / 100 \mathrm{~g}$ de extrato.

O teor de oxalato presente no pão apresentou redução em função do aumento do tempo e temperatura de assamento. A introdução ou não de vapor teve pouco efeito sobre o teor de oxalato.

Quanto maior o tempo de assamento menores foram os valores de oxalato encontrados na amostra para praticamente todas as condições avaliadas, com exceção do assamento realizado a $220^{\circ} \mathrm{C}$ sem vapor, que não apresentou diferença estatística entre os diferentes tempos.

Em relação ao efeito da temperatura, para o tratamento sem introdução de vapor, o aumento da temperatura resultou em um decréscimo no teor de oxalato presente nos pães. Porém, para o assamento realizado com adição de vapor este efeito foi menos expressivo. Apenas os pães assados por 9 minutos apresentaram redução do oxalato com a elevação da temperatura, sendo que, para os demais tempos não foi verificado variação significativa no teor de oxalato.

O efeito da adição ou não de vapor também foi pouco significativo, apenas os pães submetidos ao tratamento a $190^{\circ} \mathrm{C}$ por 15 e 20 minutos apresentaram redução no teor de oxalato com a adição de vapor. As demais condições não apresentaram diferença significativa entre os tratamentos com e sem vapor.

Kumar et al. (2017) avaliaram fatias de taro submetidas a três tratamentos térmicos (cozimento com água fervente, com solução de limão e sob vapor em panela de pressão) antes da secagem e produção das farinhas. Foi constatado uma redução no teor de oxalato com o 
aumento do tempo, o que está de acordo com os resultados obtidos neste estudo. Os tratamentos que tiveram contato direto com o meio (água e solução de limão) apresentara maior perda de oxalato, o que, segundo Kumar et al. (2017) pode ter ocorrido devido a perdas por lixiviação de oxalatos solúveis, porém, o tratamento em panela de pressão, em que as fatias de taro não entraram em contato direto com o meio, também apresentou redução com o aumento do tempo, o que indica que o oxalato pode ser sensível ao efeito da temperatura.

Tabela 24 - Oxalato $(\mathrm{mg} / 100 \mathrm{~g}$ de extrato) para cada condição de tempo $(9,12,15$ e 20 $\min$ ), temperatura $\left(160,190\right.$ e $220^{\circ} \mathrm{C}$ ) e introdução (ou não) de vapor durante o assamento dos pães.

\begin{tabular}{lllll}
\hline & \multicolumn{5}{c}{ Tempo (min) } \\
\hline
\end{tabular}

\begin{tabular}{lllll}
\hline Sem vapor & & & \\
\hline 160 & $42,5 \pm 0,0^{\mathrm{bC} 1}$ & $39,5 \pm 0,0^{\mathrm{aB} 1}$ & $37,5 \pm 2,3^{\mathrm{aA} 1}$ & $36,4 \pm 0,0^{\mathrm{aB} 1}$ \\
190 & $38,0 \pm 0,0^{\mathrm{bB} 1}$ & $37,5 \pm 0,9^{\mathrm{abB} 1}$ & $37,5 \pm 0,9^{\mathrm{abA}}{ }^{\mathrm{a}}$ & $35,4 \pm 1,8^{\mathrm{aB} 2}$ \\
220 & $35,7 \pm 1,1^{\mathrm{bA} 1}$ & $35,7 \pm 1,1^{\mathrm{bA} 1}$ & $33,9 \pm 1,8^{\mathrm{abA} 1}$ & $30,4 \pm 2,1^{\mathrm{aA} 1}$ \\
\hline Com vapor & & & \\
\hline 160 & $44,0 \pm 2,1^{\mathrm{bB} 1}$ & $37,5 \pm 2,3^{\mathrm{aA} 1}$ & $34,4 \pm 0,9^{\mathrm{aA} 1}$ & $31,9 \pm 4,3^{\mathrm{aA} 1}$ \\
190 & $37,5 \pm 1,8^{\mathrm{cA} 1}$ & $35,9 \pm 0,9^{\mathrm{bcA} 1}$ & $34,4 \pm 0,9^{\mathrm{bA} 1}$ & $31,9 \pm 0,0^{\mathrm{aA} 1}$ \\
220 & $34,9 \pm 0,0^{\mathrm{aA} 1}$ & $34,2 \pm 1,1^{\mathrm{aA} 1}$ & $33,9 \pm 0,9^{\mathrm{aA} 1}$ & $31,9 \pm 2,1^{\mathrm{aA} 1}$ \\
\hline
\end{tabular}

*Letras minúsculas diferentes na mesma linha indicam diferença estatística entre os tempos de assamento para a mesma condição de vapor e temperatura;

**Letras maiúsculas diferentes na mesma coluna indicam diferença estatística entre as diferentes temperaturas de assamento para uma mesma condição de vapor e tempo;

***Números diferentes na mesma coluna para a mesma condição de tempo e temperatura, indicam diferença estatística entre os tratamentos com e sem vapor.

Fonte: Próprio autor, 2018.

O oxalato é um antinutriente que pode impedir a disponibilidade do ferro e do zinco (LEAL et al., 2010). É aconselhável, portanto, utilizar temperaturas e tempos de assamento mais elevados, a fim de degradar o conteúdo de oxalato presente no pão. Os melhores tempos de assamento, neste caso seriam, por pelo menos 12 minutos a $160^{\circ} \mathrm{C}$ e $190^{\circ} \mathrm{C}$ para ambas as condições de vapor, e no mínimo 15 minutos a $220^{\circ} \mathrm{C}$ sem vapor, já para a condição a $220^{\circ} \mathrm{C}$ com vapor, todos os tempos são aceitáveis. As condições previamente definidas pelas análises de caracterização física dos pães $\left(160^{\circ} \mathrm{C} / 15 \mathrm{~min} ; 190^{\circ} \mathrm{C} / 12 \mathrm{~min}\right.$ e $\left.220^{\circ} \mathrm{C} / 9 \mathrm{~min}\right)$ apresentaram os menores teores de oxalato, com exceção do tratamento a $220^{\circ} \mathrm{C}$ sem adição de vapor, neste caso, será necessário optar ou pelas condições físicas do pão ou pelo teor de oxalato. 


\subsubsection{Digestibilidade relativa da proteína}

Os resultados de digestibilidade proteica, expressos em termo de $\alpha$ L-leucina equivalente (LE) das amostras de pães, para cada condição de assamento, e para o controle (pão não assado) estão apresentados na Tabela 25. A digestibilidade relativa da proteína para as amostras de pães assadas variou entre 49 a 160\%. Comparando os resultados dos pães assados sob diferentes condições de tempo, temperatura e vapor com os pães antes do assamento verifica-se que todas as condições testadas apresentaram digestibilidade estatisticamente superior ou igual aos pães não assados.

Tabela 25 - Digestibilidade relativa da proteína (\%) para cada condição de tempo $(9,12,15$ e $20 \mathrm{~min}$ ), temperatura $\left(160^{\circ} \mathrm{C}, 190^{\circ} \mathrm{C}\right.$ e $220^{\circ} \mathrm{C}$ ) e introdução (ou não) de vapor durante o assamento dos pães.

\section{Temperatura Tempo (min)}

$\left({ }^{\circ} \mathbf{C}\right)$

$$
0 \quad 9
$$

12

15

20

Sem Vapor

\begin{tabular}{llllll}
\hline 160 & $100^{\mathrm{bc}}$ & $97,24 \pm 7,17^{\mathrm{cB} 2}$ & $133,38 \pm 20,00^{\mathrm{aA} 1}$ & $123,21 \pm 13,27^{\mathrm{ab} 1}$ & $125,47 \pm 15,26^{\mathrm{abA} 1}$ \\
190 & $100^{\mathrm{ab}}$ & $129,49 \pm 16,55^{\mathrm{aA} 1}$ & $129,36 \pm 14,37^{\mathrm{aA} 1}$ & $122,58 \pm 22,41^{\mathrm{aA} 1}$ & $89,21 \pm 14,52^{\mathrm{bAB} 1}$ \\
220 & $100^{\mathrm{ab}}$ & $120,08 \pm 7,26^{\mathrm{aA} 1}$ & $98,87 \pm 4,49^{\mathrm{abB} 2}$ & $105,40 \pm 48,30^{\mathrm{abA} 1}$ & $63,49 \pm 23,92^{\mathrm{bB} 1}$ \\
\hline
\end{tabular}

Com Vapor

\begin{tabular}{llllll}
\hline 160 & $100^{\mathrm{a}}$ & $130,43 \pm 11,98^{\mathrm{aA} 1}$ & $118,82 \pm 29,07^{\mathrm{aA} 1}$ & $108,53 \pm 15,43^{\mathrm{aA} 1}$ & $123,71 \pm 7,93^{\mathrm{aA} 1}$ \\
190 & $100^{\mathrm{a}}$ & $90,46 \pm 5,08^{\mathrm{aB} 2}$ & $127,35 \pm 22,00^{\mathrm{aA} 1}$ & $118,44 \pm 15,33^{\mathrm{aA} 1}$ & $106,27 \pm 34,53^{\mathrm{aA} 1}$ \\
220 & $100^{\mathrm{b}}$ & $129,49 \pm 2,94^{\mathrm{aA} 1}$ & $133,00 \pm 13,83^{\mathrm{aA} 1}$ & $133,50 \pm 25,00^{\mathrm{aA} 1}$ & $96,86 \pm 8,62^{\mathrm{bA} 1}$ \\
\hline
\end{tabular}

*Letras minúsculas diferentes na mesma linha indicam diferença estatística entre os tempos de assamento para a mesma condição de vapor e temperatura;

**Letras maiúsculas diferentes na mesma coluna indicam diferença estatística entre as diferentes temperaturas de assamento para uma mesma condição de vapor e tempo;

***Números diferentes na mesma coluna para a mesma condição de tempo e temperatura, indicam diferença estatística entre os tratamentos com e sem vapor.

Fonte: Próprio autor, 2019.

De maneira geral, o aumento do tempo de assamento provocou redução significativa na digestibilidade relativa da proteína.

Quanto à elevação da temperatura observou-se que para o assamento por 12 e 20 minutos sem introdução de vapor, ocorreu uma redução na digestibilidade da proteína. Os pães assados com introdução de vapor não sofreram alteração da digestibilidade com a 
elevação da temperatura. Ou seja, é possível evitar a redução da digestibilidade proteica através do uso do vapor.

Em relação a introdução, ou não de vapor, de maneira geral, não foram observadas variações significativas.

Swieca et al. (2017) avaliaram a digestibilidade da proteína na farinha de trigo e em pães assados e também constataram um aumento na digestibilidade para os produtos assados. Segundo Abdel-Aal (2008) o processo de assamento aumenta a digestibilidade da proteína, uma vez que ele deixa as proteínas mais acessíveis a ação das enzimas. Além disso, a combinação de diferentes técnica de processo e condições de assamento também podem impedir a perda da digestibilidade (GULATI et al., 2018).

A qualidade nutricional das proteínas está relacionada com os peptídeos de cadeia curta formados durante o processo de digestão (KETNAWA; OGAWA, 2019). A hidrólise da proteína irá formar peptídeos e aminoácidos, que por sua vez irão contribuir para deixar o nitrato mais disponível (THÉRON et al., 2018). Portanto, um aumento na digestibilidade implicará em um aumento na qualidade proteica (KETNAWA; OGAWA, 2019). Logo, é desejado trabalhar em condições de assamento que forneçam maior digestão da proteína.

Objetivando obter as melhores condições de digestibilidade, deve-se, portanto, introduzir vapor no assamento, ou quando não for possível, deve-se optar por temperaturas mais baixas $\left(160^{\circ} \mathrm{C}\right)$ ou tempo de assamento reduzidos.

Os tempos de assamento que melhor preservam a digestibilidade proteica no pão são de pelo menos 12 minutos para o tratamento a $160^{\circ} \mathrm{C}$ sem introdução de vapor e de no máximo 15 minutos para $190^{\circ} \mathrm{C}$ sem vapor e $220^{\circ} \mathrm{C}$ com e sem introdução de vapor. Os demais tratamentos apresentaram digestibilidade constante com o aumento do tempo de assamento, logo, todos os tempos podem ser utilizados. Sendo assim, as melhores condições de tempo e temperatura para a digestibilidade proteica estão de acordo com as selecionadas pela avaliação tecnológica.

\subsubsection{Resumo dos efeitos}

A Tabela 26 apresenta um resumo dos efeitos das condições de assamento (tempo, temperatura e introdução ou não de vapor) sobre a estabilidade dos nutrientes. 
O aumento de tempo de assamento exerceu influência sobre a estabilidade dos nutrientes, reduzindo o teor dos macrominerais dos pães assados a $160^{\circ} \mathrm{C}$ e também reduzindo o conteúdo de oxalato e a digestibilidade relativa das proteínas. Porém, não exerceu efeito significativo sobre o conteúdo de ácido fólico nos pães.

Em relação ao efeito da temperatura, tanto os minerais (macro e micro), quanto o teor de oxalato e a digestibilidade relativa das proteínas reduziram com a elevação da temperatura. Já o acido fólico não sofreu influencia da elevação da temperatura.

Em relação a introdução de vapor, foi apresentado efeito significativo apenas sobre alguns microminerais, mesmo assim, não foi verificado uma resposta igual para todos os microminerais, sendo que alguns componentes (cobre e manganês) apresentaram menor conteúdo no tratamento que recebeu vapor, enquanto que o zinco apresentou maior conteúdo. As demais respostas não apresentaram efeito significativo em relação a adição ou não de vapor.

Tabela 26 - Efeito do tempo, temperatura e umidade no forno sobre as respostas de ácido fólico, macro e microminerais, oxalato e digestibilidade relativa da proteína nos pães.

\begin{tabular}{lccc}
\hline \multirow{2}{*}{ Resposta } & \multicolumn{3}{c}{ Aumento } \\
\cline { 2 - 4 } & Tempo & Temperatura & Vapor \\
\hline Ácido fólico & 0 & 0 & 0 \\
\hline Macrominerais & $-\left(160^{\circ} \mathrm{C}\right) /+\left(220^{\circ} \mathrm{C}\right)$ & - & $-(\mathrm{Cu} ; \mathrm{Mn}) /+$ ou- $(\mathrm{Fe}) /+(\mathrm{Zn})$ \\
\hline Microminerais & 0 & - & 0 \\
\hline Oxalato & - & - & 0 \\
\hline $\begin{array}{l}\text { Digestibilidade } \\
\text { relativa da proteína }\end{array}$ & - & $-(\mathrm{SV}) / 0(\mathrm{CV})$ & \\
\hline
\end{tabular}

$*+=$ indica aumento no valor da resposta;

- = indica diminuição no valor da resposta;

0 = indica que não houve variação significativa no valor da resposta;

Cobre (Cu), Manganês (Mn), Ferro (Fe) e Zinco ( $\mathrm{Zn})$;

Fonte: Próprio autor, 2019.

Portanto, é possível reduzir as perdas de minerais e o teor de oxalato assim como melhorar a digestibilidade relativa das proteínas através do controle das condições de tempo e temperatura durante o assamento dos pães. 


\section{CONCLUSÕES}

As propriedades tecnológicas do pão francês e a estabilidade dos compostos com valor nutricional ou antinutricional foram avaliadas em pães produzidos sob diferentes condições de tempo $\left(9,12,15\right.$ e 20 minutos), temperatura $\left(160{ }^{\circ} \mathrm{C}, 190^{\circ} \mathrm{C}\right.$ e $\left.220^{\circ} \mathrm{C}\right)$ e presença ou não de vapor no forno. Foi constatado que a estrutura dos pães em nível microscópico sofre influência das condições de assamento e contribui com a expansão da massa e textura do pão. Existem condições de assamento que contribuíram para melhorar as propriedades tecnológicas dos pães. Além disso, também é possível modificar a produção dos pães utilizando as diferentes combinações de tempo e temperatura durante o assamento, a fim de aumentar a capacidade produtiva ou reduzir o gasto de processo, sem modificar a qualidade do produto final.

Já as propriedades relacionadas a gelatinização do amido dependem da taxa de aquecimento e são únicas para cada condição de assamento.

Quanto a qualidade nutricional, a digestibilidade relativa da proteína pode ser preservada pelo controle das condições de assamento. O pão também possui ácido fólico, minerais e oxalato. Não foi observado uma relação entre degradação de ácido fólico devido ao aumento do tempo, temperatura ou presença de vapor durante o assamento, porém, é possível preservar alguns minerais ou reduzir o teor de oxalato controlando as condições de assamento, sendo possível, com isso, obter pães com maior valor nutricional.

Este trabalho, pode, portanto, ser utilizado por industrias da área de panificação, como referência na seleção das melhores condições de assamento, de acordo com suas necessidades tanto em termos tecnológicos quanto em relação as propriedades nutricionais. Cabe, porém, a industria selecionar as condições que melhor se adéquam com suas necessidades, uma vez que, não foi encontrado uma condição de tempo, temperatura e introdução ou não de vapor durante o assamento que melhore todas as propriedades físicas e nutricionais do pão. Além disso, a qualidade do pão em termos de cor, volume e dureza é subjetiva, não sendo possível estabelecer um padrão ideal que agrade todos os consumidores de pão. Logo, apenas a industria, conhecendo seu publico alvo e suas preferências em termos de propriedades físicas poderá definir quais aspectos deseja fornecer ao seu pão e assim selecionar, de acordo com resultados obtidos neste trabalho, qual as melhores condições de tempo, temperatura e se deseja ou não introduzir vapor durante o assamento. 


\section{REFERÊNCIAS}

ABDEL-AAL, E. S. M. Effects of baking on protein digestibility of organic spelt products determined by two in vitro digestion methods. LWT - Food Science and Technology, v. 41, p. 1282-1288, 2008.

ABDUALRAHMAN, M. A. Y. et al. Nutritional value, protein quality and antioxidant activity of Sudanese sorghum-based kissra bread fortified with bambara groundnut (Voandzeia subterranea) seed flour. Journal of the Saudi Society of Agricultural Sciences, 2017.

ABIP, A. B. DA I. DE P. E C. Estudo do impacto da inovação tecnológica no setor de panificação e confeitaria. [s.l: s.n.].

ABIP, A. B. DA I. DE P. E C. A descoberta do pão (pré-história) - CENA I. Disponível em: <http://www.abip.org.br/perfil_internas.aspx?cod=418>. Acesso em: 9 jul. 2014.

ABIP, A. B. DA I. DE P. E C. Indicadores 2016: Desempenho de empresas de panificação e confeitaria brasileiras em 2016.

ABNT, A. B. DE N. T.; SEBRAE, S. B. DE A. ÀS M. E P. E. Guia de implementação pão tipo francês: Diretrizes para avaliação da qualidade e classificaçã. Rio de Janeiro: [s.n.].

ADLER-NISSEN, J. Determination of the degree of hydrolysis of food protein hydrolysates by trinitrobenzenesulfonic acid. Journal of agricultural and food chemistry, v. 27, n. 6, p. 1256-1262, 1979.

AHRNÉ, L. et al. Effect of crust temperature and water content on acrylamide formation during baking of white bread: Steam and falling temperature baking. LWT - Food Science and Technology, v. 40, p. 1708-1715, 2007.

ALABURDA, J.; SHUNDO, L. Ácido fólico e fortificação de alimentos. Revista Instituto Adolfo Lutz, v. 66, p. 95-102, 2007.

ALTAMIRANO-FORTOUL, R. et al. Effect of the amount of steam during baking on bread crust features and water diffusion. Journal of Food Engineering, v. 108, n. 1, p. 128-134, 2012.

AMENDOLA, J.; REES, N. Understanding Baking: The art and science of baking. 3. ed. Londres: John Wiley Trade, 2003.

ANDERSON, W. A. et al. Reduction of folic acid during baking and implications for mandatory fortification of bread. International Journal of Food Science and Technology, v. 45, p. 1104-1110, 2010.

ANDREWS, N. C. Disorders of iron metabolism. The New England Journal of Medicine Review, v. 341, n. 26, p. 1986-1995, 1999.

ANTONIEWSKA, A. et al. Antioxidative, nutritional and sensory properties of mu ffi ns with buckwheat flakes and amaranth flour blend partially substituting for wheat flour. LWT Food Science and Technology, v. 89, p. 217-223, 2018.

ANVISA, A. N. DE V. S. Resolução - RDC n 150, de 13 de abril de 2017. Diário Oficial da União, v. 73, p. 37, 17 abr. 2017.

AOAC. Official Methods of Analysis. 12. ed. Washington: Association of Official 
Analytical Chemists, 1980.

AOAC. Official methods of analysis of AOAC International. 16. ed. [s.1.] AOAC International, 1995.

AOCS. Official methods and recommended practices of the AOCS. 6. ed. [s.l: s.n.].

BACCAN, N. et al. Química analítica quantitativa elementar. $3^{\text {a }}$ edição ed. Campinas: [s.n.].

BALUZ, K.; CARMO, M. DAS G. T. DO; ROSAS, G. O papel do ácido fólico na prevenção e na terapêutica oncológica : revisão. Revista Brasileira de Cancerologia, v. 48, n. 4, p. 597-607, 2002.

BARBOSA-RÍOS, J. A. et al. Effect of new generation enzymes addition on the physical , viscoelastic and textural properties of traditional Mexican sweet bread. Journal of Cereal Science, v. 79, p. 160-167, 2018.

BÁRCENAS, M. E.; ROSELL, C. M. Effect of HPMC addition on the microstructure, quality and aging of wheat bread. Food Hydrocolloids, v. 19, p. 1037-1043, 2005.

BERTRAND, E. et al. The Maillard Reaction in Food : An Introduction. In: Elsevier. [s.l: s.n.]. p. 1-10.

BESBES, E. et al. Water vapor transport properties during staling of bread crumb and crust as affected by heating rate. Food Research International, v. 50, p. 10-19, 2013.

BIGNE, F.; C. PUPPO, M.; FERRERO, C. Mesquite (Prosopis alba) flour as a novel ingredient for obtaining a "panettone-like" bread. Applicability of part-baking technology.

LWT - Food Science and Technology, v. 89, p. 666-673, 2018.

BILIADERIS, C. G.; MAURICE, T. J.; VOSE, J. R. Starch gelatinization phenomena studied differential scanning calorimetry. Journal of Food Science, v. 45, p. 1669-1674, 1980.

BOEN, T. R. et al. Avaliação do teor de ferro e zinco e composição centesimal de farinhas de trigo e milho enriquecidas. Revista Brasileira de Ciências Farmacêuticas, v. 43, n. 4, p. 589-596, 2007.

BOSMANS, G. M. et al. The impact of baking time and bread storage temperature on bread crumb properties. Food Chemistry, v. 141, p. 3301-3308, 2013.

BRESSIANI, J. et al. Properties of whole grain wheat flour and performance in bakery products as a function of particle size. Journal of Cereal Science, v. 75, p. 269-277, 2017.

BUENO, A. L.; CZEPIELEWSKI, M. A. Micronutrientes envolvidos no crescimento. Revista do Hospital das Clínicas de Porto Alegre, v. 27, n. 3, p. 47-56, 2007.

BULDINI, P. L.; CAVALLI, S.; TRIFIRO, A. State-of-the-art ion chromatographic determination of inorganic ions in food. Journal of Chromatography A, v. 789, p. 529-548, 1997.

CAPRILES, V. D.; GUERRA-MATIAS, A. C.; ARÊAS, J. A. G. Marcador in vitro da resposta glicêmica dos alimentos como ferramenta de auxílio à prescrição e avaliação de dietas. Revista de Nutricão, v. 22, n. 4, p. 549-557, 2009.

CHAMPENOIS, Y. et al. Starch gelatinisation and gelation in white pan bread. Sciences des Aliments, v. 15, p. 593-614, 1995. 
CHEN, G. et al. Physicochemical properties and gluten structures of hard wheat flour doughs as affected by salt. Food Chemistry, v. 275, p. 569-576, 2019.

CHHANWAL, N. et al. Computational fluid dynamics ( CFD ) modeling of an electrical heating oven for bread-baking process. Journal of Food Engineering, v. 100, p. 452-460, 2010 .

CHINMA, C. E. et al. Effect of acha and bambara nut sourdough flour addition on the quality of breadLWT - Food Science and Technology, 2016.

CHONG, H. M. et al. Mechanical and microstructural changes of cheese cracker dough during bakingLWT - Food Science and Technology, 2017.

COZZOLINO, S. M. F. Deficiências de Minerais. Estudos Avançados, v. 21, n. 60, p. 119126, 2007.

CZEIZEL, A. E.; DUDÁS, I. Prevention of the first occurrence of neural-tube defects by preconceptual vitamin supplementation. The New England Journal of Medicine, v. 327, n. 26, p. 1832-1835, 1992.

DATTA, A. K. et al. Porous media characterization of breads baked using novel heating modes. Journal of Food Engineering, v. 79, p. 106-116, 2007.

DEBONNE, E. et al. Impact of par-baking and storage conditions on the quality of par-baked and fully baked bread. LWT - Food Science and Technology, v. 78, p. 16-22, 2017.

DONOVAN, J. W. Phase transitions of the starch-water system. Biopolymers, v. 18, p. 263$275,1979$.

ERBAS, M. et al. Effect of sodium metabisulfite addition and baking temperature on maillard reaction in bread. Journal of Food Quality, v. 35, p. 144-151, 2012.

FEITOSA, L. R. G. DE F. et al. Avaliação de qualidade do pão tipo francês por métodos instrumentais e sensoriais Evaluation of quality of bread type french by instrumental and sensory methods. Semina: Ciências Agrárias, v. 34, n. 2, p. 693-704, 2013.

FESSAS, D.; SCHIRALDI, A. Starch gelatinization kinetics in bread dough. DSC investigations on 'simulated' baking processes. Journal of Thermal Analysis and Calorimetry, v. 61, p. 411-423, 2000.

FIDELIS, C. M. F.; OSÓRIO, M. M. Consumo alimentar de macro e micronutrientes de crianças menores de cinco anos no Estado de Pernambuco, Brasil. Revista Brasileira de Saúde Materna e infantil, v. 7, n. 1, p. 63-74, 2007.

FRAKOLAKI, G. et al. Chemical characterization and breadmaking potential of spelt versus wheat flour. Journal of Cereal Science, v. 79, p. 50-56, 2018.

FRONTELA, C.; ROS, G.; MARTÍNEZ, C. Phytic acid content and "in vitro" iron, calcium and zinc bioavailability in bakery products: The effect of processing. Journal of Cereal Science, v. 54, n. 1, p. 173-179, 2011.

FU, Z. et al. Effect of (-)-epigallocatechin gallate (EGCG) extracted from green tea in reducing the formation of acrylamide during the bread baking process. Food Chemistry, v. 242, p. 162-168, 2018.

FUKUOKA, M.; OHTA, K.; WATANABE, H. Determination of the terminal extent of starch gelatinization in a limited water system by DSC. Journal of Food Engineering, v. 53, p. 39- 
42, 2002.

GALLY, T. et al. Bread baking using ohmic heating technology; a comprehensive study based on experiments and modelling. Journal of Food Engineering, v. 190, p. 176-184, 2016.

GISSLEN, W. Professional baking. 4. ed. Paris: John Wiley \& Sons, Inc., 1895.

GRENIER, D.; RAY, D. LE; LUCAS, T. Combining local pressure and temperature measurements during bread baking: insights into crust properties and alveolar structure of crumb. Journal of Cereal Science, v. 52, p. 1-8, 2010.

GUADARRAMA-LEZAMA, A. Y. et al. Rheological and thermal properties of dough and textural and microstructural features of bread obtained from nixtamalized corn/wheat flour blends. Journal of Cereal Science, v. 69, p. 158-165, 2016.

GUJSKA, E.; MAJEWSKA, K. Effect of baking process on added folic acid and endogenous folates stability in wheat and rye breads. Plant Foods for Human Nutrition, v. 60, p. 37-42, 2005.

GULATI, P.; SABILLÓN, L.; ROSE, D. J. Effects of processing method and solute interactions on pepsin digestibility of cooked proso millet flour. Food Research International, v. 109, p. 583-588, 2018.

GUPTA, V.; NAGAR, R. Minerals and antinutrients profile of rabadi after different traditional preparation methods. Journal of Food Science and Technology, v. 51, n. 8, p. 1617-1621, 2014.

INSTITUTO TECNOLÓGICO DE PANIFICAÇÃO E CONFEITARIA (ITPC). Indicadores do Setor: Performance do setor de panificação e confeitaria brasileiro em 2016.

Disponível em: <https://institutoitpc.jimdo.com/indicadores-do-setor/>. Acesso em: 15 set. 2017.

IZADI NAJAFABADI, L. et al. Impact of baking conditions and storage temperature on staling of fully and part-baked Sangak bread. Journal of Cereal Science, v. 60, n. 1, p. 151$156,2014$.

IZASKUNGARCÍA-MANTRANA; VICENTEMONEDERO; MONIKAHAROS. Myoinositol hexakisphosphate degradation by Bifidobacterium pseudocatenulatum ATCC 27919 improves mineral availability of high fibre rye-wheat sour bread. Food Chemistry, v. 178, p. 267-275, 2015.

IZZREEN, M. N. N. Q.; HANSEN, Å. S.; PETERSEN, M. A. Volatile compounds in whole meal bread crust : The effects of yeast level and fermentation temperature. Food Chemistry, v. 210 , p. 566-576, 2016.

JAFARI, M.; KOOCHEKI, A.; MILANI, E. Effect of extrusion cooking of sorghum flour on rheology, morphology and heating rate of sorghum-wheat composite dough. Journal of Cereal Science, v. 77, p. 49-57, 2017.

KEETELS, C. J. A. M.; OOSTERGETEL, G. T.; VAN VLIET, T. Recrystallization of amylopectin in concentrated starch gels. Carbohydrate Polymers, v. 30, n. 1, p. 61-64, 1996.

KENNEFICK, S.; CASHMAN, K. D. Investigation of in vitro model for predicting the effect of food components on calcium availability from meals. International Journal of Food 
Science and Nutrition, v. 51, p. 45-54, 2000.

KETNAWA, S.; OGAWA, Y. Evaluation of protein digestibility of fermented soybeans and changes in biochemical characteristics of digested fractions. Journal of Functional Foods, v. 52, p. 640-647, 2019.

KIM, B.-K. et al. Effect of microparticulated wheat bran on the physical properties of bread. International journal of food sciences and nutrition, v. 64, n. 1, p. 122-129, 2013.

KŁOBUKOWSKI1, J. A.; SKIBNIEWSKA2, K. A.; KOWALSKI, I. M. Calcium bioavailability from dairy products and its release from food by in vitro digestion. Journal of Elementology, n. March, p. 277-288, 2014.

KUMAR, V.; SHARMA, H. K.; SINGH, K. Effect of precooking on drying kinetics of taro (Colocasia esculenta) slices and quality of its flours. Food Bioscience, v. 20, p. 178-186, 2017.

LAMACCHIA, C. et al. Temperature-treated gluten proteins in Gluten-Friendly ${ }^{\mathrm{TM}}$ bread increase mucus production and gut-barrier function in human intestinal goblet cells. Journal of Functional Foods, v. 48, p. 507-514, 2018.

LARA, E. et al. Structural and physical modifications of corn biscuits during baking process. LWT - Food Science and Technology, v. 44, p. 622-630, 2011.

LE-BAIL, A. et al. Energy demand for selected bread making processes: Conventional versus part baked frozen technologies. Journal of Food Engineering, v. 96, p. 510-519, 2010.

LE-BAIL, A. et al. Influence of the amount of steaming during baking on the kinetic of heating and on selected quality attributes of bread. Journal of Food Engineering, v. 105, p. 379-385, 2011.

LEAL, A. S. et al. Avaliação da concentração de minerais e dos fatores antinutricionais fitato e oxalato em multimisturas da Região Metropolitana de Belo Horizonte/MG. Sociedade Brasileira de Alimentos e Nutrição, v. 35, n. 2, p. 39-52, 2010.

LIU, S. et al. Enterococcus faecium as a Salmonella surrogate in the thermal processing of wheat flour: Influence of water activity at high temperatures. Food Microbiology, v. 74, p. 92-99, 2018.

LUND, D.; LORENZ, K. J. Influence of time , temperature , moisture , ingredients , and processing conditions on starch gelatinization. C R C Critical Reviews in Food Science and Nutrition, v. 20, n. 4, p. 249-273, 1984.

LUO, D. et al. Effects of ultrasound assisted dough fermentation on the quality of steamed bread. Journal of Cereal Science, v. 83, p. 147-152, 2018.

MAIHARA, V. A. et al. Avaliação nutricional de dietas de trabalhadores em relação a proteínas, lipídeos, carboidratos, fibras alimentares e vitaminas. Ciências e Tecnologia de Alimentos, v. 26, n. 3, p. 672-677, 2006.

MALUMBA, P. et al. The swelling behaviour of wheat starch granules during isothermal and non-isothermal treatments. Journal of Food Engineering, v. 114, p. 199-206, 2013.

MARGARET I. B. DICK, I. T. H. A. K. T. H. F. THE THERMAL STABILITY OF FOLIC ( PTEROYLGLUTAMJC ) ACID. p. 6, 1947.

MARTI, A. et al. Flour from sprouted wheat as a new ingredient in bread-making. LWT - 
Food Science and Technology, v. 89, p. 237-243, 2018.

MILDNER-SZKUDLARZ, S. et al. Phenolic compounds reduce formation of Ne(carboxymethyl)lysine and pyrazines formed by Maillard reactions in a model bread system. Food Chemistry, v. 231, p. 175-184, 2017.

MINISTÉRIO DA SAÚDE. Resolução de Diretoria Colegiada - RDC No 344, de 13 de dezembro de 2002Diário Oficial da União, 2002.

MONDAL, A.; DATTA, A. K. Bread baking - A review. Journal of Food Engineering, v. 86, p. 465-474, 2008.

MONDAL, A.; DATTA, A. K. Investigation of the process parameters using response surface methodology on the quality of crustless bread baked in a water-spraying oven. Journal of Food Process Engineering, v. 34, p. 1819-1837, 2011.

MURPHY, K. M.; REEVES, P. G.; JONES, S. S. Relationship between yield and mineral nutrient concentrations in historical and modern spring wheat cultivars. Euphytica, v. 163, p. 381-390, 2008.

NEILL, G.; AL-MUHTASEB, A. H.; MAGEE, T. R. . Optimisation of time / temperature treatment , for heat treated soft wheat flour. Journal of Food Engineering, v. 113, p. 422426, 2012.

NEPA - NÚCLEO DE ESTUDOS E PESQUISAS EM ALIMENTAÇÃO. Tabela brasileira de composição de alimentos - TACO. UNICAMP, v. 4, p. 161 p., 2011.

NOGUEIRA, A. R. DE A.; SOUZA, G. B. DE. Manual de laboratórios: Solo, água, nutrição vegetal, nutrição animal e alimentos. 3. ed. São Carlos: Embrapa, 2005.

NOORT, M. W. J. et al. HealthBread: Wholegrain and high fibre breads with optimised textural qualityJournal of Cereal Science, 2017.

O'BRIEN, J.; MORRISSEY, P. A.; AMES, J. M. Nutritional and toxicological aspects of the Maillard browning reaction in foods. Critical Reviews in Food Science and Nutrition, v. 28, n. 3, p. 211-248, 1989.

OKOMBO, J.; LIEBMAN, M. Oxalate content of selected breads and crackers. Journal of Food Composition and Analysis, v. 23, p. 118-121, 2010.

OLAERTS, H.; VANDEKERCKHOVE, L.; COURTIN, C. M. A closer look at the bread making process and the quality of bread as a function of the degree of preharvest sprouting of wheat ( Triticum aestivum ). Journal of Cereal Science, v. 80, p. 188-197, 2018.

OSSEYI, E. S.; WEHLING, R. L.; ALBRECHT, J. A. HPLC determination of stability and distribution of added folic acid and some endogenous folates during breadmaking. Cereal Chemistry, v. 78, n. 4, p. 375-378, 2001.

ÖZKAYA, B.; BAUMGARTNER, B.; ÖZKAYA, H. Effects of concentrated and dephytinized wheat bran and rice bran addition on bread properties. Journal of Texture Studies, v. 49, n. 1, p. 84-93, 2018.

PACYNSKI, M.; WOJTASIAK, R. Z.; MILDNER-SZKUDLARZ, S. Improving the aroma of gluten-free bread. LWT - Food Science and Technology, v. 63, p. 706-713, 2015.

PARK, C. S.; BAIK, B. K. Influences of baking and thawing conditions on quality of parbaked French bread. Cereal Chemistry, v. 84, n. 1, p. 38-43, 2007. 
PASRIJA, D. et al. Microencapsulation of green tea polyphenols and its effect on incorporated bread quality. LWT - Food Science and Technology, v. 64, n. 1, p. 289-296, 2015.

PASTORIZA, S.; QUESADA, J.; RUFIAN-HENARE, J. Lactose and oligosaccharides: Maillard reaction. In: Elsevier. Granada: Elsevier Inc., 2018. p. 1-19.

PATRIGNANI, M. et al. Antioxidant capacity of Maillard reaction products in the digestive tract : An in vitro and in vivo study. Food Chemistry, v. 276, p. 443-450, 2019.

PÉREZ-BURILLO, S.; RUFIÁN-HENARE, J. Á.; PASTORIZA, S. Effect of home cooking on the antioxidant capacity of vegetables: Relationship with Maillard reaction indicators.

Food Research International, 2018.

PÉTEL, C.; ONNO, B.; PROST, C. Sourdough volatile compounds and their contribution to bread: A review. Trends in Food Science \& Technology, v. 59, p. 105-123, 2017.

PICO, J. et al. Evolution of volatile compounds in gluten-free bread: From dough to crumb. Food Chemistry, v. 227, p. 179-186, 2017.

PICO, J.; BERNAL, J.; GÓMEZ, M. Wheat bread aroma compounds in crumb and crust : A review. Food Research International, v. 75, p. 200-215, 2015.

PURLIS, E. Bread baking: Technological considerations based on process modelling and simulation. Journal of Food Engineering, v. 103, n. 1, p. 92-102, 2011.

PYLER, E. J; GORTON, L. A. Banking science \& technology. 4. ed. Kansas City: Sosland Publishing CO., 2008.

RATNAYAKE, W. S.; OTANI, C.; JACKSON, D. S. DSC enthalpic transitions during starch gelatinisation in excess water, dilute sodium chloride and dilute sucrose solutions. Journal of the Science of Food and Agriculture, v. 89, p. 2156-2164, 2009.

REBELLATO, A. P. et al. Mineral bioaccessibility in French breads fortified with different forms iron and its effects on rheological and technological parameters. Journal of Cereal Science, v. 74, p. 56-63, 2017.

ROSANOFF, A. Changing crop magnesium concentrations: Impact on human health. Plant and Soil, v. 368, p. 139-153, 2013.

ROUILLÉ, J. et al. Dough/crumb transition during French bread baking. Journal of Cereal Science, v. 52, p. 161-169, 2010.

SAINI, P. et al. Physicochemical, functional and biscuit making properties of wheat flour and potato flour blends. Current Nutrition \& Food Science, v. 13, p. 1-6, 2017.

SALOVAARA, H. Effect of partial sodium chloride replacement by other salts on wheat dough rheology and breadmaking. Cereal chemistry, v. 59, n. 5, p. 422-426, 1982.

SANTOS, L. M. P.; PEREIRA, M. Z. Efeito da fortificação com ácido fólico na redução dos defeitos do tubo neural. Cadernos de Saúde Pública, v. 23, n. 1, p. 17-24, 2007.

SCHEUER, P. M. et al. Effects of fat replacement on properties of whole wheat bread.

Brazilian Journal of Pharmaceutical Sciences, v. 50, n. 4, p. 703-712, 2014.

SCHIRMERA, M.; JEKLE, M.; BECKER, T. Quantification in starch microstructure as a function of baking time. Procedia Food Science, v. 1, p. 145-152, 2011. 
SCHMIELE, M. et al. Mixolab ${ }^{\mathrm{TM}}$ for rheological evaluation of wheat flour partially replaced by soy protein hydrolysate and fructooligosaccharides for bread production. LWT - Food

Science and Technology, v. 76, p. 259-269, 2017.

SȨCZYK, Ł.; STWIECA, M.; GAWLIK-DZIKI, U. Effect of carob (Ceratonia siliqua L.) flour on the antioxidant potential, nutritional quality, and sensory characteristics of fortified durum wheat pasta. Food Chemistry, v. 194, p. 637-642, 2016.

SHEN, Y.; CHEN, G.; LI, Y. Bread characteristics and antioxidant activities of Maillard reaction products of white pan bread containing various sugars. LWT - Food Science and Technology, v. 95, p. 308-315, 2018.

SHITTU, T. A.; RAJI, A. O.; SANNI, L. O. Bread from composite cassava-wheat flour: I. Effect of baking time and temperature on some physical properties of bread loaf. Food Research International, v. 40, p. 280-290, 2007.

SLIWINSKI, E. L.; KOLSTER, P.; VAN VLIET, T. On the relationship between largedeformation properties of wheat flour dough and baking quality. Journal of Cereal Science, v. 39, p. 231-245, 2004.

SOTELO, A. et al. Role of oxate, phytate, tannins and cooking on iron bioavailability from foods commonly consumed in Mexico. International journal of food sciences and nutrition, v. 61, n. 1, p. 29-39, 2010.

SOUZA, R. C. R.; ANDRADE, C. T. Investigação dos processos de gelatinização e extrusão de amido de milho. Polímeros: Ciência e Tecnologia, v. 10, n. 1, p. 24-30, 2000.

SUI, X.; YAP, P. Y.; ZHOU, W. Anthocyanins during baking: their degradation kinetics and impacts on color and antioxidant capacity of bread. Food and Bioprocess Technology, v. 8, p. 983-994, 2015.

SWIECA, M.; DZIKI, D.; GAWLIK-DZIKI, U. Starch and protein analysis of wheat bread enriched with phenolics-rich sprouted wheat flour. Food Chemistry, v. 228, p. 643-648, 2017.

TAVARES, W. P. S. et al. Effect of different cooking conditions on the profiles of Maillard reaction products and nutrient composition of hairtail (Thichiurus lepturus) fillets. Food Research International, v. 103, p. 390-397, 2018.

TEBBEN, L.; SHEN, Y.; LI, Y. Improvers and functional ingredients in whole wheat bread: A review of their e ff ects on dough properties and bread quality. Trends in Food Science $\&$ Technology, v. 81, p. 10-24, 2018.

THÉRON, L. et al. To what extent does the nitrosation of meat proteins influence their digestibility? Food Research International, v. 113, p. 175-182, 2018.

TUNCEL, N. B. et al. The effect of infrared stabilized rice bran substitution on B vitamins, minerals and phytic acid content of pan breads: Part II. Journal of Cereal Science, v. 59, p. 162-166, 2014.

VANIN, F. M. et al. Simulating the formation of bread crust in a DMTA rheometer. Journal of Cereal Science, v. 51, p. 277-283, 2010.

VANIN, F. M. et al. Water loss and crust formation during bread baking, Part II: Technological insights from a sensitivity analysis of a numerical model of baking. Drying Technology, v. 35, n. 12, p. 1518-1529, 2017. 
VASAFI, P. S.; HAMDAMI, N.; KERAMAT, J. Quality and microbial stability of part-baked "Barbari bread" during freezing storage. LWT - Food Science and Technology, v. 104, p. 173-179, 2019.

VASCONCELOS, A. C. DE et al. Processamento e aceitabilidade de pães de forma a partir de ingredientes funcionais: Farinha de soja e fibra alimentar. Alimentos e Nutrição

Araraquara, v. 17, n. 1, p. 43-49, 2006.

VERBAUWHEDE, A. E. et al. Thermo-reversible inhibition makes aqualysin 1 from Thermus aquaticus a potent tool for studying the contribution of the wheat gluten network to the crumb texture of fresh bread. Food Chemistry, v. 264, p. 118-125, 2018.

VERHEYEN, C. et al. Impact of gas formation kinetics on dough development and bread quality. Food Research International, v. 76, p. 860-866, 2015.

VIDAL, A. et al. Enzyme bread improvers affect the stability of deoxynivalenol and deoxynivalenol-3-glucoside during breadmaking. Food Chemistry, v. 208, p. 288-296, 2016.

VOURIS, D. G. et al. Wheat bread quality attributes using jet milling flour fractions. LWT Food Science and Technology, 2018.

WAGNER, M. J. et al. Water transport in bread during baking. Journal of Food Engineering, v. 78, p. 1167-1173, 2007.

WAGNER, M. J. et al. MRI study of bread baking: Experimental device and MRI signal analysis. International Journal of Food Science and Technology, v. 43, p. 1129-1139, 2008.

WALD, N. et al. Quantifying the effect of folic acid. The Lancet, v. 358, p. 2069-2073, 2001.

WALSH, C. T. et al. Zinc: Health Effects and Research Priorities for the 1990s. Environmental Health Perspectives, v. 102, p. 5-46, 1994.

WOLEVER, T. M. S. et al. The glycemic index: methodology and clinical implications. The American Journal of Clinical Nutrition, v. 54, p. 846-854, 1991.

WRONKOWSKA, M. et al. ACID whey concentrated by ultrafiltration a tool for modeling bread propertiesLWT - Food Science and Technology, 2015.

ZANONI, B.; PERI, C.; BRUNO, D. Modelling of browning kinetics of bread crust during baking. LWT - Food Science and Technology, v. 28, n. 6, p. 604-609, 1995.

ZANONI, B.; SCHIRALDI, A.; SIMONETTA, R. A Naive Model of Starch Gelatinization Kinetics. Journal of Food Engineering, v. 24, p. 25-33, 1995.

ZHANG, L. et al. Thermal inactivation kinetics of $\beta$-galactosidase during bread baking. Food Chemistry, v. 225, p. 107-113, 2017a.

ZHANG, L. et al. Water loss and crust formation during bread baking, Part I: Interpretation aided by mathematical models with highlights on the role of local porosity. Drying Technology, v. 35, n. 12, p. 1506-1517, 2017 b. 